Illinois State University

ISU ReD: Research and eData

Theses and Dissertations

$10-1-2020$

\title{
Black While Leading: Unmasking The Anti-Black Lived Experiences Of Senior-Level Black Men Administrators At Historically White Institutions
}

DuJuan Eugene Smith

Illinois State University, dujuansmith@gmail.com

Follow this and additional works at: https://ir.library.illinoisstate.edu/etd

Part of the Higher Education Administration Commons

\section{Recommended Citation}

Smith, DuJuan Eugene, "Black While Leading: Unmasking The Anti-Black Lived Experiences Of SeniorLevel Black Men Administrators At Historically White Institutions" (2020). Theses and Dissertations. 1324.

https://ir.library.illinoisstate.edu/etd/1324

This Dissertation is brought to you for free and open access by ISU ReD: Research and eData. It has been accepted for inclusion in Theses and Dissertations by an authorized administrator of ISU ReD: Research and eData. For more information, please contact ISUReD@ilstu.edu. 


\section{BLACK WHILE LEADING: UNMASKING THE ANTI-BLACK LIVED EXPERIENCES OF SENIOR-LEVEL BLACK MEN ADMINISTRATORS AT HISTORICALLY WHITE INSTITUTIONS}

\section{DUJUAN EUGENE SMITH}

178 Pages

This study explored the anti-black lived experiences of 9 senior-level Black men who are administrators at Historically White Institutions. Black critical theory (BlackCrit) and theory of marginality and mattering are the guiding frameworks used to examine the lived experiences of the Black administrators. The purpose of this study was to reveal the ways that Black seniorlevel administrators process, navigate, and make meaning of their lived experiences and antiblackness at HWIs. Critical ethnography was used as the research methodology to help reveal the personal reflections and strategies that Black men who are senior-level administrators engage in to combat the pervasiveness of anti-blackness. From the in-depth interviews and field observations with the participants, two themes emerged: anti-blackness and Blackness. These themes suggested that Blackness is the cure for anti-blackness. The anti-black lived experiences identified in this study revealed that these were the sub-themes for reflections: sundown institutions, personal sacrifices, and work twice as hard. Blackness was recognized as a form of resistance against anti-blackness through these sub-themes for strategies: Black and Proud, Wakanda, and hiding in plain sight. By embracing Black identity coupled with sharing their lived experiences, anti-blackness at HWIs can be exposed, disrupted, and reimagined by Black men who are senior-level administrators.

KEYWORDS: anti-blackness, Blackness, Black critical theory, Black administrators, Black men 
administrators, critical afropessimism, historically white institutions, marginality and mattering, sundown institutions, Wakanda 
BLACK WHILE LEADING: UNMASKING THE ANTI-BLACK LIVED EXPERIENCES OF

SENIOR-LEVEL BLACK MEN ADMINISTRATORS AT HISTORICALLY WHITE INSTITUTIONS

DUJUAN EUGENE SMITH

A Dissertation Submitted in Partial

Fulfillment of the Requirements

for the Degree of

DOCTOR OF PHILOSOPHY

Department of Educational Administration and Foundations

ILLINOIS STATE UNIVERSITY

2020 
(C2020 DuJuan Eugene Smith 
BLACK WHILE LEADING: UNMASKING THE ANTI-BLACK LIVED EXPERIENCES OF SENIOR-LEVEL BLACK MEN ADMINISTRATORS AT HISTORICALLY WHITE INSTITUTIONS

DUJUAN EUGENE SMITH

COMMITTEE MEMBERS:

Pamela Twyman Hoff, Chair

Lydia Kyei-Blankson

Lenford Sutton 


\section{ACKNOWLEDGMENTS}

"There is no greater agony than the untold story inside you." -Maya Angelou

First and foremost, I give honor to God who is the head of my life and the source of light. Thank you for blessing me with my guides who give me strength and direction as I serve your purpose. To my mother, Brenda Banks, who has been my everything. Thank you for always believing in me and supporting my dreams even when you did not understand them. I appreciate all that you have sacrificed for us to have more choices in life. To my father Arlo, thank you and I am glad we have embraced building a connection. To my stepfather Gregory, thank you for being one of the first to recognize and celebrate the inner scholar in me. I was not ready then to embrace it, but now I am in it and it is in me. To my brother Dion, thank you for simply being you. You inspire me. You challenge me. You push me. I am grateful for the person you are and the person God is transforming you to become. To my sisters Latrice and Latesia, I appreciate your unwavering love and support. It is amazing to see the dynamic women you have grown into. Sending nothing but love and honor to the rest of my family--Smiths, Millers, Denards, and Perrys--for continuously believing in my natural abilities.

Your friends are the family you choose for yourself. I have been blessed with an unbelievable Wakanda: some of the most dope spiritual beings in human form who have made my life worth living. Thank you to the following people: Shaun and Dr. Kelly Crisler, Jarvis and Tiondra Purnell, Dr. Alexis Westbrook, Alexis Butler, Joy Hutton, Marjorie Wallace, Kenneth Stratton, Yuije Sansone, Joseph Williams, Alandis Phillips, Michael Johns, Fuad Larry Raji, Alex Thervil, Kevin “KG” Gordon, Derrick Martin, Harold Toliver, Jaemin Robinson, Ariel Hamilton, Brandon Lee Hunter, Joseph and Yinka Boudreaux, Annette Wright, Colette Tobias, Kameron Brackins, Dr. Terence Turner, Jarquetta Egeston, Marcus Dailey, Antar Khan, George 
Rice, Willie Payton, Melissa Abrams, Dr. Alison Wells, and to the Brothers of Alpha Phi Alpha Fraternity Incorporated (S/O to my home chapter--the ARROGANT Epsilon Phi). I am also thankful for my therapist, Quincey Kyles, and my energy healer, Elizabeth McCartney.

Many mentors, colleagues, and professional spaces have come into my Wakanda and encouraged me to shine my light on the world. I give honor to the following: Dr. Todd Yeary, Dr. Leon Caldwell, Dr. Brian Hemphill, Derrick Smith, Dr. Kimberly (KJ) Jones, Dr. Lee Covington Rush, Chad and Carol Simmons, Juan Gardner, Dr. James Mendez, Dr. Lori White and Anthony Tillman, Carmita and George Semaan, Dr. Stacy Rothberg, Mari Strombom, my Semester-at-Sea Spring 2014 and Spring 2020 Family, \#BlackatSea, \#NiteCrew (DeWun Owusu \& Valissa Thomas), my Surge Family (S/O to the Insurgents), ASCA, Bro. John Jordan (deceased), and Dr. Chet Shaw.

To my dissertation committee, Dr. Lenford Sutton and Dr. Lydia Kyei-Blankson, thank you for your input, guidance, and belief in this study. You have poured into me and have helped to shape the scholar I am today. Dr. Sutton, thank you for affirming the necessity of this research through our conference presentation. The investment you have made will not only yield significant returns of immeasurable prosperity but will be paid forward and reinvested in future scholars and Black administrators. To the "fourth" member of my dissertation committee, the late Dr. Joseph White, the Godfather of Black Psychology; You were one of the strongest proponents of me pursuing this Ph.D. I never got to tell you how much you meant in my life and I never got to tell you I was accepted into the program. I always envisioned that you would be on my committee, so I made you the symbolic fourth member. You taught me that "research is a form of liberation for our people whose stories need to be told." This dissertation accomplishes that and more. I have kept the faith and I pray you are proud. 
To my dissertation chair, mentor, friend, and fellow scholar, Dr. Pamela Twyman Hoff, affectionately known as Queen Scholar, you have taught me to be true to myself and to speak truth to power without compromise. You are regal, extraordinary, and unapologetically \#BlackAF. Every moment in your midst is a gift as you drop precious gems loaded with elements of liberation. Your love and investment in building community is simply inspiring! You are living your ministry and making the ancestors (especially Dr. Peavy) proud at the same time. Thank you for your sacrifice and resilience--for always making yourself available to your community when needed. In your words, "I bet on Black every time!" Thank you for betting on this study from conceptualization to its manifestation. Now let's build this league of extraordinary scholars!

A huge shoutout goes to my Day 1, Dr. Jacqueline Hester. Thank you for your light, presence, and love. I am blessed that God intersected our paths. Having you through this process has been a gift and I look forward to the many adventures we have ahead, even with the Feds watching (inside joke). Thank you, Brian Hester, for your support of both Jackie and I through the whole doctoral program.

To the participants of this study, I appreciate you all for using your voices to disrupt and transform the lived experiences for future Black administrators at historically white institutions. I thank you for trusting me with your identities, stories, and perspectives. To my editor, Cynthia Banks, I honor and appreciate you. You refined this masterpiece and I could not have crossed the finishing line without you. Your assistance means more than you will ever know.

In an untraditional form of gratitude, I have to acknowledge the arts (i.e., music, movies, TV shows, etc.) that were a part of my journey and inspired many aspects of this dissertation. The following creations were sources of creation and creativity: HBO's Lovecraft Country; 
Hennessy (\#1765); Mos Def--Umi Says; All things created by Big Sean; Solange--God Given Name; Ms. Lauryn Hill--I Find it Hard to Say (Rebel); Jay Z--Moments of Clarity (9th Wonder Remix); Inward by Yung Pueblo; Tamela Mann--Take Me to the King; Yolanda Adams--In the Midst of It All; Peace from Broken Pieces by Iyanla Vanzant; Ava DuVernay's When They See Us (Netflix); Kanye West featuring Nas--We Major; Nicki Minaj--Yikes; SAINt JHN--God Bless the Ratchets; Lupe Fiasco--I'm Beamin'; and Kehlani--Piece of Mind;

In closing, I am overwhelmed with gratitude for all of the people in my tribe who showed up for me during this process. In the heart of two pandemics--COVID-19 and anti-blackness-this was not an easy process. I did not just pick a random topic to study; I chose to unpack the anti-blackness I had experienced in higher education. This is my life, and like my participants, my whole life is a protest. And now, this whole dissertation is a protest: a radical expression of resistance and a love letter to the greatest part of me--my Blackness. I am so thankful to myself for choosing the doctoral journey, submerging myself into the totality of this experience, and for being unafraid of "burning down the bridge while standing on it."

I dedicate this dissertation to my late grandmother, Carlean Smith, who made this all possible. YOU went home to be with the Lord in April 2020, and you are missed dearly. I wish you were here to see this moment, but I respect that God had other plans. I promise to proudly live life to the fullest, in your loving memory, as one of the cherished heirs of your legacy. I also dedicate this dissertation for my God children, Jaylah, Zayah, and Jayce Purnell; this is for you all!

D. E. S. 


\section{CONTENTS}

Page

ACKNOWLEGMENTS

TABLES

CHAPTER I: INTRODUCTION 1

First Black Man Administrator at an Historically White Institution (HWI) 2

$\begin{array}{ll}\text { Positionality } & 4\end{array}$

Blackness Undenied 4

$\begin{array}{ll}\text { Higher Education } & 6\end{array}$

My Lived Experiences as an Administrator $\quad 7$

Statement of the Problem 11

$\begin{array}{ll}\text { Purpose of the Study } & 14\end{array}$

$\begin{array}{ll}\text { Research Questions } & 15\end{array}$

$\begin{array}{ll}\text { Guiding Frameworks } & 15\end{array}$

Significance of the Study $\quad 16$

$\begin{array}{ll}\text { Important Terms } & 17\end{array}$

$\begin{array}{ll}\text { Summary } & 20\end{array}$

CHAPTER II: ANTI-BLACKNESS 21

The Tie That Binds: Anti-blackness and Racism 23

$\begin{array}{ll}\text { The Black Body } & 25\end{array}$

$\begin{array}{ll}\text { Fear of the Black Man } & 26\end{array}$

$\begin{array}{ll}\text { Space Traders } & 30\end{array}$

Anti-blackness in Higher Education 32 
Blackness

Summary

CHAPTER III: LITERATURE REVIEW 40

$\begin{array}{ll}\text { Frameworks } & 40\end{array}$

$\begin{array}{lr}\text { BlackCrit } & 40\end{array}$

Theory of Marginality and Mattering 44

Problems Faced By Black Administrators $\quad 46$

Bamboozled: Access to Power Without Being Empowered 49

Good for You, Not for Me $\quad 50$

Recruitment and Retention of Black Administrators

Defining Administrators $\quad 52$

$\begin{array}{ll}\text { Recruitment } & 54\end{array}$

$\begin{array}{ll}\text { Retention } & 55\end{array}$

$\begin{array}{ll}\text { Tokenism } & 56\end{array}$

$\begin{array}{ll}\text { Pawn } & 58\end{array}$

$\begin{array}{ll}\text { Between Two Worlds } & 60\end{array}$

The Underrepresentation of Black Administrators $\quad 64$

$\begin{array}{ll}\text { Summary } & 67\end{array}$

$\begin{array}{ll}\text { CHAPTER IV: METHODOLOGY } & 68\end{array}$

$\begin{array}{ll}\text { Research Questions } & 68\end{array}$

Rationale for Qualitative Research Design $\quad 68$

$\begin{array}{ll}\text { Critical Ethnography } & 70\end{array}$

$\begin{array}{ll}\text { Participants and Recruitment } & 72\end{array}$ 
$\begin{array}{ll}\text { Data Collection } & 73\end{array}$

$\begin{array}{ll}\text { Data Analysis } & 75\end{array}$

$\begin{array}{ll}\text { Trustworthiness } & 77\end{array}$

$\begin{array}{ll}\text { Potential Risks } & 79\end{array}$

Ethical Issues and Reciprocity $\quad 80$

$\begin{array}{ll}\text { Summary } & 81\end{array}$

CHAPTER V: RESULTS

A Village of Nine Senior-Level Black Men: The Participants 83

$\begin{array}{ll}\text { Trayvon } & 84\end{array}$

$\begin{array}{ll}\text { Fred } & 85\end{array}$

$\begin{array}{lr}\text { Eric } & 85\end{array}$

$\begin{array}{ll}\text { George } & 86\end{array}$

$\begin{array}{ll}\text { Medgar } & 87\end{array}$

$\begin{array}{lr}\text { Malik } & 87\end{array}$

$\begin{array}{lr}\text { Michael } & 88\end{array}$

$\begin{array}{ll}\text { Ahmaud } & 90\end{array}$

$\begin{array}{lr}\text { Martin } & 90\end{array}$

Theme 1: Anti-blackness $\quad 91$

Sundown Institutions $\quad 91$

$\begin{array}{ll}\text { Personal Sacrifices } & 100\end{array}$

$\begin{array}{ll}\text { Work Twice as Hard } & 106\end{array}$

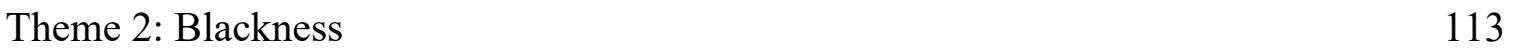

$\begin{array}{ll}\text { Black and Proud } & 113\end{array}$ 
$\begin{array}{ll}\text { Wakanda } & 115\end{array}$

Hiding in Plain Sight 118

$\begin{array}{ll}\text { Summary } & 123\end{array}$

$\begin{array}{ll}\text { CHAPTER VI: DISCUSSION AND IMPLICATIONS } & 124\end{array}$

$\begin{array}{ll}\text { Interpretation of Findings } & 124\end{array}$

$\begin{array}{ll}\text { Themes } & 125\end{array}$

$\begin{array}{ll}\text { Anti-blackness } & 125\end{array}$

$\begin{array}{ll}\text { Sundown Institutions } & 125\end{array}$

$\begin{array}{lr}\text { Personal Sacrifices } & 126\end{array}$

$\begin{array}{ll}\text { Work Twice as Hard } & 127\end{array}$

$\begin{array}{ll}\text { Blackness } & 127\end{array}$

$\begin{array}{ll}\text { Black and Proud } & 127\end{array}$

$\begin{array}{ll}\text { Wakanda } & 128\end{array}$

$\begin{array}{ll}\text { Hiding in Plain Sight } & 128\end{array}$

$\begin{array}{ll}\text { Implications for Theory and Practice } & 129\end{array}$

$\begin{array}{ll}\text { BlackCrit } & 130\end{array}$

Theory of Marginality and Mattering 131

$\begin{array}{ll}\text { Limitations } & 131\end{array}$

Implications for Future Research 132

$\begin{array}{ll}\text { Recommendations for Practice } & 134\end{array}$

Institutional Recommendations 134

Recommendations for Black Administrators 135

Extracted Recommendations From Participants 136 
Trayvon 136

$\begin{array}{ll}\text { Fred } & 136\end{array}$

$\begin{array}{ll}\text { Eric } & 137\end{array}$

$\begin{array}{ll}\text { George } & 137\end{array}$

$\begin{array}{ll}\text { Medgar } & 138\end{array}$

$\begin{array}{ll}\text { Malik } & 138\end{array}$

$\begin{array}{ll}\text { Michael } & 138\end{array}$

$\begin{array}{ll}\text { Ahmaud } & 139\end{array}$

$\begin{array}{ll}\text { Martin } & 139\end{array}$

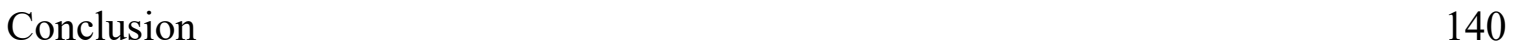

REFERENCES 142

APPENDIX A: EMAIL LETTER FOR PARTICIPANT NOMINATION 161

APPENDIX B: EMAIL LETTER TO PROSPECTIVE PARTICIPANT 163

APPENDIX C: PARTICIPANT CONSENT FORM 165

APPENDIX D: REFERRED COLLEAGUE PARTICIPANT CONSENT 168

APPENDIX E: INTERVIEW QUESTIONS 171

$\begin{array}{ll}\text { APPENDIX F: PREINTERVIEW ARTICLE } & 174\end{array}$ 


\section{TABLES}

Table $\quad$ Page

1. Participants' Demographic Information 73 


\section{CHAPTER I: INTRODUCTION}

"Do I really want to be integrated into a burning house?"

(Baldwin, 1993, p. 94)

On November 4, 2008, Senator Barack Obama was elected the 44th President of the United States making him the first Black person to ascend into the highest office of the land. This was a historic moment to witness as a Black family moved into the White House, which was built by both freed and enslaved Black people in 1792 (White House Historical Association, n.d.). Many did not believe they would ever see the day where a Black person would lead this nation. The origin of this skepticism is best articulated by Glaude (2016) when he said, For much of our national history we have struggled mightily with the issue of race. The evil of slavery shadowed the birth of this country. Previous ideas like 'all men are created equal' were congenitally deformed by the idea that some men and women are valued less than others because of the color of their skin. (p. 9)

Many Americans chose to believe the Presidency of Barack Obama represented the arrival of a post-racial society; however, there were people who knew that a country with a 400 -year complex relationship with race, white superiority, and inequity would not be able to shed this reality overnight. Furthermore, the symbolism of President Obama's ascension into the White House could never change the United States' historical DNA of violence against Black people. In Coates' (2012, para. 16) article, "Fear of a Black President," he quoted Cornell Belcher, a pollster for Obama who said, “The thing is, a black man can't be president in America, given the racial aversion and history that's still out there; however, an extraordinary, gifted, and talented young man who happens to be black can be president." Coates surmised this statement as a perfect reflection of Obama's era and an illustration of the power of racism. Sadly, this sentiment 
sets the stage for my intellectual curiosity of high-level Black leaders in historically white spaces.

Prior to President Obama's election, 43 white men occupied the position that was originally intended for white men. This by whites, for whites phenomenon is true of almost every industry and institution in America. Just as President Obama became the leader at the highest level in American government, almost every industry has experienced Black first in the wake of anti-discrimination legislation such as Title VII of the Civil Rights Act of 1964 and the Supreme Court desegregation ruling of Brown v. Board of Education (1954). Black people have gained access in these industries; however, we are still vastly underrepresented across the spectrum-higher education being no exception.

\section{First Black Man Administrator at an Historically White Institution (HWI)}

Long before Barack Obama would become the 44th President of the United States, Patrick Healy became the first Black, senior-level administrator at an historically white institution (HWI). In 1873, he became the first Black man to become president of the HWI, Georgetown University, after the sudden death of the sitting president (Mendoza, 2004). Prior to becoming president, he served as the first Black Academic Dean. Today, Patrick is celebrated by Georgetown University as an outward expression of their early and current dedication to diversity; however, what is absent from this rhetorical discourse is that Healy not only passed for white, but he lived in fear of people discovering that he was Black.

Outwardly, Patrick Healy lived and appeared to be a white man. As the son of an Irish Catholic and a biracial domestic slave, the politics of the "one-drop rule" made him Black despite the fact that his light skin and fair complexion made others perceive him as white (Mendoza, 2004). Growing up, Healy thought he could not escape the threat of people knowing 
of his family's Black heritage. O'Toole (2002) noted, "He needed an enforced forgetting of who he was, and he advanced that process by going away to live among those who were not 'wellacquainted' with him or his family" (p. 153). He decided to pursue Jesuit priesthood in Europe.

His ordination into Jesuit priesthood in 1864 eliminated the possibility of marriage and children for Healy. Most significantly, this act solidified that no one would know of his true Black identity for which he was actively committed to concealing (Mendoza, 2004). He returned to the states to aid Georgetown University in its critical formative years. He was immediately well received and extremely likeable.

Interestingly enough, Healy intentionally stayed away from Black people at Georgetown University who worked in service (i.e., cooking, cleaning, etc.). He knew that if anyone found out about his Black identity, it would mean the end of his initiatives, relationships, and legacy. Although he remained close to his two brothers who looked Black, he reunited with them at various points of his life in secret.

Healy worked hard to build a legacy at Georgetown. His presence and contributions to the institution are the reasons many people considered him to be the second founder. But the hardest part of being Patrick Healy might have been in the suppression of his Black identity. One might wonder about the mental, physical, and emotional toll he endured by harboring his Black identity. How often in his daily lived experiences did fleeting moments of fear debilitate his actions and movements? Did this secret keep him up at night or did he bury it so deep in the bows of his subconscious that he never missed a minute of sleep? One may never know the answer to these questions; however, Healy's situation seems to foreshadow the state of today's Black administrators at HWIs. 


\section{Positionality}

Somewhere along the way I lost myself. I cannot even pinpoint when it happened, but it did. Like Healy, I was slowly trimming my Black identity, beliefs, and most importantly my voice to fit into spaces that were never designed for me to fit. My doctoral journey forced me to face an unthinkable reality about my life as a Black administrator in higher education--I had become a public success and a private mess. It was not easy to come to grips with this reality because for all intended purposes, I appear to be a success in the field. I am deeply involved in various professional organizations, acquired many awards for my service, and often sought after to be a mentor for graduate students and newly hired professionals. Although I have found a passion for my work and recognize that I am undeniably good at what I do, I wrestle with the question, “Just because I am good for it, does it mean it is good for me?" Furthermore, I was terrified at the thought of achieving success as a senior-level administrator at the expense of the most salient part of my identity--my Blackness.

\section{Blackness Undenied}

Unlike Healy, I could not suppress and deny my Blackness. I always knew I was Black. More specifically, I cannot think of a time in my life where I did not know my Blackness made me different for some reason. Growing up on the southside of Chicago, I lived in a predominantly Black neighborhood. I ventured outside of my community with friends and I was often overwhelmed by the stark differences in different parts of the city. Chicago is a very segregated city. The geographical locations within the city are divided by race and class. My interactions with white people only occurred during my adventures navigating downtown. My mother always stressed the importance of never being in those neighborhoods when the sun went down because "bad things happen to us in those places at night." My entire world was Black, but 
it was not until I went to college that I discovered the diversity in Blackness.

Though my mother never went to college, she made it very clear that "either you are going to college or you are getting out of my house." I formed an affinity for the college experience through Bill Cosby's sitcom, A Different World and was determined to find “my Hillman.” Historically black college and universities (HBCUs) were the only choices selected during my senior year of high school. I attended Tennessee State University (TSU) for my first year and quickly learned that Black people are different. I thought all of us were from the "hood" and struggled with finances. At TSU, I met Black people from all over the world: Black people with very different views and perspectives. My eyes were opened to the beauty in many hues of being Black.

I transferred to Northern Illinois University (NIU), and decidedly, it was a transformative experience. Through my minor in Black Studies, I was exposed to Black faculty in the Center for Black Studies, a place that became my home away from home. In my African Philosophy class, my professor, Dr. Todd Yeary, shared his experiences in Ghana through storytelling. I cannot remember exactly what he said, but I [know I was compelled to act: I went directly to the study abroad office and signed up. On May 19, 2001, I discovered Ghana and Ghana found me!

The most significant moment in Ghana was when we visited the slave dungeons. Many people refer to them as castles, but royalty never lived there so I cannot use a glorified name for oppression. The night beforehand, I went to sleep at 5 p.m. after we were done with classes and I did not wake up until 7 a.m. the next morning. When we pulled up to the dungeon of Cape Coast, we formed a circle and grabbed hands. Our professors performed a ritual to prepare our mind, bodies, and spirits for what we were about to experience. I heard them chanting and as they went to each one of us and touched our heart, I was calm. When we walked in, the first thing I saw 
was the church in the middle of the dungeon; I was enraged because you could still smell human flesh in each of the cave quarters. When I entered the men's quarters of the dungeon, something familiar came over me. I cannot explain it, but I knew my way around that dungeon. I was drawn to one particular spot. When I stood in that spot, I was overcome with so many emotions: angry, sadness, fear, and hopelessness. At the end of each dungeon visit, we prayed at the Door of No Return and it was in that moment that I was reborn. I could feel the fire burning inside of me and I knew that I had work to do when I returned to the United States. I came back to NIU and became the premiere student leader because I was connected to a cause and purpose beyond my own existence.

\section{Higher Education}

I returned NIU with a strong connection to my Black identity and passionate about transforming the lives of others. Through student leadership, I was introduced to a higher education administrator in the division of Student Affairs--a senior-level administrator-a Black man. The nature of my involvement and his role caused our paths to intersect and he eventually became my mentor. Through our mentoring relationship, he shared his positive experiences as a Black administrator. What he did not share at the time were the negative experiences he encountered in his role. Nevertheless, he often affirmed my leadership qualities as a future asset to the profession. His presence as a Black administrator at NIU changed the trajectory of my career path. Seeing him established a vision of what could be for me; he was the first Black administrator with whom I made a meaningful connection. The intersection of his role as an administrator and his Black identity was the foundation for our mentoring relationship. It is scary to think that had he embraced Healy's ideology of Black identity suppression, we might have never connected. 
He referred me to the NASPA (National Association of Student Personnel Administrators) Undergraduate Fellows Program (NUFP), and I established another mentoring relationship with a mid-level white administrator working within his division. NUFP was created as a pipeline solution for undergraduate students of color to learn about Student Affairs as a career option. Through the NUFP program, I participated in a summer internship at Texas A\&M University and attended the NASPA Dungy Leadership Institute that same summer. Those experiences solidified higher education as a profession of choice for me.

\section{My Lived Experiences as an Administrator}

As I navigated being a Black administrator, I encountered many experiences that left me feeling unsafe as a Black man at a HWI. Patrick Healy avoided these experiences by cloaking his Blackness; however, this was not an option for me. When I was a new professional working my first job in higher education, I remember noting that every time I came to work wearing all-black attire, I would receive strange feedback. Throughout the day, people kept saying things that suggested the color black made me appear mean and intimidating. In passing, others would ask if I was staying out of trouble. What did that even mean--staying out of trouble? This statement was a little ironic because my role on campus was to address anyone who found themselves in trouble or who violated the institution's behavioral policies. I attempted to ignore these assertions; however, things reached a climax when I was asked to come into a closed-door meeting with a white mid-level administrator. The purpose of the meeting was to discuss my transition into the institution as a new professional. To my surprise, one of the topics that came up was my black attire. Even though I was assured I was not in any trouble, it was suggested that I consider wearing lighter colors like blue, pink, or purple to appear more welcoming to all students, faculty, and staff. I felt enraged and disappointed by what was happening, but when I 
was asked if I had any questions or concerns, I smiled and thanked her for the perspective.

I returned to the office and I decided to speak with my supervisor because he was a Black administrator at the institution. As I told him about the conversation, he acknowledged the inappropriateness of those comments, but he proceeded to remind me of the negative ways that my $6 \mathrm{ft} 2$ and $300 \mathrm{lb}$ stature can be perceived. At the end of our conversation, he recommended places for me to shop for professional attire in lighter colors--we had to play the game. His conversation left me feeling even more frustrated and devalued, but he was right. From that moment, I eliminated all black attire from my professional wardrobe and have never worn it again at work. The aftermath of this occurrence left me self-conscious of how people perceived me in the workplace. I lost a part of me that day--as a Black person, as a man, as an administrator. Unfortunately, this would only be the first of many times I walked away feeling this way.

Working as an administrator in student conduct, I was responsible for rendering decisions that can result in the temporary or permanent removal of a student from the institution. These decisions are not made lightly and typically, my area follows the process prescribed in the Student Code of Conduct, a document where University expectations for students are outlined. Given the nature of my work, I knew that anything I communicated in writing or verbally is subject to future litigation. In the 10 years that I have been in the field, I have been sued with the University twice. In every instance, University Counsel hired an external investigator to review my work and all documentation (i.e., letters, emails, notes) related to the case. The message was clear; as long as I did not do anything wrong, the University had my back. Three years ago, after consulting with a white senior-level administrator at another institution, I was advised to secure a professional liability insurance policy for the rest of my career. Her explanation was if the 
University made the decision not to support me, I would be responsible for all attorney fees, court cost, and any financial obligations or settlements ruled against me. Since that day, I have kept an annual professional liability insurance policy for my own protection.

A discrimination investigation was filed against me by a student. I interfaced with this student while fulfilling the obligations of my job. The student was unhappy with a decision made regarding his behaviors in a student conduct proceeding. In those hearing spaces, I serve as the facilitator for the five-party panel comprised of university faculty, staff, and student members. I am a non-voting member of the panel; however, my name is affixed to the outcome letter because of my role at the university. The student went through my Twitter post and discovered a picture I took of Minister Louis Farrakhan at the Frankie Beverly and Maze concert in Chicago 4 years prior. This photo was submitted as a claim of discrimination against the student because of my personal connection to Minister Farrakhan. It was alleged that my anti-Semitic views created a hostile school environment for the student. Keep in mind, I have no personal or religious affiliation with Minister Farrakhan; I simply took a picture of him.

The discrimination investigation lasted for over 3 months and I was not to have any contact with the student. Eventually, I was informed that the complaint had no merit, but it still warranted an investigation. The university administrator who investigated suggested that I consider deleting my Twitter picture of Minister Farrakhan so other students would not "get the wrong idea." Furthermore, I was advised to make my Twitter account private. I thanked the administrator for the recommendation, and I explained that I was not going to restrict my public Twitter account or delete any of my personal pictures because of the anti-blackness around me. I was being policed and harassed as a Black man--as a Black administrator--for doing my job.

The culmination of these experiences (i.e., discrimination investigation and follow-up 
recommendations) felt like death by 1,000 tiny cuts; the experiences were gradually picking me to pieces (Hoff, 2020) and had me wondering if I truly wanted to be a senior-level administrator in this profession. As I continued to achieve success in the field, Ghana and its impact on me began to feel further and further away. I was always present in my Black identity; however, I started to make small compromises to fit comfortably in the spaces I occupied. The impact of these negative experiences weighted heavy on me. I began to put my career over my own holistic well-being. I ascribed to the mantra work twice as hard to get half the credit and it was literally and figuratively killing me. I sought wise council and perspective from other Black administrators through sessions at conferences, but those spaces never seemed to go beyond the surface. I felt isolated: isolated in the way I believed Patrick Healy might have felt at times as he navigated HWIs without his Blackness. In many ways, he intentionally avoided these harsh experiences by suppressing his Black identity. Not only was I unwilling to deny my Blackness, I could not do that even if I wanted to because my skin complexion reveals my Blackness. It is what people see before they hear me.

As people kept telling me how much of a great senior-level administrator I would be, I felt the tension in my chest every time I thought about the possibility. There was never a doubt that I possessed the skills and personality to accomplish this goal. What I was troubled by was how much more of myself was I going to lose to progress in this field. I made a proactive decision to pursue a Ph.D. program in higher education administration in the event I did want to explore the possibility of senior-level administration in the future. As I navigated through the coursework, my feelings continued to show up in my papers, class discussions, and reflections. There was something happening to Black administrators at HWIs, but I did not know what to call it. When I read about Patrick Healy suppressing his Black identity, I had an epiphany. It became 
abundantly clear that this dissertation had to explore the anti-black lived experiences of seniorlevel administrators at HWIs. This was an important topic for me but also necessary to create a space where other Black men desiring to become senior-level administrators could critically examine the feasibility of this career path without pretense or illusions.

\section{Statement of the Problem}

Black men are suffering (Lee \& Hicken, 2016; Smiley \& Fakunle, 2016; W. Smith, Hung, \& Franklin, 2011; Stripling, 2019) as administrators at HWIs because these institutions are built on a graveyard of violence against Black people; thereby making it a site of suffering (M. Dumas, 2014). Access never guaranteed equality or equity. Black men in administration are paying unspoken costs to ascend to the highest positions in these historically white dominated spaces. Not only are they not immune from the toxicity of these environments, but they have become numb to the daily exposure of these deadly levels of anti-blackness in the ether. Possessed by these spirits of iniquity, they are forced to mask their experiences to survive in complex places (Brooks \& Arnold, 2013; Dancy, Edwards, \& Earl Davis, 2018; Hicks \& Watson, 2018; W. Smith et al., 2011). Despite these circumstances, I believe there is something that grounds them in spite of their reality.

As a trained therapist, one of the first things taught is to identify the problem, which is often revealed through the symptoms described: then determine the appropriate solutions designed to remedy the problem. This practice is not specific to the world of therapy: When one visits a medical doctor, the first question posed is to determine the problem - the reason for the visit. Doctors proceed by asking patients to describe what they are experiencing. Based on the response, the doctor begins to determine a possible diagnosis that aligns with the symptoms. In the end, the goal is to pinpoint the problem to create a solution that would eliminate the problem 
or greatly reduce the symptoms being experienced. An important piece that must be understood in this process is the diagnosis (the problem) that will be used to develop the treatment plan (the solution), which is only as good as the information provided (the symptoms). I believe that there is a misalignment in the triad of symptoms, diagnosis, and treatment plan because Black men administrators are not acknowledging or naming anti-blackness as a critical contributing factor of their experiences.

"Microaggressions, tokenism, impostership, and racial battle fatigue attest to the psychologically torment regularly visited upon Black humanity in higher education" (Dancy et al., 2018, p. 188). Furthermore, navigating racial oppression and marginalization is not only a consistent part of the daily routine; it is the equivalent of breathing (Riley, 2020). "The term university administrator refers to an individual in a managerial or policy-making capacity that may have a line or staff function" (Wolfe, 2013, p. 25). Senior-level administrators represent the highest positions at an institution; they are in charge of the oversight for management and operations. Unfortunately, the reality for most Black administrators is they will not end up in positions of power--leaving many of them left feeling marginalized and tokenized. "In most instances, Black administrators have been given responsibility, but they have not given power and authority in the formal administrative structure of the institution commensurate with that responsibility" (C. H. Smith, 1980, p. 324).

The majority (86\%) of higher education administrators are white. Black administrators represent $7 \%$ of higher education administration, which includes senior-level executives, department heads, and deans (Seltzer, 2017). The underrepresentation of minorities in higher education administrative positions mirrors that of private industry, where $87 \%$ of senior level executives are white (Bichsel \& McChesney, 2017). Out of the 256,267 university administrators 
reported in the Fall 2016, 114,027 were men and 145,240 were women. When broken down further, 196,323 represent the white men and women university administrators while 55,841 represent the Black men and women university administrators. Black men represent only 21,602 university administrators while Black women represent 34,239 (National Center for Education Statistics, 2017). My extensive search for specific statistics on senior-level administrators yielded no results. In addition, documented experiences involving senior-level Black administrators and anti-blackness is also lacking.

As I reviewed the limited literature on Black men administrators, one position that was never quite articulated but continued to resonate with me was this: No one should have to experience what I did just for being Black and wanting to advance to higher positions. Dugas (2002) offered this comment:

The wonder of Black people is that we are still advancing despite the untenable circumstances that we find ourselves in. The harsh reality is that its outcome is usually revealed in high stress, fatigue, burnout, and more intense stress-related illnesses. ( p. 85) Black people are resilient. Given the things they have had to endure in this country, one should never be surprised as they continue to break glass ceilings despite their experiences (Harvey, 1999). More important, how has their Black identity served as an asset as they navigated these white spaces.

In addition, a significant gap or missing narrative detailing how Black administrators make sense of their lived experiences exists. Limited articles and studies that focused on career trajectory were available, but I found it nearly impossible to find anything that collectively spoke to the Black identities of administrators in relation to the intersection of their gender and university position. However, I persisted in my quest to understand how Black men 
administrators survived and thrived in these HWI environments.

\section{Purpose of the Study}

The purpose of this qualitative research study was to unmask the ways that senior-level Black administrators process, navigate, and make meaning of their lived experiences and antiblackness at HWIs. This lived experience or "L'expérience vécues” as said by Frantz Fanon and quoted by Gordon (1997), explains what it is like to be Black (an objective fact) in the contemporary culture of HWIs (Browne, 2015). A salient reason for my interest in exploring the experiences of Black administrators lied within my own positionality as a Black administrator.

The truth is, the totality of my lived experiences as a Black man in an anti-black world significantly informed my positionality for this particular study. M. C. Woodard and Harris (1978) offered the following perspective:

The job of illuminating some of the unique sources of stress and strain of the Black administrator is one for Black scholars. It may be that any scholar can do it, but it would appear that the Black scholar would have special insight into doing the kind of job that is needed. Because he is the one who experiences the stress that we are discussing here, he is in the best position to describe and analyze it. (p.

I believe I was called to unmask the lived experiences of Black administrators. I am both an insider and an outsider. Banks (1998) described the indigenous insider as someone from a community and one who is seen by other people in that community as a person worthy of speaking on the experiences within. The indigenous outsider is someone who may have been socialized within a community but is seen as an outsider because he or she is perceived to have assimilated to another culture. As a Black mid-level administrator at an HWI, I am considered an 
insider; however, I am an outsider to the senior-level Black administrator experience. This study was designed to capture and expand the literature on senior-level Black administrators at HWIs.

\section{Research Questions}

This study was guided by the following research questions:

1. How do senior-level Black men who are administrators navigate anti-blackness at HWIs?

2. In an HWI context, what extent does anti-blackness affect Black men's ability to lead?

3. In what ways do Black men administrators use their Blackness to navigate HWIs?

4. How do Black men make sense of their administrative role and responsibilities in an HWI?

5. How do Black men administrators prepare for the opportunities and challenges of being a senior-level administrator at an HWI?

\section{Guiding Frameworks}

Dual guiding frameworks were used for this research: Black critical theory (BlackCrit) (Dumas \& Ross, 2016) and theory of marginality and mattering (Schlossberg, 1989). Together, these frameworks highlight the lived experiences of Black men who are administrators in higher education. These frameworks were essential as they complimented each other. Because of the ubiquity of anti-blackness, I anticipated that the participants of this study might be unable to recognize and verbalize their experiences using the language of anti-blackness. Marginality and mattering provided familiar language to conjure the breadth and scoop of their experiences, which created an opportunity for translation in the data analysis process. This study is a vital learning tool for HWI administrators to develop and provide resources for systems to recruit, support, and retain future Black administrators who aspire to obtain senior-level positions. 


\section{Significance of the Study}

Based on my own lived experiences and positionality, I made the decision to focus this study on Black men who are administrators. I yearned to take a deeper dive into the experiences of Black administrators to help make meaning of my own experiences. After conducting a search in various library databases (e.g., EBSCO, ERIC, etc.), I discovered very limited existing literature on the lived experiences of Black administratrors: more specifically, senior-level Black administrators. One study did explore the upper-level Black administrators in community colleges as racially conscious leaders (Kirkwood, 2018); however, this study was not specifically focused on HWI settings. Primarily, available studies focused on racism, persistence, and retention among Black administrators at HWIs (Rollins, 2017; Seawood, 2005; Wolfe, 2010); explored the resilience of senior Black administrators at HWIs (Lewis, 2007); and studied career trajectories of Black administrators (Scott, 2016; Stokes, 2011). These studies were critical in setting the foundation to better understand how senior-level Black administrators were contextualizing higher-level positions in relation to the skills needed to access and sustain the position.

Additional studies examined the perception of Black administrators regarding administrative leadership opportunities (Thompson, 2016) and the characteristics of Black senior student affairs officers (Hammonds, 2012). These studies concentrated on aspects of the daily experience of Black administrators but did not place an emphasis on how these Black administrators navigated and defined their daily routine. Only one previous study closely resembled this study through its exploration of the lived experiences of Black male administrators at HWI (Pickron, 1991); however, the methodological approach was phenomenological. This study was guided by the methodological approach of critical 
ethnography. Furthermore, this study's incorporation of field observations in addition to in-depth interviews makes it unique among previous studies on Black administrators.

This study was a pioneer in its exploration of the lived experiences of Black men administrators in white spaces through the lenses of BlackCrit and Marginality and Mattering. By using BlackCrit as one of my guiding lenses, it is important to note that I was not researching whether anti-blackness against Black administrators at HWIs exists, but rather how senior-level Black men who are administrators thrive in spite of its existence. Participants were invited to express their anti-black lived experiences through the intentional reflection of their own Black identities. Often, the experiences of Black men administrators are probed through the lens of racism or white supremacy. From these perspectives, there is a tendency to oversimplify the depth and complexity of the deeply rooted dynamics at play. More specifically, BlackCrit positioned this study to unmask anti-black experiences, traditionally cloaked in the veil of racism, to reimagine the way future senior-level Black administrators are holistically trained, prepared, and supported along the way. Finally, this study was an innovator in its use of Marginality and Mattering as a guiding framework for higher education professionals (Black administrators) instead of students. Given the continued dialogue in society on the subject of mattering (i.e., Black Lives Matters), this study contributes an important perspective in understanding the next step for liberation.

\section{Important Terms}

The following definitions of terms and concepts are used throughout the course of the study. Understanding their meaning will help to clarify their relevance to this study.

- Anti-blackness: "Ideological practices of denigration and inferiorization of the Black/African subject in order to seek advantage and justify unequal treatment" (Dei, 
2017, p. 67). Anti-blackness is a socially constructed concept designed to eliminate and suppress the totality of Blackness in the world. Furthermore, it is a racial and cultural hatred rooted in the notion of white superiority to the Black body. The intentional use of non-capitalization of this term is a form of a resistance in this dissertation seeking to take away the power of this lethal construct.

- Anti-black racism: Espouses a world without Blacks as a better place, which leaves Blacks in a constant state of "must" justify our presence and existence (Gordon, 1997). Furthermore, it is "a particular negative reading, reaction and concrete response/action to Blackness" (Dei, 2017, p. 67). The intentional use of non-capitalization of this term is a form of a resistance in this dissertation seeking to take away the power of this lethal construct.

- Black: Michael J. Dumas (2016) defined Black as "a self-determined name of a racialized social group that shares a specific set of histories, cultural processes, and imagined and performed kinships” (p. 12). African American will be used interchangeably with Black; however, African American will only appear when I am quoting the works of other people. Blackness is expansive; it is nothing and everything at the same time. The intentional capitalization of Black in this dissertation is a form of resistance against antiblackness. It honors all of the lived manifestations of Blackness while uplifting the humanity of the Black identity.

- Black administrator: The focus of this study was to understand the lived experiences of those Black men who are administrators. In an effort to avoid redundancy, Black administrator will be used to reflect Black men administrators.

- Historically white institutions (HWIs): The term HWI is typically interchangeable with 
the term "predominantly white institution" (PWI), which "emphasizes that the gross numbers or percentages of white students have less to do with constituting the majority population than with the historical and contemporary racialized infrastructure that is in place" (W. Smith, Mustaffa, Jones, Curry, \& Allen, 2016. p. 1190). Furthermore, "the term PWI eradicates the historical dehumanization of enslaved peoples as property who built and maintained the upkeep of these 'prestigious' and PWI and universities" (Johnson, 2019, p. 1). Please note that PWI will only appear when I am quoting the works of other people.

- Senior-level administrator: A top-level executive within university administration residing in one of the following positions: President/Chancellor, Vice President/Chancellor, Associate/Assistant Vice President/Chancellor, Provost, Associate/Assistant Provost, Dean, \& Department Chair. These administrative leaders are in academic affairs and/or student affairs.

- white: Throughout the course of this dissertation, I have chosen not to capitalize the word white. Dumas (2016) pointed out, "[white] is nothing but a social construct and does not describe a group or a sense of common experiences or kinship outside of the acts of colonization and terror" (p. 13). The spirit of this expression is meant to attack the construct of whiteness, rooted in anti-black ideology and superiority. It does not necessarily reflect people who identify as white as whiteness and white people do not have to be synonymous. The intentional use of non-capitalization of this term is a form of a resistance in this dissertation seeking to take away the power of this toxic construct of whiteness. 


\section{Summary}

In this chapter, I contextualized this study by briefly discussing the experiences of Black administrators at HWIs. My positionality as the researcher for this study was outlined as well. The guiding research questions and frameworks were introduced. Even though previous research had been conducted about Black administrators at HWIs, the examination of the lived experiences of Black administrators at HWIs in relation to anti-blackness was missing. This study contributed and expanded the body of existing literature. Chapter II defined and unpacked anti-blackness. 


\section{CHAPTER II: ANTI-BLACKNESS}

"Racism [anti-blackness] in America is like dust in the air. It seems invisible--even if you're choking on it--until you let the sun in. Then you see it's everywhere. As long as we keep shining that light, we have a chance of cleaning it wherever it lands. But we have to stay vigilant, because it's always still in the air" (Abdul-Jabbar, 2020)

To fully understand the anti-black experiences of Black administrators at HWIs, we have to be clear about the ways Black people, specifically Black men, are seen in the context of the larger world and American society. It requires the interrogation of the Black body and how it has been commodified (e.g., property to be bought and sold), devalued, and stripped of its humanity (Ross, 2019). To contextualize this study, I narrowed my focus on the Black man's body. This chapter examines anti-blackness and its impact on higher education. As this significant concept is defined, it became equally important to hold space for Blackness as well. The question of Blackness was explored to understand the complexities in being Black in an anti-Black society and global community.

Words mean things and language matters. It is important to be clear about the language we hear and do not hear; language we use and do not use. Call it what it is--anti-blackness: Even though there appears to be an increasing social awareness of discrimination against Black people, there is an omnipresent denial of anti-blackness as foundational and structural fact (Vargas, 2018). Ross (2020) boldly declared anti-blackness as "a theoretical framework that illuminates society’s inability to recognize our humanity--the disdain, disregard, and disgust for our existence" (p. 1). Anti-blackness is a socially constructed concept designed to eliminate and suppress the totality of Blackness in the world by denying humanity to people of African descent (Parker, 2019). For the purpose of this study, I focused on the context of anti-blackness in America; however, it is important to name this is as a global phenomenon as many scholars have noted (Dei, 2017; Grant, Woodson, \& Dumas, 2019; Kendi, 2016; Vargas, 2018). Another way it 
can be defined is as "ideological practices of denigration and inferiorization of the Black/African subject in order to seek advantage and justify unequal treatment" (Dei, 2017, p. 67). It is a racial and cultural hatred rooted in the notion of white superiority to the Black body. None of us are safe from anti-blackness. In fact, its pervasive influence is embedded in its ubiquity, which means it is everywhere. I like to think of its presence as a shadow: that part of us that is always there, but rarely seen or acknowledged. Hunter (2016) described it as "penetrating and contaminating our conscious and unconscious thought patterns, directly and indirectly, as we breathe, grow, and reproduce" (p. 2). One of the biggest misconceptions about anti-blackness is that it can be vanquished or eliminated. Much of its power is gained in the ignorance of its existence. The purpose of this conversation is to shed light on the ways this thing called antiblackness is manifested.

Anti-blackness has emerged from the writings of scholars outlining afropessimism (Grant et al., 2019; Hart, 2018; Hartman, 1997; Patterson, 2018; Ross, 2019; Sexton, 2017; Wilderson, 2020). From the afropessimism perspective, in our world today, Blackness is permanently tied to slavery and can never be undone. This creates a perpetual pull between humanity and Blackness. Although Black people are not physically enslaved by white masters, slavery has an irresoluble stronghold on the state of being Black (Ross, 2019). Orlando Patterson (2018) introduced the notions of social death (the slave) and social life (the master) as a congruent paradigm that is reinforced through marginalization and systematic violence. What we are experiencing is what Saidiya Hartman calls the afterlife of slavery. Hartman (2007) offered the following explanation:

If slavery persists as an issue in the political life of Black America, it is not because of an antiquarian obsession with bygone days or the burden of a too-long memory, but because Black lives are still imperiled and devalued by racial 
calculus and a political arithmetic that were entrenched centuries ago. This is the afterlife of slavery--skewed life chances, limited access to health and education, premature death, incarceration, and impoverishment. (p. 6)

In other words, the conditions Black people are experiencing today occur because we are still haunted by the ghost of slavery and the plantation. Though the chains and shackles are physically gone, we are entangled by anti-black discrimination fueled by anti-black ideas that have been materialized into anti-black policies and laws.

\section{The Tie That Binds: Anti-blackness and Racism}

Racism is understood to incorporate two elements: "an ideology of superiority and the practice of inequity" (Peiterse \& Powell, 2016, p. 12). This understanding of racism is critical because it is this ideology of superiority and practice of inequity that sustains the permanence of its existence in our society; however, what is missing from this perspective is the acknowledgment of anti-blackness. Anti-blackness is the underpinning of the infrastructure of racism. It is a required prerequisite built into the fabric of racism. Racism cannot exist without anti-blackness even though anti-blackness can operate outside of the constructs of racism. Society makes limited progress on issues of race because it fails to address the anti-black thinking that provokes negative behaviors. Whiteness is rooted in this anti-black ideology of superiority that has materialized into theology (a firmly held belief) which has manifested into the perpetual practice of inequity against Black people (Peiterse \& Powell, 2016). This ideology was likely formalized and promoted following the implementation of the 1638 Maryland Doctrine of Exclusion. C. Anderson (1997) quoted the most ominous part of this public edict, "Neither the existing Black population, their descendants nor any other Blacks shall be permitted to enjoy the fruits of white society" (p. 43-44). This edict began to spread and was likely the 
impetus for slavery as well as subsequent actions taken against Black people to maintain white superiority. The spirit of this damning statement justified Black people being designated as property and not people. This anti-black ideology was infused into the most significant governing document that still dictates the laws and regulations of our country today--the United States Constitution.

The U.S. Constitution was signed in September of 1787 by the delegates at the Constitution Convention in Philadelphia, PA. Again, it is important to note the founders represented at the formation of this document were not Black. "In the preamble to their bold document, the founders cite prominently 'We the People,' but this phrase does not encompass the fifth of the population that is enslaved" (Feagin, 2001, p. 9). This fact illustrates the depths of how deeply rooted anti-blackness is in the construct of race.

According to Angle, Lincoln, and Douglas (1958), during the Lincoln-Douglas fourth debate on September 18, 1858, Abraham Lincoln made a similar declaration in the following statement:

I will say then that I am not, nor ever have been in favor of bringing about in any way the social and political equality of the white and black races, [applause]-that I am not nor ever have been in favor of making voters or jurors of negroes, nor qualifying them to hold office, nor to intermarry with white people; and I will say in addition to this that there is a physical difference between the white and black races which I believe will forever forbid the two races living together on terms of social and political equality. And inasmuch as they cannot live, while they do remain together there must be the position of superior and inferior, and I as much as any other man am in favor of having the superior position assigned to the white 
race. (p. 235)

The irony of Lincoln making these statements is that he eventually went on to sign the Emancipation Proclamation on January 1, 1863 that freed the slaves in the states outside of federal control without dealing with the issue of slavery within the bordering states. In the end, freeing the slaves was a calculated, political move and not one rooted in practicing equity while denouncing the ideology of superiority.

The term anti-black racism is more appropriate to use to acknowledge the dominance and pervasiveness of both of these dark matters. Anti-black racism espouses a world without Blacks as a better place, which leaves Blacks in a constant state of "must" justify our presence and existence (Gordon, 1997). The crux of the violence against Black people has mainly occurred through the physical, mental, emotional, and spiritual attack of the Black body.

\section{The Black Body}

The commodification of the Black body was used as a means to justify and gain a profit off the business of slavery. Slavery "is the permanent, violent domination of natally alienated and generally dishonored persons" (Patterson, 2018, p. 13). The trans-Atlantic slave trade sought to rob people of African descent of their customs, traditions, and physical manpower. This violence converted Black people from persons to things--inanimate objects. Ross (2020) said, "Black people were rendered as property, built this country, spilled literal blood, sweat, and tears into the soil from which we eat, the water we drink, and the air we breathe. The thingification of Black people is a fundamental component of the identity of this nation" (p. 3). The damage that has been done is deep, irreconcilable, and haunts Black people to this day (Kendi, 2016; Patterson, 2018; Ross, 2019; Wilderson, 2010). Hartman (1997) spoke the following sentiment: The relation between pleasure and the possession of the slave property, in both the 
literal and figurative senses, can be explained in part by the fungibility of the slave--that is, the joy made possible by virtue of the replaceability and interchangeability endemic to the commodity--and by the extensive capacities of property--that is, the augmentation of the master subject through his embodiment in external objects and persons. Put differently, the fungibility of the commodity makes the captive body an abstract and empty vessel vulnerable to the projection of others' feelings, ideas, and values; and, as property, the dispossessed body of the enslaved is the surrogate for the master's body since it guarantees his disembodied universality and acts as a sign of his power and dominion. (p. 21)

This perspective is vital to fully grasping the gravity of what thingifying Blackness has done. Fungibility makes the Black body necessary and disposable at the same time. The Black body as property created a paradigm coined by Achille Mbembe known as necropolitics, the politics of death. The technique of necropower "focused on the state's right to decide who may live and who must die as the "ultimate expression of sovereignty" (Robertson \& Travaglia, 2020, para. 5). Through policies and laws, institutions, particularly government entities, decided who lives or dies; what lives have value, and what lives do not have value (Mbembe \& Corcoran, 2019; MSNBC, 2020). Within the confines of the institution of slavery, Black bodies had a material value but not a human value. Black bodies were auctioned daily. Families were torn apart as individual members were sold and separated with the expectation of never seeing one another again. Laws were passed prohibiting slaves from reading, marrying, or traveling freely without the presence of a master or possession of freedom papers.

\section{Fear of the Black Man}

For over 400 years, fear was used as a strategy to force Black men in the United States 
into passive and cooperative submission to white men. From physical castration to lynching, unimaginable forms of violence and torture were inflicted on Black people during slavery (Welsing, 1991). Ore (2019) shared a perspective on the significance of lynching:

The lynching trope--particularly, the figure of the lynched Black body--is a profoundly violent symbol of white citizenship belonging that signifies, among other things, the ultimate price Blacks pay when they are believed to transgress the approved boundaries and precepts of their prescribed second status. (p. 102) The violent act of lynching and all other violent atrocities inflicted on the Black body were committed to instill fear and terror. Life of a slave resulted in "a triple loss: loss of a 'home', loss of rights over one's body, and loss of political status" (Mbembe \& Corcoran, 2019, p. 74). The Black body was used for the purposes of procreation, to increase revenue from the sale of Black children, and the sexual pleasure of anyone the slave owners allowed. The stereotype of the Black buck, also referred to as the Mandingo trope, was conjured by slave owners and auctioneers to promote the physical and sexual vitality of the Black man (The National Museum of African American History and Culture, 2019). The strength and breeding capabilities of Black men were a desirable selling point for prospective slave owners; however, those qualities had to be tempered with excessive violence against Black men to force them into labor. "If you make a man feel that he is inferior, you do not have to compel him to accept an inferior status, for he will seek it himself" (C. Woodson, 2011, p. 60).

Fear of the Black body existed before the founding of the United States and these strong ideas and beliefs have been circulated through newspaper, film, and popular culture (Glaude, 2016; Wilderson, 2010). The movie, The Birth of a Nation, portrayed Black men as dangerous and savage (Wilderson, 2010). Kendi (2016) outlined a brief historical snapshot of the pervasive 
fear of the Black body in the following passage:

Violence for white people really has too often had a Black face--and the consequences have landed on the Black body across the span of American history. In 1631, Captain John Smith warned the first English colonizers of New England that the Black body was as devilish as any people in the world. Boston pastor Cotton Mather preached compliance to slavery in 1696: Do not 'make yourself infinitely Blacker than you are already.' Virginia lieutenant-governor Hugh Drysdale spoke of 'the cruel disposition of those creatures' who planned a freedom revolt in 1723. Seceding Texas legislators in 1861 complained of not receiving more federal 'appropriations for protecting ... against ruthless savages.' U.S. Senator Benjamin Tillman told his colleagues in 1903, 'The poor African has become a fiend, a wild beast, seeking whom he may devour.' Two leading criminologists posited in 1967 that the 'large ... criminal display of the violence among minority groups as Negroes' stems from their 'subculture of violence.' (p. 70)

All of these examples illustrate how the installation of an overwhelming fear has fueled the degradation of the Black body. This white fear is "the general frame of mind that Black people are dangerous, not only to white individuals because they are prone to criminal behavior, but to the overall well-being of our society (Glaude, 2016, p. 74). This fear legitimizes a mindset that sees Black men as degraded, deficient, and as men who compensate through deviance and violence for their lack of manhood (Curry, 2017). This assiduous fear of Black men coupled with the social construction of these negative stereotypes have produced a criminalization of Blackness (Curry, 2017; Muhammad, 
2019; Sexton, 2017; Smiley \& Fakunle, 2016).

Trayvon Martin, Michael Brown, Eric Garner, George Floyd, and Ahmaud Arbery are the names of unarmed Black men killed by white police officers or white vigilante citizens emboldened to take matters into their own hands (Abdul-Jabbar, 2020; Curry, 2017; Serwer, 2020; Smiley \& Fakunle, 2016). Black Americans are nearly three times more likely than white Americans to be killed by police: five times more likely to be killed unarmed (Bor, Venkataramani, Williams, \& Tsai, 2018). Taylor (2016) described the struggle between the police and Black people in the following passage:

Police brutality has been a consistent badge of inferiority and second-class citizenship. When the police enforce the law inconsistently and become the agents of lawlessness and disorder, it serves as a tangible reminder of the incompleteness of formal equity. You cannot truly be free when the police are able to set upon you at will, for no particular reason at all. It is a constant reminder of the space between freedom and "unfreedom," where the contested citizenship of African Americans is held. (p. 108)

A study published by the American Psychological Association, Goff, Jackson, Di Leone, Culotta, and DiTomasso (2014) asserted that, "we find converging evidence that Black boys are seen as older and less innocent and that they prompt a less essential conception of childhood than do their White same-age peers" (p. 526). In other words, adolescent Black boys, not viewed in the same light as their white peers, are more likely to be mistaken as older and face violence from police who automatically perceive them guilty of any crimes for which they are accused. These researchers tested 176 police officers and reviewed their personnel files to examine use of force on duty as a part of this study. They found that police officers who dehumanized Blacks 
were more likely to have used force against a black child in custody than those officers who did not dehumanize Blacks. Kahn and McMahon (2015) discovered in their own study of police officers that "these shooting decisions can be affected by automatic processes involving stereotypic associations between racial groups and criminality and aggression” (p. 312). The culmination of these fears of Black men are significant because they influence the Black administrator lived experience at HWIs.

\section{Space Traders}

In Derrick Bell's acclaimed book, Faces at the Bottom of the Well, he told an intriguing story in his chapter entitled Space Traders. A visiting spaceship comes to America filled with gold, special chemicals for unpolluting the environment, and a nuclear engine and fuel. In exchange for these valuable commodities, the space traders only wanted all of the Black people living in the United States. The date was set for their departure on the observation of Dr. Martin Luther King Jr.'s birthday. In the days preceding the deadline, the country was split between saving America with the treasures being offered or keeping the Black people in addition to the pre-existing problems. As the President's cabinet convened, with only one conservative Black person at the table, the allure of the space traders' offers continued to gain momentum. The President retorted, “they are offering not only a solution to our nation's present problems but also one--surely an ultimate one--to what might be called the great American racial experiment" (Bell, 1992a, p. 164). This statement gave permission for the Secretary of Health and Human Services and the Attorney General to propose using the selective service legislation to send Black people away with the space traders as an act of American patriotism.

When the time came for Professor Golightly's, the token Black representative on the extended cabinet of the President, perspective on the offer, he explained the following: 
As you know, Mr. President, I have supported this administration's policies that have led to the repeal of some civil rights laws, to invalidation of most affirmative action programs, and to severe reduction in appropriations for public assistance. To put it mildly, the positions of mine that have received a great deal of media attention, have not been well received in African American communities. Even so, I have been willing to be a 'good soldier' for the Party even though I am condemned as an Uncle Tom by my own people .... I disagree strongly with both the Secretary of the Interior and the Attorney General. What they are proposing is not universal selective service for Blacks. It is a group banishment, a most severe penalty. (p. 166)

Despite his best efforts, Golightly was outnumbered, and the President's administration moved forward crafting legislation in support of selective service for Black people only that would require them to go with the space traders. This was a disappointing moment for Golightly because he considered himself an insider. He only supported the President's agenda in the past because it gave him advantages behind the scene to support additional funding for Black schools and prominent appointments for Black leaders. He used his status as a token to negotiate access to power for Black people. There was no winning this time. In spite of many protests from both Black and white people, the selective service legislation passed with $70 \%$ of Americans in favor and 30\% of Americans in opposition. On the observation of Dr. Martin Luther King Jr.'s birthday, all of the Black people in America were stripped, chained, and led on the spaceships: forced to leave as their ancestors had arrived.

The chapter on space traders is the perfect illustration of anti-blackness in action: the thingification and commodification of the Black body. The truth is the fate of the Black people 
was solidified before Professor Golightly walked into the space. Initially, he did not have a seat at the table; he was invited in as an extended friend of the Cabinet. His selection was based on past decisions he supported that made him appear to be a token among many other Black people.

He vocalized his concerns before the Cabinet; however, he did not have any capital and influence to sway anyone in the room. Mitchell (2017) said, "Without a Black voice at the table where decisions are made, 'business as usual,' white privilege, and power continue to exist”' (p. xx). The country had been looking for a way to eliminate Blackness. When the opportunity presented itself, their actions were driven by their anti-black ideology.

\section{Anti-blackness in Higher Education}

It is important to note the anti-black ideology of superiority and the practice of inequity naturally began to mirror itself within institutions of higher education initially through slavery. Wilder (2013) declared that higher education, along with church and state, were built on bondage of American slavery. One of the ways institutions of higher education benefitted from slavery was through the money made from the trans-Atlantic slave trade and colonial plantations. Thelin (2011) said, "An important, relatively quiet change in American higher education between 1850 and 1890 was the increasing influence of substantial philanthropy. Large gifts, often in the form of foundations, trusts, and estates, became a potent vehicle for innovation" (p. 100). Another way institutions of higher education benefitted from slavery was by having slaves build and run the daily operations of them. Black people were present at the birth of higher education; unfortunately, we were not in the classrooms. Wilder (2013) provided a thorough account of the depth of the enslaved people's work in the following passage:

In the daily routine of a college there was a lot of work to be done, and enslaved people often performed the most labor-intensive tasks. In the mornings, the 
professors and scholars needed wood for fires, water for washing, and breakfast after morning prayers in the chapel. As students ate, their rooms were cleaned, chamber pots emptied, and beds made. Ashes needed to be cleared from fireplaces and stoves, and floors needed sweeping. Clothes and shoes were cleaned and mended. Fires were lighted and maintained. Buildings wanted for repairs, and servants were impressed into small- and large-scale projects. There were countless errands for governors, professors, and students. (p. 134)

Keeping institutions of higher education operational required the availability of slave labor. However the exploitation of slave labor alone was not the only instrument used in the progression of these institutions. Thomas Jefferson called upon intellectuals in higher education to legitimize theories of white superiority and Black inferiority (Wilder, 2013).

The knowledge and ideas constructed in higher education "refined and legitimated the social ideas that supported territorial expansion" (Wilder, 2013, p. 182) and dehumanizing slavocracy. According to Wilder (2013), the founder of the College of Philadelphia, Benjamin Franklin, held the belief that Africans diminished the power and status of white America. To lessen the impact of Blackness [Africaness] he argued that they should be excluded. Franklin believed that the white purity of America could be accomplished through landownership and continued education. This inherent belief about Blackness was infused into the knowledge materialized from higher education. In fact, some of the first "research" produced by colonial intellectuals lauded the superiority of whiteness and the inferiority of Blackness in mind, body and soul (Wilder, 2013). This research was used to justify the continued exclusion, mistreatment, and bastardization of Black bodies.

Scientific racism was used to render intellectual proof of the Black inferiority by 
experimenting on Black bodies (Washington, 2016; Wilder, 2013). Anti-black ideas assumed Black bodies were impervious to pain; therefore, they were mutilated, dismembered, and debased to test medical theories and assumptions. The findings of these research studies achieved Jefferson's call for knowledge construction and advanced anti-blackness from the university to legitimatization of white supremacy as logical and reasonable. Institutions of higher education gained prestige, academic legitimacy, and financial security at the expense of Black bodies. Institutions like the University of Virginia, Harvard University, University of Mississippi, and Brown University are a small delegation that have recently acknowledged and are doing additional research on their respective legacies of slavery; however, none of this negates the antiblack violence against Blacks at HWIs. Even at the conclusion of slavery, Dumas (2016) divulged the following revelation that reinforces the pervasiveness of anti-blackness:

There is no clear historical moment in which there was a break between slavery and acknowledgement of Black citizenship and Human-ness; nor is there any indication of a clear disruption of the technology of violence--that is, the institutional structures and social processes--that maintain Black subjugation. (p. 14)

The truthfulness of this statement is revealed in the way Blacks were treated in the aftermath of slavery.

Newly freed Black people went from slavery to regulated second-class citizenship in America. "Prior to World War II, African American faculty and administrators were deliberately excluded by law, custom, or tradition from predominantly white universities" (Wright, Taylor, Burrell, \& Stewart, 2006, p. 58). The Plessy v. Ferguson (1896) outcome gave birth to the separate but equal doctrine. Homer Plessy was arrested for refusing to ride a colored only train in 
Louisiana. Though he argued, his 13th and 14th amendment rights were violated, Plessy discovered what many Black people would soon come to learn that a system cannot fail those it was never built to protect. The 13 th amendment was ratified in 1865 , abolishing slavery and involuntary servitude except as punishment for a crime. The 14th amendment was ratified in 1868. It acknowledged people born or naturalized in the United States as citizens as well as promised not to deny any person within its jurisdiction the equal protection of the laws.

Language, in the way that it is presented, can be a tricky thing. Phrases such as "except or within its jurisdiction" leave room for unlikely interpretations. The Supreme Court ruled against Plessy and declared that as long as entities were equal in the design and delivery of services, it was legal to allow Blacks to only frequent spaces designated as "colored" sections. This decision provided the justification white institutions needed to refuse to hire Black faculty and administrators (Wolfe \& Dilworth, 2015). However, Black faculty and staff were able to teach at HBCUs and most Black students were able to obtain their education from HBCUs. In addition, some of the affluent Black students could afford to attend prestigious white institutions.

It is disappointing to think about the 50 plus-year stronghold segregation had in this country before the Brown v. Board of Education (1954) Supreme Court ruling. Mustaffa (2017) spoke to this phenomenon:

From the Black Codes to Jim Crow, these legal structures in the North and South denied Black people's constitutional rights and subjected them to white terrorism through lynching, dehumanizing de facto and de jure policies, education exclusion, and extreme wage exploitation. (p. 716)

Segregation is often referenced based on the separation of Blacks from whites; however, this does not capture the depth of the exclusion. Through segregation, Blacks were excluded 
from governmental funding and resources that were afforded to white institutions only (Mustaffa, 2017). The second Morrill Act of 1890 failed to provide Black institutions the 17.5 millions of acres of land and millions of dollars the Morrill Act of 1862 allocated to white institutions. Furthermore, the G.I. Bill of 1944 cut Black people off from homeownership, which is directly linked to wealth building and well-resourced schools (Mustaffa, 2017). This exclusion argument is critical because Black people called for desegregation as a means to access equitable resources and not necessarily for integration.

Unfortunately, Brown v. Board of Education (1954) was not quite the redeeming feature many had initially hoped. Valverde (2003) raised attention to the decision that called for schools to be desegregated with all deliberate speed; however, most institutions were found noncompliant until the early 1980s. This language loophole left room for institutions to make slow progression towards true integration. In 1964, Title IV of the Civil Rights Act prohibited discrimination based on color, race, or natural origin. Title VII of the same act barred discrimination in employment. In 1965, President Lyndon B. Johnson issued Executive Orders 11246 and 11375 , which introduced affirmative action to provide equal opportunity in employment for minority groups and women (Wright et al., 2006). C. Smith (1980) emphasized that hiring of Black administrators in the 1960s started out of the combination of violent threats from the Black community, especially Black students, and the federal government's threat to withhold institutional funds for lack of compliance to the newly enacted laws created to prevent discriminatory practices. With that, Black administrators were given access to white spaces in higher education.

From the 1600s through the Jim Crow era, the learned community focused much of its intellectual energies on the social construction of whiteness as supreme juxtaposed with idea that 
Blackness is logically and reasonably inferior. Anti-black epistemology became the curriculum core that structured American intellectualism (Wilder, 2013). Today, despite the strides taken to increase our [Blacks] presence within the academy, the ideological stronghold of anti-blackness preserves the practice of inequity and gives the illusion of normality. Anti-blackness is the unspoken justification for whiteness. "The academic community is filled with discrimination and racism . . .. Blacks perceive it as always being there; like relative humidity, it is present, penetrating, oppressive, encompassing, and pervasive” (Moore \& Wagstaff, 1974, p. 205). However, much debate exists on whether the academy consciously produces discrimination or racism; however, the intent really does not matter. The literature shows that institutions of higher education continue to use and perpetuate anti-blackness and discrimination through its research, policies, and practices (Moore \& Wagstaff, 1974).

\section{Blackness}

Black is King! This bold declaration was brought to life by the critically acclaimed singer Beyonce Knowles-Carter. This project was a visual album that highlighted various forms of Blackness. Dumas (2016) defined Black as "a self-determined name of a racialized social group that shares a specific set of histories, cultural processes, and imagined and performed kinships" (p. 12). Blackness is too many things to be anything but everything; existing in the state of being and based on the perception of the eye of the beholder (Wright, 2015). This dissertation was undertaken by me to disrupt and dismantle anti-blackness, and it cannot be achieved without Blackness. Blackness is the cure to anti-blackness. To accomplish this phenomenon, we have to marvel the exquisiteness of our resistance. Consider the following statement from Wilderson (2010):

The violence that turns the African into a thing is without analog because it does 
not simply oppress the Black through tactile and empirical technologies of oppression, like the 'little family quarrels' for which [Frantz] Fanon the Jewish Holocaust exemplifies. Rather, the gratuitous violence of the Black's first ontological instance, the Middle Passage, 'wiped out [his or her] metaphysics ... his [or her] customs and sources on which they were based' .... This violence which turns a body into flesh, ripped apart literally and imaginatively, destroys the possibility of ontology because it positions the Black in an infinite and indeterminately horrifying and open vulnerability, an object made available (which is to say fungible) for any object. (p. 38)

Wilderson (2010) made a point to reiterate that Africans went in slaves ship and came out as Black. The concept of Blackness was birthed in the stripping of our heritage: a human and metaphysical holocaust (Wilderson, 2010). Despite everything that has happened to Black people, Blackness in all of its glory could not be destroyed.

Wright (2015) conveyed the following point, which sets the stage for defining Blackness in terms of today:

The only way to produce a definition of Blackness that is wholly inclusive and nonhierarchical is to understand Blackness as the intersection of constructs that locate the Black collective in history and in the specific moment in which Blackness is being imagined--the 'now' through which all imaginings of Blackness will be mediated. (p. 14)

Much pushback has come from the doom and gloom fog cast on Blackness by afropessimism. In spite of everything endured by people of African descent, Blackness continues to persist and resist in incredible ways. An emerging collection of ideas by many 21 st century scholars is being 
referred to as critical Afropessimism (Grant et al., 2019; Ross, 2019). These scholars, like the traditional Afropessimism scholars, agree that Black humanity may never be gained in these systems; however, the difference is connected in the belief that Black humanity is an ontological reality--we are already enough (A. Woodson, 2019). There is no need for Black people to seek justification from the places and spaces occupied. These kinds of ideas invite scholars to ask different questions and to reimagine ways of seeing the Black experience. This critical afropessimism approach recognizes both "the violence of the plantation and its afterlife while simultaneously acknowledging the ongoing capacity for the making and remaking of Black life in the midst of plantation violence" (King, 2016, p. 1023).

\section{Summary}

In this chapter, I established the foundational underpinning of anti-blackness. I described how it is manifested in relation to the Black body, specifically that of the Black man. It was important to dive deeper into the origins of anti-blackness in higher education and reveal its prevalence to racism. I used the space traders to illustrate the intent of anti-blackness as an ideology to suppress and eliminate the presence of Blackness. Finally, I briefly highlighted Blackness and critical afropessimism to demonstrate the necessity of centering Blackness in any discussion about anti-blackness. In Chapter III, through an extensive literature review, I describe my guiding frameworks and the relevant literature on Black administrators. 


\section{CHAPTER III: LITERATURE REVIEW}

The purpose of this study was to unmask the ways that senior-level Black administrators process, navigate, and make meaning of their lived experiences and anti-blackness at HWIs. The review of literature begins with an in-depth rationale on two guiding frames for this study: BlackCrit and Marginality and Mattering. Understanding these guiding frameworks established the foundation necessary for this study. The problems faced by Black administrators, the recruitment and retention of Black administrators, tokenism, and the underrepresentation of Black administrators are the critical areas in this section.

\section{Frameworks}

A frame is a set of ideas and assumptions that you carry in your head to help you understand a particular thing (Bolman \& Deal, 2017). Incorporated into this study were dualistic guiding frameworks, BlackCrit and theory of marginality and mattering. Together, these frameworks comprehensively highlight the lived experiences of Black men administrators in higher education.

\section{BlackCrit}

In 1970, Dr. Joseph White who was known as the godfather of Black Psychology, wrote a groundbreaking article for Ebony Magazine. White boldly declared the following:

It is vitally important that we develop out of the authentic experience of Black people in this country [United States], an accurate workable theory of Black psychology. It is very difficult, if not impossible, to understand the lifestyles of Black people using traditional theories developed by white psychologists to explain white people. Moreover, when these traditional theories are applied to the lives of Black folks many incorrect, weakness-dominated and inferiority oriented 
conclusions come about. (p. 45)

His article was instrumental in beginning the modern era of black and ethnic psychology because it helped to define and frame the discourse. This was not the first time that leading voices were influential in the creation of new methods of theorization.

"The critical race theory (CRT) movement is a collection of activists and scholars engaged in studying and transforming the relationship among race, racism, and power" (Delgado \& Stefancic, 2017, p. 3). CRT emerged in 1970s as the byproduct of legal scholars and activists searching for strategies to combat racism. CRT builds on critical legal studies and radical feminism. Derrick Bell, an attorney and professor, was one of the leading authors of the foundational CRT works. His articulation of the permanence of racism in America and the introduction of the concept interest convergence are cornerstones of how CRT is situated today. CRT transitioned into the field of education by way of Gloria Ladson-Billings and William Tate's 1995 trailblazing article called "Toward a Critical Race Theory of Education.” They believed that CRT in education would expose the deeply ingrained epidemic known as racism that haunts American life. More important, they sought to develop a blueprint for scholars to theorize race in such a way that we could reimagine how we currently see and do things.

In conjunction with the demand for Black Psychology and CRT in education, the time has come for the birth of a different conceptual perspective in education--BlackCrit. BlackCrit is a theory of blackness that confronts anti-blackness as a social construct and a lived experience of suffering and resistance. It is a critical analysis of the administration of laws or policies designed to subjugate Black people in the United States (Dumas \& Ross, 2016). One of the main reasons I am pursuing this study through the lens of BlackCrit is explained by Dumas and Ross in the following critique: 
BlackCrit becomes necessary precisely because CRT, as a general theory of racism, is limited in its ability to adequately interrogate what we call 'the specificity of the Black.' That is, CRT is not intended to pointedly address how anti-blackness--which is something different than white supremacy--informs and facilitates racist ideology and institutional practice. More, it cannot fully employ the counterstories of Black experiences of structural and cultural racisms, because it does not, on its own, have language to richly capture how anti-blackness constructs Black subjects, and positions them in and against law, policy, and every day (civic) life. (p. 417)

Although Dumas has been instrumental in introducing this concept into education, it is important to note the roots of the theory comes from Africana studies. The best way to describe BlackCrit theory is to center everything on Blackness. Mustaffa (2017) coined the phrase Black life making as a means to disrupt anti-blackness through the practice of self-authorship and self-care. What BlackCrit provides is a unique opportunity to claim blackness as a site of empowerment, resistance, and agency (Dei, 2017).

A major tenet of BlackCrit is the prevalence and pervasiveness of anti-blackness. Too often, black experiences are viewed, critiqued, and communicated juxtapose to any and everything except blackness. "The aim of theorizing antiblackness is not to offer solutions to racial inequality, but to come to a deeper understanding of the Black condition within a context of utter contempt for, and acceptance of violence against the Black" (Dumas, 2016, p. 13). The incorporation of BlackCrit would make my study unique because it positions Black administrators to speak truth to power by shedding light on the lived experiences at HWIs to yield deeper reflections and responses. Bell (1992b) led with this important perspective that must 
be factored in when exploring the Black administrator's experience:

Black people will never gain full equality in this country. Even those herculean efforts we hail as successful will produce no more than temporary 'peaks of progress,' short-lived victories that slide into irrelevance as racial patterns adapt in ways that maintain white dominance. This is a hard-to-accept fact that all history verifies. We must acknowledge it and move on to adopt policies based on what I call 'Racial Realism.' This mind-set or philosophy requires us to acknowledge the permanence of our subordinate status. That acknowledgement enables us to avoid despair and frees us to imagine and implement racial strategies that can bring fulfillment and even triumph. (p. 374)

From Bell's perspective, there is an opportunity to empower oneself through accepting the totality of our racial status. Racial realism does not mean giving up hope of change and progress in America. In fact, it means the opposite; one cannot hope for change or progress without setting strategies and priorities that are rooted in the reality instead of the delusions of what is hoped. Furthermore, facing the realities about Black racial identity in higher education positions use to be better suited to diagnose what it means to be Black administrators navigating white spaces, which are steeped in anti-black racism. In the future, this study will be attributed to creating liberating opportunities to empower future leaders in the academy.

The opportunity to explore the lived experiences of Black administrators in white spaces through this lens because it mandates a new path rooted and led in Blackness. As in the declaration of Moore and Wagstaff (1974), this study is designed to be the following:

Discriminatory, biased, and prescriptive. It is discriminatory because it focuses primarily on Black educators [as administrators]. It is biased because it reports 
and discusses only the perceptions of Black faculty members and administrators in predominantly white colleges and universities. It is prescriptive, we hope, because it provides information and techniques that may be used by the academic [and higher education] community in attempting to relate to its newest members, Black educators. (p. ix)

This is significant because this study sought to make a meaningful contribution to higher education, critical race studies, and critical education studies - areas that have not been adequately critiqued in anti-black discourse and its presence within their respective fields. By using BlackCrit as one of my guiding lenses, I am not researching whether anti-blackness against Black administrators at HWIs exists, but rather how Black senior-level administrators thrive in spite of its existence. Furthermore, "Black identity is affirmed both as a racial consciousness and political awareness of what it means to be Black in a white-dominated society and the resistances that are required for Black survival" (Dei, 2017, p. 67). This profound statement captures the core and spirit of my study. I seek to understand how Black administrators in white dominant spaces navigate and disrupt anti-black ideologies, policies, and practices.

\section{Theory of Marginality and Mattering}

Schlossberg (1989), a higher education practitioner, introduced the theory of marginality and mattering as a way to determine how students were creating community at colleges and universities. It was about exploring inclusion through navigating feelings of marginality and mattering. Marginality can be experienced when people are in transition and feel they do not matter. The state of being marginalized can be a temporary or a permanent condition. Like Pinderhughes (1989), Schlossberg references biculturalism to explain the feeling of a person feeling lodged between two worlds. Black administrators in HWIs know what it is like to be in a 
state of two-ness (i.e., between two worlds). The result is the physical feeling of dissonance, which DuBois called double consciousness. Whether it is referred to as masking or code switching, the aftermath leads to feelings of marginality--fragmentation and confusion. The state of marginality can also leave one feeling invisible or isolated. "Institutional racism, cultural insensitivity, and marginalization are just few of the manifold encumbrances that define the experience of an African American administrator at predominantly white colleges and universities" (Guillory, 2001, p. 113). This statement is directly applicable as this theory is evolving as researchers examine how institutions make their constituents (i.e., Black administrators) feel they matter. Black administrators who are tokenized or hired into positions that lack power are predisposed to be marginalized.

Rosenberg and McCullough introduced the idea of mattering in 1981 through their research on adolescent feelings of mattering and their likelihood to commit delinquent acts. Mattering refers to the belief, whether real or imagined, that we count to other people (Schlossberg, 1989). An important element of mattering is its motivating factor in determining behavior. When people feel they belong, they do not feel marginal. In his examination of Black male collegians' sense of belonging at HWIs, Strayhorn (2012) found that engagement in purposeful activities foster a sense of mattering for them along with positive interactions and a welcoming racial climate on campus. Like Black male collegians, Black administrators are seeking a similar sense of belonging on campus. Unresolved feelings of marginality are not healthy for any growing community. The final component of Schlossberg's theory is helping people deal with marginality through the utilization of rites of passage, which is the transition of one phase of life to another. This means creating rituals or ceremonies throughout the career trajectory of a Black administrator at an institution to reinforce his or her sense of mattering and 
belonging.

This study explored the ways that senior-level Black administrators used the rites of passage throughout the course of their career. These ceremonial changes stimulate Black administrators despite their marginalizing experiences within their roles. This framework allows me to discover, through their articulated experiences, how these Black men make meaning of the work, their worth, and their pitfalls. Furthermore, one of the frameworks of this studymarginality and mattering--is for the first time, focusing on higher education administrators instead of college students.

\section{Problems Faced by Black Administrators}

Administration positions were created for white people. More specifically, the original intent and design of those roles were for white administrators to take those positions to support white students at their institutions. The 1940s through the 1960s saw a significant shift of college access because of both the G.I. Bill of 1944 and the Supreme Court's Brown v. Board of Education (1954) decision to desegregate public education. This legislation supported an influx of students, including students of color, into HWIs. This integration began to create different kinds of problems that had not been traditionally experienced by these institutions. In the wake of the growing enrollment of students came the demand for the expansion and diversification of the faculty and administration. Unfortunately, this demand was often not the proactive decision of the HWI administrators. New administrative roles for Black professions were the result of relentless campus demonstrations and protests by Black students. "Between 1968 and 1972, responses to Black student demands for Black faculty and Black administrators helped to dot and occasionally sprinkle the white landscape of the academe with minority newcomers" (Hale, 1975, p. 46). Whether a HWI directly experienced these student protests or heard about them 
from their colleagues at neighboring institutions, Black administrators began to emerge at HWIs across the country.

In 1978, Samuel Woodard began to notice what he described as the "stress and strain" college administration was having on Black administrators. Woodard was a Black administrator at Temple University at the time and was becoming increasingly concerned by what he was hearing from his fellow Black colleagues in administration. He knew something had to be done. S. Woodard (1978) decided to organize an interdisciplinary stress reduction conference specifically for Black administrators that would have been the first of its kind. Unfortunately, the manifestation of this conference never happened. Instead, Woodard decided to publish a book entitled Reducing Stress on Black Administrators that would address salient issues Black administrators had been experiencing in higher education. He thought that by giving voice to these experiences, it would reduce the circumstances and barriers that were causing such stress. M. C. Woodard and Harris (1978) believed the following nine factors accounted for the stress and strain experienced among Black male administrators as opposed to their white male counterparts:

(a) A compulsion to prove himself to white as well as Black people, which involves different kinds of proof often of a conflicting nature; (b) a feeling of pressure by circumstances to learn and succeed quickly; (c) frustrations stemming from conscious and unconscious inexperience; (d) a feeling that his presence in a high position ought to make a difference in terms of public policy priorities that would improve the lot of his people; (e) a general unfamiliarity with the principles, norms, customs, procedures, and routines of administrative and bureaucratic life, particularly, in terms of meshing these elements with the social and psychological factor of his Blackness; (f) in some cases, a 
lack of basic and special information needed to operate effectively; (g) inability to organize effectively to avoid 'busy work' that minimizes the time available for a thorough assessment of long-range goals, and for planning of appropriate strategies; (h) demands and expectations of Black constituents are often amorphous, incoherent, inarticulate, conflicting, and contradictory; and (i) disharmony between expectations of white and Black constituents. (p.16)

From the onset, there was an imbalance created between Black and white administrators that makes success and failure for them look significantly different. In addition, Black administrators are underrepresented and are more likely to serve in less prominent leadership positions than their white counterparts (Mitchell, 2017).

One thing to note about these nine factors is they are all in addition to the primary job responsibilities required of Black administrators within their roles. The Black administration experience means figuring out what to do about those other duties as assigned. Judson (1999) experienced this firsthand as he recalls the invitations, requests, standing committees, task forces, speeches, adjudications, boards, mentoring requests, and ad hoc committees presented to him based solely on his being a Black administrator. Participation in these commitments are important; however, collectively, these activities can become time consuming. Black administrators thrust into these positions without previous experience in administration might struggle with prioritizing these offers in conjunction with the required items directly aligned to the position. Unfortunately, the Black administrator's experience appears to be one of baptism by fire. In other words, they are forced to learn as they go within the position without any proper training or onboarding. Literature on this subject is limited, but what does exist depicts a disparaging view of what Black administrators experience. 


\section{Bamboozled: Access to Power Without Being Empowered}

You do not know what you do not know. Black administrators are brought to campus for an interview. The series of events consist of structured interview sessions with various campus partners, individual interviews with critical people with whom the successful candidate will work closely, and presentations geared towards seeing if this candidate would be a good fit for the role and institution. The term fit is a code word often used to denote "not like us." It is a form of antiblackness used to exclude instead of create access. T. Anderson (1988) noted how search committees have been able to evade equal opportunity and affirmative action policies through unjust and superficial screening in the evaluation of Black applicants. Furthermore, the basis of exclusion is codified through language such as organizational fit where it is used to remove potential Black candidates from faculty and administration search processes. As the institution's administrators present their best selves, so does the interested candidate. At the end of every session, the candidate is asked about questions that he or she might have. The interview process is over. Weeks or months go by without a decision. Then suddenly, the Black administrator is hired. The larger revelation of what he or she might encounter has yet to be revealed. Shortly afterwards, the Black administrator is confronted with anti-blackness as the reality that their position is haunted by problems that predate their arrival. Just like that, the Black administrator is beginning to put the pieces together that they were not necessarily hired into the position to be successful. They were bamboozled.

Vincent Tinto, Professor Emeritus at Syracuse University and retention expert once told me that, "access without support is not opportunity" (V. Tinto, personal communication, October 15, 2013). There are no clear pathways to university administration. In fact, most Black administrators are not informed about their level of performance until something is wrong. 
Additionally, no formal training to prepare one for this kind of leadership role exists. Research or literature written about the Black administration experience that could be used as a blueprint to navigate the terrain is limited. Black administrators are overworked, tokenized, and marginalized (Mitchell, 2017; Wiley, 2001; Wolfe \& Dilworth, 2015; Wright et al., 2006). Jackson and Flowers (2003) affirmed these declarations in the following statement:

PWIs should be cautious not to set someone up for failure by delegating assignments to and/or placing African Americans in positions in which they do not have the appropriate aspirations, skills, abilities, or potential. These conscious and unconscious set-ups can be professionally and personally demoralizing. (p.

Denzel Washington portrayed Malcolm X in Spike Lee's (1992) biographical film. At one point in the movie, Malcolm X says, "Oh, I say and I say it again. You have been had! Ya been took! Ya been hoodwinked! Bamboozled! Led astray! Run amok! This is what he [whiteness] does!" This statement could represent what Black administrators think about their lived experiences in white spaces--a set up for failure.

\section{Good for You, Not for Me}

W. E. B. DuBois (1906) declared, "The Negro death rate and sickness are largely matters of [social and economic] condition and not due to racial traits and tendencies" (p. 90). Even in 1906, DuBois understood that the conditions that Black people were experiencing in America were having a negative effect on their overall well-being. This is something that higher education administrators has to come to terms with as it pertains to Black administrators. W. Smith et al. (2011) made this vital point in relation to this matter:

Social, educational, and professional institutions, such as society-at-large, must 
realize that there is an emotional, physiological, and psychological cost of engendered racism. These experiences shape identities, motivations, dreams, activities, and the psychological and physiological welfare across the personal and professional lifespan of women and men of color. (p. 64)

Wolfe (2013) cited feelings of powerlessness, tokenism, unrealistic role expectations, and inhospitable campus environments as reasons many Black people in higher education want to leave. What continues to go undiscussed or acknowledged is the cost that taxation, marginalization, and racism has on Black administrators. W. Smith et al. (2011) described racerelated experiences in historically white spaces as mundane extreme environmental stress or MESS. In other words, the magnitude of the visible and subtle racism in the work environment not only generates stress but also influences one's physical, spiritual, and emotional reactions in ways often unnoticed or ignored. Racial battle fatigue was developed as a comprehensive mechanism to explain the weight that oppressive, systemic conditions of racism have on historically marginalized groups (Perry \& Pickett, 2016). Studies show a correlation between workplace discrimination and adverse outcomes (e.g., job stress, job dissatisfaction, burnout), but they also link a clear empirical relationship with symptoms of psychiatric disorders (e.g., depression, anxiety) and poor health conditions (Perry \& Pickett, 2016). As Black administrators entered employment with HWIs in 1960s and encountered dissonance in the workplace, S. Woodard (1978) recognized the same concern about the stress and strain experienced by Black administrators a decade later.

\section{Recruitment and Retention of Black Administrators}

Eighty-six percent of the administrators in higher education are white and 7\% are Black (Bichsel \& McChesney, 2017). A national study conducted between1976-1977 found that 457 
Black administrators were employed by HBCUs and HWIs (Hoskins (1978). In the Fall 2013, there were 242, 335 administrators from all institutions. From this total, 23,532 (9.7\%) were Black and 188,729 (77.9\%) were white. In the fall 2016, there were 254,979 administrators from all institutions. From this total, 25,553 (10.0\%) were Black and 193,290 (75.8\%) were white (The Chronicle of Higher Education, 2018b). Between Fall 2013 and Fall 2016, employment of Black administrators increased by $0.3 \%$ of Black across all institutions. From 1976 to 2016, Black administrators went from 457 to 25,553. Based on these statistics alone, "there is no clear evidence that colleges have made a total commitment to achieving a diversified student body, faculty, and administration” (Hale, 1975, p. 46). In fact, Mitchell (2017) pointed out how ridiculous it is that two decades into the new millennium, scientist are preparing to crash test self-driving cars on the planet Mars; however, colleges and universities are still struggling to diversify and integrate the faculty and administration.

\section{Defining Administrators}

When defining administrators, it is important to begin with the realization that the following official titles and hierarchical changes of command are standardized by whiteness. "The term university administrator refers to an individual in a managerial or policy-making capacity that may have a line or staff function" (Wolfe, 2013, p. 25). Jackson (2001) noted three administrative specialty levels in higher education: academic affairs, student affairs, and administrative affairs. Examples of roles within academic affairs are president, provost, academic dean, and department chair. Roles within student affairs include vice president for student affairs, dean of students, and director of financial aid. The vice president for finance, director of alumni relations, and director of institutional technology make up the specialty level of administrative affairs. These designations are important because the path to presidency at an 
institution are linked primarily to academic affairs. To offer a different perspective on the power dynamics of administrative levels, Valverde (2003) identified two administrative tracks for persons of color in higher education: mainline or sidetracked. He described these tracks as follows:

Mainline roles are the traditional titles such as president, vice president, dean, director, and department chair. Sidetracked roles are a combination of traditional and stereotypical elements: traditional--special assistant to the president, associate vice president, assistant dean--or stereotypical--director of affirmative action, chair of ethnic studies, associate vice president for minority student recruitment, and the like. (p. 43)

Jackson (2001) agreed with Valverde (2003) who said that Black administrators are often brought into roles not considered mainstream or having power. Curriculum development, admissions, and faculty qualifications are key responsibilities within academic affairs and that makes it an essential component of the university experience (Jackson, 2001). These position descriptions are presented differently through the functionalities of line officers versus staff officers. C. Smith (1980) described line officers as "managers with administrative authority and direct responsibility for personnel, budget, and programs related to major goal activities. They are a part of the administrative hierarchy of the organization" (p. 325). Staff officers tend to reside in positions outside of the administrative hierarchy because their power and authority comes from their area of expertise. These positions can sometimes operate in consultation with and at the pleasure of line officers. From this perspective, the success of a Black administrator lies heavily on his or her ability to influence line officers to use and implement his or her recommendations based on the knowledge exhibited on given issues. This is the lifeblood of an 
institution's functionality since these recommendations are linked directly to the overall enrollment and finances generated.

\section{Recruitment}

During the 1960s, administrators from HWIs began recruiting Black administrators. Hoskins (1978) referred to the concept of brain drain, which was the process of luring Black scholars away from HBCUs. This practice was problematic for a number of different reasons. First, it removed Black scholars from their roles as faculty members into administrative roles. This action decreases the number of Black faculty who influence the curriculum for an institution. Considering the low numbers that already exist for Black faculty, it creates an imbalance in having representation throughout higher education. In addition, this practice creates competition, which makes it difficult to build community among an already limited number of Black people with a Ph.D. Supporting and mentoring other Black professionals becomes less appealing when one starts to see the other person as a direct threat to their future opportunities because desired positions are scarce. Furthermore, Judson (1999) saw HWI administrator's raiding HBCUs for Black scholars as taking the easy way out. To clarify, if Black scholars choose to pursue these opportunities on their own, then that is not a problem because they are looking for a different experience. Nevertheless, the challenge lies in the manner that these administrators recruit and hire Black talent.

An additional component to the recruitment of Black administrators is the scarcity of qualified Black candidates. University administration positions often require a Master's degree or a terminal degree (i.e., Ph.D., Ed.D., J.D.). "This challenge is that there are not enough Black students in the 'pipeline'--students achieving bachelor's and master's degrees--to produce enough students at the doctoral level" (Simmons, 2017, p. 125). Furthermore, Black people with terminal 
degrees are enticed from higher education by corporate entities, governmental and non-profit agencies, and private consulting firms. In comparison to other industries, higher education does not provide comparable and equitable compensation packages.

\section{Retention}

Davis (1994) maintained that Black administrator retainment is an outward display of diversity that many institutions claim to espouse.

The true test of institutional commitment to diversity should not be measured by the number of minority students on campus, but through the number of senior-level administrators of color staying at an institution with a tenure of four or more years" (p. 3) However, current statistics on Black administrators does not demonstrate a real commitment to their retention. Higher education administration is comprised of 7\% Black administrators and 86\% white administrators (Bichsel \& McChesney, 2017). The lack of retention among Black administrators continues to be an issue because it reveals a behind-the-scenes discourse that permeates an institution in both unseen and unwanted ways (Wiley, 2001). In other words, the length of time a Black administrator is employed at an institution is based solely on how an institution can or cannot address the barriers of retention that exist within its environment.

The literature review did not reveal a standard method of evaluating retention or success for administrators. Students matriculate to complete a degree program (e.g., undergraduate, graduate, and professional school) and faculty members are working to achieve two outcomes: securing tenure status and upward progression through professoriate progression (Jackson, 2001). Unlike students and faculty, university administrators lack a clear promotion system for position advancement. Additionally, defined pathways to university administration are vague. Oliver and Davis (1994) shed light on the lack of preparatory options (i.e., leadership 
development seminars or management workshops) available for people of color looking to become administrators. Jackson (2001) expounded on this point by identifying barriers to retention among Black administrators as lack of professional identity, low compensation, lack of career path, and working conditions. These barriers cause Black administrators to seek opportunities where they become available, even though it might mean switching institutions or relocating to another state or country: notwithstanding the various levels of racism, either direct or vicarious, that Black administrators experience at HWIs.

Hoskins (1978) conducted a study of Black administrators at HWIs and HBCUs. He looked at the variables that are considered most important to their success and longevity. In his findings for Black administrators at HWIs, the variables were the combination of poor relationships, institutional racism, and higher promotiomal standards required of Black administrators when compared to their white counterparts made them want to leave their current institutions within the next few years. These findings are consistent with the established 5-year milestone for many Black administrators working in an institution with a commitment to diversity (Davis, 1994; Jackson, 2001). There is much more work needed to better retain Black administrators in higher education.

\section{Tokenism}

Within the context of higher education, Black administrators are consistently compared to window dressers or tokens (Brooks \& Arnold, 2013; Comer, 1978; Davis, 1994; Durgans, 2002; Harvey, 1999; Lee Jones, 2001; Valverde, 2003; M. C. Woodard \& Harris, 1978). The origin of this parallel goes back to the 1960s when Black administrators were hired at HWIs. "Higher education's institutional violence first excluded Black people based on the need for slave labor, then granted access based on segregation, and expanded access based on tokenization" 
(Mustaffa, 2017, p. 722).

Harvey (1999) pointed out that racial discrimination is deeply engrained in American colleges and universities and it has shown itself through the lack of equal consideration for positions of power and authority, except in very isolated situations, for Black people at HWIs. The selection of Black administrators has come not only because of the implications from the Brown v. Board of Education (1954), but also through the passage of the Civil Rights Act of 1964. Title VII of the Civil Rights Act prohibits employers from discriminating against employees based on race, color, sex, religion, and national origin. To avoid violating equal opportunity and affirmative action laws, T. Anderson (1988) proclaimed that white institutions created assistant and associate positions geared towards giving the illusionary effect of Blacks occupying administrative roles within the institution. "Instead, for them, it was more an appearance they should demonstrate, a symbolic gesture of good faith. There was no real added value of having persons of color in significant leadership roles on campus" (Valverde, 2003, p. 178). Unfortunately, Hoskins (1978) noted the same trend: administrators at white institutions placed Black administrators in newly created positions, which carried the stigma of window dressers or tokens because of the lack of authority and power given in the roles outside of those related to minority affairs. An interesting perspective to consider is the benefit of hiring Black administrators to work exclusively on minority matters. "Black administrators are uniquely positioned to handle the dirty work of the institution such as dealing with differences and diversity at the inevitable price of being considered an 'Uncle Tom"' (Wiley, 2001, p. 127).

Hale (1975) said, "Unfortunately the influence of Blacks in white institutions of higher education is no more than a sprinkling of pepper" (p. 51). Mustaffa (2017) added the following perspective: 
Access did not change the white power structure of higher education institutions, but it did disrupt how white supremacy and racism functioned. Hence, access is not a measure of progress but a marker in mapping both the predictability and malleability of power. (p. 723)

Many Black administrators came into these spaces excited about doing great work while proving themselves within the administrative ranks of the institution. By no fault of their own, Black administrators were unable to control the manner in which they were hired. M. C. and Harris (1978) declared that tokenism is a reality of their high-level position because of the circumstances surrounding their selection. Whether Black administrators were a selection of the white institution (the establishment) or the byproduct of advocacy from the Black community, the administrators must be cognizant of the values they possess that caused their selection and recognize how they are seen by others in relation to Black and white communities. Black administrators cannot control how people see them--as tokens or not within an organization; however, they can focus on letting their service and engagement prove their worth. They have an opportunity to recreate this perspective once they are within these organizations based on the way they decide to operate. 'However, being called a 'token' and behaving like a token are two different things" (Nelms, 1999, p. 55).

\section{Pawn}

One way that Black administrators are setup for failure is through speaking and writing on behalf of the institution in the capacity of their role without having any personal or professional legal protections for those actions. Administrators do not have academic freedom in higher education. Academic freedom gives faculty the right to teach their classes without undue interference from the university (American Associate of University Professors, 1915). In other 
words, what faculty do and say at in the capacity of their role, teaching, is protected. Faculty, students, and the institution are given academic freedom; however, academic freedom does not exist for staff acting in a non-teaching capacity. This distinction was made clear because of two landmark cases: Sweezy v New Hampshire (1957) and Griswold v Connecticut (1965). Sweezyv New Hampshire established the University's four essential freedoms to establish for itself: who teaches, what is taught, how it is taught, and who is taught. Building upon that foundation was Griswold, which linked academic freedom to the express rights of freedom and speech in the specific context of academia. This reality leaves Black administrators completely vulnerable to any and every liability that exists as they execute their primary and veiled job responsibilities.

Being devoid of academic freedom is difficult for Black administrators because they are liable for what they say, even if they are just the voice for senior-level administrators. The literature explored highlights what it means to be tokenized; however, absent are narratives that illustrate Black administrators as puppets to the ventriloquist--the University. A ventriloquist is someone who appears to make his or her voice come from a manipulated puppet. As previously discussed, people who occupy positions without power or authority are often at the will of those who do. Having a position without power can create dissonance for the speaker when the message is not personally recognizable. Jackson (2001) spoke his truth to this phenomenon when he cautioned HWIs to be careful not to ghettoize Black administrators. Black administrators are often called on to provide an expert opinion or intervene in issues that involve some aspect of race and ethnicity. Wiley (2001) offered his truth on being an administrator:

Faced with this harsh reality, there is a concern that the sometimes-coveted role of administrator, which ideally equates to leader, is nothing more but a duplicitous term that really means pawn, or even worse, servant. What other term should be 
used to define an administrator who is hired to function as the mindless operator of a preset agenda? And yes, servant does add an additional element of anxiety to the analysis when the administrator is of color. (p. 126)

During slavery, the master was in charge of the plantation but the overseers supervised the field slaves. Overseers were Black too. They reaped special benefits from the master; however, they were not exempt from the harsh realities of slavery. A slave by any other name is still a slave. Black administrators, if not careful, run the risk of being an overseer in disguise. I am guilty of being used as a pawn in the name of professionalism. I can recall moments when I intervened in situations to keep the peace or to fix it. There were times when I avoided looking in the mirror because I was terrified of who I might see staring back at me. I had been given power without actually being empowered. Black administrators must be empowered to be, become, and belong. The time is now to start thinking about solutions to these problems that would change the landscape of higher education.

\section{Between Two Worlds}

Black people living in America know what it means to live between two worlds (DuBois, 1897; Pinderhughes, 1989). From the moment the first slave ships arrived in Jamestown, there was a clear separation between how Blacks and whites lived. Despite this separate but equal doctrine, Black people have always had to exist in two worlds. This separation existed in our society through the Jim Crow and Civil Rights era. For higher education, desegregation became a reality through the groundbreaking Supreme Court ruling for Brown v. Board of Education (1954). It was during this time that educated Black people began receiving offers for administration positions from HWIs. "At least 95 percent of the first wave of African American 
men to access white universities and colleges were born, educated, and started their education career in a segregated America, both de jure and later de facto" (Valverde, 2003, p. 75). Despite the prerequisite lived experience in a segregated America, Black administrators were not prepared for the harsh realities of being, as my grandmother use to say, "The only chocolate chip in a cup of milk." Jackson (2001) emphasized this expression in the following statement:

PWIs should recognize that for the most part, African Americans are in a dichotomous world: one African American and the other majority white. The vast majority of PWIs still maintain vestiges of the old systems that were designed primarily for white men. There is a different 'face' that many African Americans have learned to wear in these old system environments in order to successfully negotiate them. Although many African Africans have learned to negotiate these types of environments, there can still be feelings of alienation. (p. 106)

Wiley (2001) noted a theory that Black folks are bilingual and this lived experience is rooted out of the slavery. In slavery, Black people learned to communicate with each other in passive and symbolic ways to avoid the messages being understood by the master of the plantation. The Underground Railroad is one example of how this works. By using songs and patterns knitted into blankets, escaped slaves navigated their way to freedom.

Another example of being bilingual is the way Black men express themselves with a nonverbal greeting--often referred to as the head nod. Anyone who self-identifies as a Black person is familiar with this practice. When a Black man sees another Black man in a space with a significant amount of white people, they give each other a subtle head nod when they make eye contact. This nod acknowledges each other's presence while communicating a sense of universality. Gordon (1997) described the art of this exchange like seeing oneself in the mirror. 
In addition, Gordon says white people in these spaces seek to be the mirror for Black people, which can create a mirage of reflection; however, they are not the mirror. The mirror lies in the reflection of your own image. For Black administrators, this form of underground dialogue can be empowering; however, there is a different method of negotiating that is rooted in survival.

People of color often engage in a phenomenon referred to as code switching. Codeswitching for people of color means separating our personal lives from our professional identities. White people have the privilege of being able to be themselves in any setting they occupy. At the core of this perpetual alternation of being are cultural differences between people of color and white people. Glaude (2016) believed that Americans engage in masking as a mechanism to avoid the complex and ugliness of race. White people tend to mask their beliefs on race out of fear being considered a racist. Black people who work and live in predominantly white spaces engage in masking differently. Efforts to mask might mean changing our voice, laughing at things that are not funny, or attempting to change our outward appearance (e.g., hair, clothes, etc.) to blend into the salient culture. Masking is an attempt to appear normal in order to avoid the subject of race altogether. Masking for white people means holding back an opinion whereas masking for Black people means concealing our cultural identities (Glaude, 2016).

Two important perspectives on the dichotomy of existing between two worlds comes from Elaine Pinderhughes, a social psychologist, and W.E.B. DuBois, a renowned sociologist. Pinderhughes (1989) presented a slightly different concept called biculturalism to shed light on this phenomenon. Biculturalism means relating to two worlds without being fully integrated into either one of them. This phenomenon applies mainly to white ethnics who experience this state as a condition of their immigrant status and to people of color. Immigrants are eventually given 
the opportunity to integrate their two worlds. People of color must learn how to navigate this duality without being destroyed by the consistent collusion of two worlds.

DuBois introduces the concept of double consciousness as a symptom of the tension in being caught between these two spaces. DuBois (1897) expressed how he sees double consciousness manifesting itself in the following statement:

It is a peculiar sensation, this double-consciousness, this sense of always looking at one's self through the eyes of others, of measuring one's soul by the tape of a world that looks on in amused contempt and pity. One feels his two-ness--an American, a Negro; two souls, two thoughts, two unreconciled strivings; two warring ideals in one dark body, whose dogged strength alone keeps it from being torn asunder. (p. 194)

This description of double consciousness reminds me of the Native American proverb that my mother taught me that says, "inside of me there are two dogs. One is mean, the other is good, and they fight each other all the time. When asked which one wins, I answer, the one I feed the most."

Many people misinterpret DuBois' concept of double consciousness to mean that the fate Black people is to be trapped between two worlds for the rest of their lives. Like Pinderhughes, DuBois believed that an integration process--psychic liberation--is the remedy for double consciousness. A critical component of DuBois' view of double consciousness, which was often overlooked and misunderstood was clarified by Caldwell and Stewart (2001):

For DuBois the problem of psychic duality emerges principally when individuals develop an uncritical commitment to western values, and in particular overestimate the efficacy of formal education (higher education) before acquiring 
knowledge about and an appreciation of Black culture, that is, alienation from the common experiences of peoples of African descent distorts the process of identity development. (p. 226)

This statement is profound because it boldly declares the solution to avoiding double consciousness is to be grounded in our Black identity. An expression shared by my grandmother said, "It is okay to wear different mask as long as you do not forget your face."

The challenge for most Blacks who profess to be possessed by DuBois' double consciousness is there becomes a tendency to see and experience things from the perspective of whiteness. Allen (1997) highlighted this revelation by saying, "For what DuBois strictly meant by the phrase was the absence of true self-consciousness on the part of Black Americans, the inability to recognize one's Black self other than through the mediated veil of the unacknowledging white gaze" (p. 52). Simply put, Black administrators would not be between two worlds if they truly understood the importance of residing in one world while remaining a visiting stranger in the other world. "A radical scholar cannot occupy the liminal spaces of the academy without accentuating a distinctive voice, one that freely disturbs and subverts the silences and complacencies of the academy" (Dei, 2017, p. 13).

\section{The Underrepresentation of Black Administrators}

The Servicemen's Readjustment Act of 1944, commonly referred to as the GI Bill (United States, 1944), provided funds for veterans of World War II to attend college and participate in other postsecondary education programs. The GI Bill relied on the cooperation of colleges and universities as well as funding from the federal government for students' financial aid (Thelin, 2014). Greater access to higher education peaked the awareness of Black professionals to administrative opportunities at HWIs. Unfortunately, access is only the beginning or simply just 
getting in the door.

Many argued that the root of the underrepresentation of Black administrators might be a pipeline issue among Black students from K-20 (Bichsel \& McChesney, 2017; Harvey, 1999; Mitchell, 2017; Simmons, 2017). Carnevale and Strohl (2013) disclosed the harsh reality that the postsecondary system mimics and magnifies the racial and ethnic inequality in educational preparation it inherits from the K-12 system that ultimately gets projected into the labor market. The pipeline argument is rooted in deficient thinking because it articulates the outcome, less Black men accelerating through college, without acknowledging the broke education system that many Black children have to endure. The conversation about Black men graduating from college to persist through doctoral programs is premature. To consider college as an option, Black adolescent men must complete high school; however, evidence shows that too many are not successful (M. Dumas, 2014; M. J. Dumas \& Nelson, 2016; Simmons, 2017).

A huge contributing factor to this inequity lies within the disparities of the K-12 education system. M. C. Woodard and Harris (1978) noted how racism affects Black students while navigating $\mathrm{K}-12$ :

Racism is reflected in the ratio of Black and white students to Black and white staff members, the makeup of the school boards, publishers of educational materials, and other school-oriented business. Far longer than most Blacks care to remember, the system has programmed Black children to study the history and culture of white people without even casual attention to their own history. And where a revised curriculum exists in a system, including the history and culture of Black people, how much of it is being used in 'all-white' schools? (p. 18)

For Black adolescent men, this system is marred by inadequate resources, deplorable school 
learning conditions, demoralized and underpaid teachers, low test scores and graduation rates, and over referrals to the school disciplinary process that result in the removal of many of them (Williams, 2013).

Numbers reflecting Black students transitioning into college are low. "Although 14.6 percent of the nation's population aged 18 through 24 is Black, only 9.8 percent of full-time, degree seeking undergrads at public colleges and universities are Black” (LaMont Jones, 2018).

Less than half of that $9.8 \%$ represent the number of Black men pursuing degrees at public institutions. In 2016, of the 54,904 doctorate degrees earned, Blacks represented $6.6 \%$ and whites represented $71.5 \%$. Of the 5,153 doctoral degrees earned in education in $2016,14.6 \%$ were earned by Blacks while $67.1 \%$ were earned by whites (The Chronicle of Higher Education, 2018a). Carnevale and Strohl (2013) revealed this statistic in their report entitled "Separate and Unequal."

White students are increasingly concentrated today, relative to population share, in the nation's 468 most well-funded, selective four-year colleges and universities while African American and Hispanic students are more and more concentrated in the 3,250 least well-funded, open-access, two- and four-year colleges. (p. 7) This data suggest that where Black students attend college is important. Compared to the more than 3,250 open-access two- and four-year colleges, the 468 most selective colleges offer many additional resources to ensure student success. These resources include access to a larger volume of digital journals, internships and job opportunities, and more tutoring services available. Outside of physical resources, these selective colleges are leading in higher graduation rates, producing higher lifetime earners, and providing greater access for White students to managerial and professional elites (Carnevale \& Strohl, 2013). Matriculating successfully through thpipeline 
for Black students is difficult because their available higher education system is separate and unequal. Furthermore, the Black students that are present on college campuses are impacted by the lack of Black faculty and administrator presence in their lives (Strayhorn, 2012).

A correlation exists between the presence of Black faculty and administrators and the persistence and success of Black students. Jackson (2001) stated, "The presence or lack of African Americans in the administration of a college or university provides a sense of whether an African-American student will or will not feel welcomed at the institution" (p. 94). Dugas (2002) echoed this sentiment by acknowledging that many Black administrators and faculty remain at these institutions because they recognize that if Black students do not see them, they will lose them. Even though it is not explicitly stated in the literature, my experience suggests the presence of Black faculty and students also helps to make Black administrators feel welcome. "They [Black Administrators] often are the only mentors that Black students have, and the only colleagues Black faculty have whom they feel they can trust" (Wiley, 2001, p. 145).

\section{Summary}

This chapter provided a thorough overview of the relevant literature on Black administrators at HWIs. The guiding frameworks, BlackCrit and marginality and mattering, were described in detail as they are critical lenses in exploring the literature. The historical and present challenges faced by Black administrators at HWIs was outlined as well. Chapter IV explores the research methodology used for this study. 


\section{CHAPTER IV: METHODOLOGY}

The purpose of this qualitative research study was to unmask the ways that senior-level Black administrators process, navigate, and make meaning of their lived experiences and antiblackness at HWIs. In this chapter, the methodological approach and research design are explained.

\section{Research Questions}

This study was guided by the following research questions:

1. How do senior-level Black men who are administrators navigate anti-blackness at HWIs?

2. In a HWI context, what extent does anti-blackness affect Black men's ability to lead?

3. In what ways do Black men administrators use their Blackness to navigate HWIs?

4. How do Black men make sense of their administrative role and responsibilities in an HWI?

5. How do Black men administrators prepare for the opportunities and challenges of being a senior-level administrator at an HWI?

\section{Rationale for Qualitative Research Design}

A qualitative methodology was used to understand how senior-level Black administrators are affected by their lived experiences and anti-blackness within the confines of the world around them. Anti-blackness is pervasive and omnipresent; therefore, it is impossible for Black men in senior-level administration positions in white spaces to avoid it. The power of interpersonal communication provided an unique opportunity to learn about other people by hearing about their experiences directly from them. "The intent of qualitative research is to examine social situations or interactions, with the researcher becoming immersed in the world of others in an 
attempt to achieve a holistic understanding of a phenomenon or experience" (Bloomberg \& Volpe, 2019, p. 42). Black administrators are urged to speak candidly about anti-blackness to unearth the tools needed to deconstruct its adverse implications.

The research paradigm was qualitative and critical. The goal of this study is to transform working relations between Black men and higher education administrators. "Critical theory is a branch of social theory that often attempts to understand conflict and oppression in order to bring about social change" (Winkle-Wagner, Lee-Johnson, \& Gaskew, 2019, p. 5). The critical theory paradigm is also known as an advocacy, liberatory, or participatory framework. More specifically, Glesne (2011, p. 10) said this theory is "positioned in the experiences, values, and interests of a group that has traditionally been oppressed or excluded (women, gays, lesbians, people of color, colonized, etc.)." Critical research provided an avenue to critique, construct, and deconstruct the marginalizing conditions faced by those inhibited within these dynamics.

The goal of this study was to establish another political debate platform and promote discussions to empower people to take action, bring about change in existing social structures and processes, and reconceptualize the entire research process (Bloomberg \& Volpe, 2019). A critical lens for this study allowed me to dismantle oppressive systems that marginalize groups of people, which also aligned with one of the guiding frameworks--marginality and mattering. This study can expose and mediate the anti-blackness ideology by making its existence saliently known, heard, and acknowledged. Furthermore, this study can contribute to existing language previously defined by existing scholars of anti-blackness (Dei, 2017; M. J. Dumas \& Ross, 2016; Grant et al., 2019; Johnson, 2019; Kendi, 2019; King, 2016; Newton, 2017; Parker, 2019; Patterson, 2018; Sharpe, 2016; Vargas, 2018; Wilderson, 2010). 


\section{Critical Ethnography}

The research method was critical ethnography. Critical ethnography derives from the critical social theory; in fact, it is known as critical theory in action (Madison, 2020). Madison (2020) described critical theory as intellectual rebellion and establishes the aims of critical ethnography.

The roots of critical thought spread from a long tradition of intellectual rebellion in which rigorous examination of ideas and discourse constituted political challenge. Social critique, by definition, is radical. It implies an evaluative judgment of meaning and method in research, policy, and human activity. Crtitical thinking implies freedom by recognizing that social existence, including our knowledge of it, is not simply composed of givens imposed on us by powerful and mysterious forces. This recognition leads to the possibility of transcending existing forces. The act of critique implies that by thinking about and acting upon the world, we are able to change both our subjective interpretations and objective conditions. (p. 21)

The intersection between theory and method are essential to understanding critical ethnography. While theory guides the construction of the research design, it is the interpretive or analytical method that directs the completion of fulfilling the research design; henceforth, critical ethnography is the performance of critical theory (Madison, 2020).

One of the goals of critical ethnography is to name and analyze what is intuitively sensed. To achieve this goal, critical ethnographers become immersed in the daily lives of research participants through observation. Fieldwork is a significant aspect to critical ethnography. "The final product is in effect a holistic cultural portrait of the group and incorporates the views of the 
participants (emic) as well as the views of the researcher (etic)" (Bloomberg \& Volpe, 2019, p.

110). "Ethnography is a form of qualitative research focused on discovering and describing the culture of a group of people and learning what it is like to be a member of the group from the perspectives of the members themselves" (Bloomberg \& Volpe, 2019, p. 52). Using critical ethnography empowered the participants to speak their truth to influence individual, cultural, and institutional change. BlackCrit equipped this study with the necessary framework to explore Black experiences only in relation to Blackness itself. This study explored anti-blackness as a root of suffering and Blackness as the necessary solution. This study sought to better understand how Black men navigate anti-blackness in their actions and through the perceptions of their Black identity. G. Anderson (1989) characterized critical ethnographers as people seeking to understand interactions by generating insights to explain events. One of the roles as a critical ethnographer is to study society as it transforms through revealing dominant social constructs to free people from the repression. Navigating as a critical ethnographer required bearing the responsibility to address processes of unfairness or injustice within a particular lived domain-university administration at a HWI (Madison, 2020).

The overall research design was carefully selected to amplify the guiding lenses, BlackCrit and marginality and mattering. Qualitative inquiry, in the form of critical ethnography, allowed the opportunity to capture the stories of the research participants for a deeper understanding of their lived experiences as Black men in senior-level administration at an HWI. Since the HWI's policies and practices posed challenges for Black administrators, critical theory was a gateway into the marginalizing and mattering experiences that leads to systematic changes. With it being an action-oriented method, critical theory strongly supports using the results from this study to educate hiring managers at HWI, train aspiring senior-level Black administrators, 
and inform institutional changes to best support future administrators.

\section{Participants and Recruitment}

After receiving Institutional Review Board approval, I initiated the participant recruitment process. Research participants must have met the entire list of the following criteria: (a) identify as Black or of African descent; (b) identify as a man; (c) currently work at a 4-year HWI in a senior-level position such as president/chancellor, vice president/vice chancellor, associate or assistant vice president/vice chancellor, provost or vice provost, associate or assistant vice provost, dean, and department chair: these administrative leaders are in academic affairs or student affairs; and (d) have 7 years or more of progressive experience in higher education.

The method of snowball sampling was selected for this study. Snowballing gave me access to quality candidates who were willing to participate because of the established connection with a trusted colleague who submitted the nomination. I solicited nominations for eligible participants through my professional networks (see Appendix A). I reached out to various colleagues through the Association of Student Conduct Administrators, NASPA, and the University Council of Educational Administrators for nominations for ideal candidates.

Using the snowball sampling method, I identified 19 prospective participants who met the prescribed criteria for the study. All prospective participants were sent a letter via email inviting them to consider participation in the study (see Appendix B). Eleven administrators agreed to participate and completed participant consent agreements (see Appendix C) that were

collected on the day of their interview. The remaining eight administrators declined to participate in the study for various reasons: schedule misalignment, concerns about identity concealment, or failure to respond to the invitation email. The final number of study participants was 11; 
however, two of the participants did not complete all three required forms and so dropped from the study. As a result, nine participants comprised the final sample size used for this study. Table 1 shows the demographic background of the nine participants.

Table 1

Participants' Demographic Information

\begin{tabular}{lcccc}
\hline \multirow{2}{*}{ Participant } & \multicolumn{2}{c}{ Type } & \multirow{2}{*}{$\begin{array}{c}\text { Reporting unit } \\
\text { affiliation }\end{array}$} \\
\cline { 1 - 1 } Trayvon & Position & Institutional & & Student affairs \\
\cline { 3 - 4 } Fred & I & Public & & Student affairs \\
Eric & I & Private & & Academic affairs \\
George & II & Private & & Academic affairs \\
Medgar & II & Private & & Academic affairs \\
Malik & II & Private & & Student affairs \\
Michael & I & Public & & Academic affairs \\
Ahmaud & II & Public & & Student affairs \\
Martin & I & Private & & Student affairs \\
\hline
\end{tabular}

Note. Type I = president/chancellor, vice president/chancellor, or associate/assistant vice president/chancellor; Type II = provost, associate/assistant provost, dean, or department chair.

\section{Data Collection}

For the purposes of this study, I applied three forms of data collection: in-depth interviews with eligible research participants, interviews with one of their colleagues familiar with their work, and field observations on their respective campuses. I used these data to achieve triangulation. In-depth interviews were used to develop a deeper understanding of the cultural nuances of being a Black administrator at HWIs (Saldaña, 2016). The utilization of field observations was selected because critical ethnography is a field research, which means spending time within the participants' everyday environment strengthened significantly the data collected. 
The participants' actions and experiences influenced the culture at their HWI and the culture at their HWI influenced the participants' actions and experiences: reciprocity of influence. The data collection approach embodied the spirit of critical ethnography because of the richness gained from hearing, seeing, and observing the participants' real-time experiences at their campus.

All participants completed a participant consent form (see Appendices C \& D). The indepth interview (see Appendix E) and field observations took place on the participant's respective campus where they are serving as senior-level administrators. I interviewed each participant one time for 60-90 minutes during my on-campus visits. The in-depth interviews were audio recorded while I took minimal notes to ensure I was focused on the content of the dialogue. Seven days prior to my campus visit with them, each participant was sent an article (see Appendix F) about the resignation of Dr. Jamie R. Riley as Dean of Students from the University of Alabama. I asked them to be prepared to discuss the article during the interview. I used Dr. Riley's resignation because it occurred during the timeframe the interviews were conducted. I anticipated that it would be difficult for the participants to share their experiences thoroughly. This article was strategically selected because its content provided a segue to discuss their perspectives of this incident in relation to their lived experiences at HWIs. Because the article was discussed at the beginning of every interview, it served as a great icebreaker to make the participants comfortable before diving deeply into their experiences. Furthermore, it represented a symbolic lynching that is not only familiar to Black administrators at HWIs, but it illustrated a reality that many of the participants never wished to experience themselves. The inclusion of this article yielded invaluable insights and perspectives while unmasking antiblackness. 
The field observations were conducted for approximately 4-6 hours at each location; I shadowed each participant to see the interactions within the natural elements of the workday. To protect their identities, I informed everyone whom I interacted with that I was shadowing them because of my aspirations of one day becoming a senior-level administrator in higher education and that the purpose of my presence was to learn about their lived experience through observation. This language was critical as it accurately reflected my reason for being there without compromising the integrity of the study or disclosing their participation.

Each research participant was asked to refer me to a colleague who could speak to his experiences as a senior-level administrator at an HWI. These colleagues must have either currently worked with them at their institution or had previously worked with them within the last 5 years. Collegial interviews were conducted in person on the same day as the on-campus visit, if they currently worked with the participant, or interviews were conducted by phone for those referred colleagues who previously worked with them. These interviews lasted 30-45 minutes and focused primarily on their observations and perceptions of their colleague as a Black administrator. Referred colleagues also had to complete a slightly modified version of the participant consent form (see Appendix D), which were collected prior to the start of my interview with them.

\section{Data Analysis}

The data analysis process entailed establishing a method of managing the large volume of data collected in this study. The goal was to reduce the data in both a meaningful way and one consistent with the guiding frameworks. Coding represents the stratification process used to make meaning of the applicable data collected for the purposes of a research study. The data analysis process allowed the opportunity to pinpoint significant patterns and communicate the 
core of what the data revealed in relation to this study (Bloomberg \& Volpe, 2019). To achieve this critical task of bringing the data to life, I used three coding cycle methods to analyze the qualitative data from this study: initial, In Vivo, and focused coding.

Initial coding: As a researcher with a large volume of data collected, it was important to establish a preliminary review of the data to reduce and establish beginning themes. The first cycle of coding was an initial coding. It was important to reflect upon the data prior to embarking in the initial coding process. Initial coding offered a starting point of exploration to determine where the direction the data might lead. Saldaña (2016) described initial coding as "an opportunity for you as a researcher to reflect deeply on the contents and nuances of your data and to begin to take ownership of them" (p. 115). Ultimately, this coding cycle helped to make the data categorization much easier. It provided a baseline to build upon that was essential for the credibility of this study.

In Vivo coding: The second cycle of coding was In Vivo coding. This coding method was selected because it presents [conjured] the actual language used by the participants. The heart of this study was centered on the lived experiences of Black administrators at HWIs. It was necessary to use a coding method that would elevate their perspectives in their words. In Vivo coding has been particularly useful in ethnographies where voices are often marginalized; however, this method of coding deepens the understanding of their worldviews through the utilization of the voice of the participants (Saldaña, 2016). As a researcher, the most powerful moments in the data collection and analyzation processes were hearing the participants use [weaponize] their authentic voices effectively to convey a deeply significant viewpoint. For critical ethnography, this coding cycle was very instrumental in unmasking the anti-black lived experiences of my participants. 
Focused coding: The third and final coding cycle was focused coding. "Focused coding searches for the most frequent or significant codes to develop the most salient categories in the data corpus" (Saldaña, 2016, p. 240). This coding method helped to reconcile all of the major themes and patterns. It was the refinement and definitive process needed to solidify the findings of this study through the lens of the guiding frameworks.

\section{Trustworthiness}

In qualitative research, the subjectivity of the critical ethnographer is important. As Madison (2020) offered the following perspective:

We understand the meaning of an event or circumstance cannot be devoid of the speaker's subjectivity of the narration that brings the event or circumstance into being. What is significant for us is how experiences are expressed and enacted through the speaking subject. An experience or event that we wish to grasp as researchers will always be grasped through the degree of subjectivity encased in the expression of the telling (the participant's subjectivity), as well as the degree of our own subjectivity that is encased in our listening (the researcher's subjectivity). Subjectivity becomes all at once a vessel, lens, and filter of every telling. (p. 47-48)

I recognized that my positionality as a Black administrator at an HWI was both my strongest asset and greatest risk. For this reason, it was important that mechanisms were put in place to ensure any biases were mitigated and not allowed to taint the data collection and analyzation process. The four criteria for trustworthiness in qualitative research are credibility, dependability, confirmability, and transferability (Bloomberg \& Volpe, 2019).

Credibility: One of the factors that led to this study were my concerns about becoming a 
senior-level administrator within the confines of an HWI. I am an outsider. My assumption as an outsider was that the overall quality of life for these administrators can be summed up in one statement--public success, private mess. The financial compensation appeared highly rewarding; however, the time commitment required to be successful within the role seemed overwhelming. I wondered about the toll and taxation of the overall quality of life for Black men in these positions. Furthermore, the reality of operating within an anti-black environment left me wondering what I had to lose if I gained one of these positions. As a researcher, I recognized my biases and took care not to let them taint this study.

"Reflexivity is the process through which researchers seek to acknowledge, examine, and understand how their positionality (i.e., their own social and cultural background, beliefs, and assumptions) can impact the research process" (Bloomberg \& Volpe, 2019, p. 46). For these purposes, I began chronicling my thoughts, assumptions, and questions in my research journal to promote intentional and deep reflection throughout this process and beyond. I also kept a journal for documenting.

I had the interview questions reviewed by my dissertation chairperson and the methodologist on my dissertation committee before my first campus visit. I selected one of my fellow doctoral colleagues, Dr. Jacqueline Hester, who engaged with me in peer debriefing. Finally, I utilized thick description as a means to provide descriptive, specific, and highly detailed accounts of every aspect of my data collection process.

Dependability: Peer examination and audit trailing as methods for ensuring dependability were used in this study. After my data were transcribed, I selected one of my peers to code one of the transcripts from a randomly selected interview. All identifiable information had been removed and pseudonyms were added to protect the identities of my participants. In addition, I 
kept a detailed audit trail to track data collected from the in-depth interviews and the field observations.

Confirmability: Triangulation and active reflecting in my research journal were utilized for confirmability. For the purpose of my study, triangulation specifically referred to the multiple methods of data collection. This practice provided multiple ways to access information given. It also created an opportunity to explore new dimensions where people behave inconsistently (Glesne, 2011). Furthermore, journaling continued to be a practice to reflect on my own experience as a researcher and the overall process.

Transferability: Thick description and detailed information are important techniques for transferability used for this study. These techniques required detailed information that provided descriptive, specific, and highly detailed accounts of every aspect of my data collection process. The richer the detail of the data collected, the more opportunities it created for individuals who will read this study to understand how the outcome was achieved. It also leaves room for them to draw their own conclusions based on the study.

\section{Potential Risks}

Risks associated with this study were minimal aside for some general discomfort: Some responses from the participants invoked strong emotions. To mitigate these risks, participants had the right to stop participation in the research at any time or at any point in the process without any repercussions. The interview questions were not be shared with participants in advance; however, I sent an email at least five business days prior to our scheduled time together to give participants time to reflect upon identified themes. This reduced the risk of participant forgetfulness. To mitigate the risk of a confidentiality breach, only the principal investigator, Dr. Pamela Hoff, and I had password-protected access to the data. All audio recordings, transcribed 
interviews, and notes were stored on a university issued, password-protected computer. Direct quotes from participants were used in this study; however, all identifying information was stripped from the responses and pseudonyms were used.

\section{Ethical Issues and Reciprocity}

The purpose of my study was to unmask some of the successes and harms that come along with being a Black administrator at an HWI. As a researcher, it was important for this study not to create any unnecessary harm for my study participants. This study was voluntary, and participants had the option to withdraw from the study at any time during the process. To avoid any potential risk of identity exposure for the study participants (because of the few Black administrators in higher education); safeguards (e.g., pseudonyms, secured data, etc. ) were put in place to prevent that from happening.

To protect the privacy of my participants, I collected anonymous information and ensured the information collected was confidential. "Confidentiality is an agreement with the researcher about what can be done with the information obtained about a research participate" (Bloomberg \& Volpe, 2019, p. 201). This study did not include any identifiable information of participants. All participants were initially asked to create a pseudonym that was used for the data collection phase of this entire study. After the data were collected, I randomly selected new pseudonyms to add an additional layer of privacy for the participants' identities. Any identifying information with even a small trace of information was cloaked or omitted. The campus site will be protected and referred to by pseudonym. No information will be offered about the location of the institution. I took an additional step and did not post on any of my social media platforms any locations or that I was conducting interviews and observations to minimize the possibility of unintentionally disclosing this information. To further protect their identities, I informed 
everyone whom I interacted with that I was shadowing the participants because of my aspirations of one day becoming a senior-level administrator in higher education; therefore, the purpose of my presence was to learn about their lived experience through observation. This language was critical as it accurately reflected my reason for being there without disclosing their participation in the study. All audio-recorded interviews were protected and kept in a secure location that only I had access.

In terms of reciprocity, I provided a unique opportunity for my research participants to reflect on their lived experiences in higher education in a meaningful way. By listening, I affirmed them while increasing their sense of mattering. Furthermore, the participants were given a platform to contribute to the leading voices for change as it relates to Black administrators at HWIs. Throughout the process, I conveyed to each participant how their stories will be used after the study is completed. I plan to publish articles and present at conferences using their stories to inspire future generations of senior-level Black administrators. Finally, I sent each of my participants a thank you card, via U.S. mail, for their participation.

\section{Summary}

This chapter described the methodology utilized for this qualitative study. The research design was outlined in detail, which included the research questions, researcher positionality, data collection, and data analysis. I described the mechanisms that were used to ensure trustworthiness for this study. I discussed the ethical considerations and confidentiality utilized to protect the identities of participants. In the next chapter, Chapter V, I reported the outcome of the study and the themes derived from the data. 


\section{CHAPTER V: RESULTS}

“But you can't heal what you never reveal” Jay Z (Carter, Parsons, Woolfson, \& Wilson, 2017)

The purpose of this study was to unmask the ways that senior-level Black men who are administrators process, navigate, and make meaning of their lived experiences and anti-blackness at HWIs. The nine participants joined in every phase of the prescribed research design and triangulation was achieved. From the data analysis process, through the utilization of initial coding, In Vivo, and focused coding, arose two common themes and six sub-themes: three subthemes for each common theme. The two common themes identified were anti-blackness and Blackness. These common themes aligned with the literature review and guiding frameworks for this study.

Out of respect and honor for the participants' lived experiences, their actual words were taken verbatim from the transcribed, in-depth interviews. It was vital to represent their thoughts and perspectives precisely to preserve the integrity of this study. The referred colleagues' transcribed interviews as well as the recorded, field-observation notes were also considered in the construction of the study results. The participants also identified specific recommendations for aspiring Black administrators to consider on their respective paths to leadership, which are listed at the conclusion of Chapter VI. This study was guided by the following research questions:

1. How do senior-level Black men who are administrators navigate anti-blackness at HWIs?

2. In an HWI context, what extent does anti-blackness affect Black men's ability to lead?

3. In what ways do Black men administrators use their Blackness to navigate HWIs?

4. How do Black men make sense of their administrative role and responsibilities in an 
HWI?

5. How do Black men administrators prepare for the opportunities and challenges of being a senior-level administrator at an HWI?

\section{A Village of Nine Senior-Level Black Men: The Participants}

The nine participants in this study are senior-level Black administrators at HWIs. Each participant volunteered to be a part of this study and believed that transforming the Black administrator experience at HWIs required candid reflections. According to the National Center for Education Statistics, 2017), Black men represented 21,602 out of 256,267 or $8.4 \%$ of university administrators in the Fall 2016. Participant demographics were provided in Table 1; however, to avoid a breach in confidentiality, minimal information was divulged. Protecting the identity of the participants was very important because all the participants articulated that they were not safe in higher education. Notwithstanding, individually and collectively, they expounded what they envisioned to be the short- and long-term implications of unmasking their experiences for the greater good of the profession. More importantly, they championed the opportunity to disrupt anti-blackness by giving voice to the realities of their lived experiences. Therefore, to truly appreciate the scope of what they shared in this study, one must know them. I described them based on the field observations, what they shared in the interviews, what I experienced from the campus visits, and from the information shared in the interviews from their referred colleagues.

The participants selected pseudonyms for themselves during the data collection phase. Those pseudonyms were only shared with the referred colleagues for interview purposes. To eliminate the possibility of tracing statements made by the participants, I assigned each participant another pseudonym for the purposes of discussing the results and implications. Each 
pseudonym was selected based on the identity of real Black men who have all died at the hands of violence against the Black body: Trayvon Martin; Fred Hampton; Eric Garner; George Floyd; Medgar Evans; El-Hajj Malik El-Shabazz; Michael Brown; Ahmaud Arbery; and Dr. Martin Luther King, Jr. Given the purpose of this study, these names were selected in symbolic tribute to the lives and spirits of their Black lives.

\section{Trayvon}

Trayvon has been in higher education for over 15 years. He is a husband and father to four daughters. His demeanor is calm, yet powerful. He resembles the actor, Steve Harvey. He stands at about 6'0" and dressed-to-impress from head to toe. His office bears no awards, no accolades, or degrees hanging on the walls. There are no pictures of his family, friends, or anyone for that matter. Everything is color-coded and categorized neatly. Not even a pen appeared to be out of place. Trayvon was highly organized and punctual. He arrived at meetings at least 10 minutes before they started. Every meeting he attended was related to student matters; however, student interaction was minimal.

In my observation of him, he spent every moment between meetings either responding to emails or gazing in deep thought out of the window that showcased the entire campus. He takes his work very seriously. As he engaged with others, he greeted everyone with a smile and always took a moment to joke with them. In meetings, he was laser sharp--always seeming to be one step ahead of everyone in the room. He knows it, but he is careful not to allow other people to know this about him. For every challenge presented, he offered a solution. His referred colleague expressed a deep admiration for his deep commitment to his work, his campus community, and his fortitude in the face of adversity. 


\section{Fred}

Fred has been in higher education for over 20 years. He is a husband and father of three daughters. He resembles the late professional basketball player, Kobe Bryant. His presence is larger-than-life, and it matches his physical 6' 5" stature. He is very outspoken and unafraid of difficult conversations; however, he is extremely thoughtful in his delivery. Fred's office had degrees posted on the walls and there were books everywhere. When I inquired about the books, he began to glow as he expressed his critiques and excitements about various books. When it came to discussing issues about Blackness, he reminded me of Fred Hampton. Deeply passionate and knowledgeable, you could not help but feel every word he said.

The colleague who referred Fred shared that he has lunch with students in one of the cafeterias every workday. He does not schedule them in advance; he shows up and identifies a table of students and joins them. During my campus visit with him, we had lunch with a group of students, and he had the group laughing the entire time. If ever he wanted to consider a career outside of higher education, comedy might be his second calling. After lunch, he took me on a tour of the campus. He loves being outdoors and greeted everyone as they passed. In between meetings, Fred checked emails while maintaining a consistent conversation with me.

\section{Eric}

Eric has been in higher education for over 10 years. Both he and his wife are higher education administrators at different institutions. He resembles the actor, Cedric the Entertainer. He worked hard to attain senior-level leadership sooner than most. Eric looks young and has been mistaken for a student twice while we navigated his campus. He was full of energy outside of meetings and his office but seemed anxious with every interaction or new email alerts. Eric visited three Black colleagues on various parts of campus throughout the day. The conversations 
with his Black colleagues were relaxed and informal. They told a lot of jokes while managing to interject some business from time to time.

Eric's office had his degrees posted and nothing else on the walls. He listened to rap music while responding to emails but kept the volume low enough for it not to disturb his secretary. When he was deep in thought, I would toss around his stress ball as if it were a baseball. His calendar was jam packed, but he still made time to make sure I was doing well. He spoke about his family quite often. He mentioned that he missed them and did not know when he would get the chance to visit again. His colleague who referred him highlighted how invaluable Eric was to the campus community.

\section{George}

George has been in higher education for over 20 years. He is a husband and father of one daughter. He resembles the professional golfer, Tiger Woods. He credits his being a Black administrator to his mentor from his undergraduate institution. He knows firsthand what it is like to have and not have resources as a college student. He created signature access and success programs at every institution he has worked. Most of George's interactions I observed were with the students.

George is a strategic thinker with a commanding presence. Throughout the course of the interview day, he selected physical locations away from his office to protect his confidentiality. With every step we took on campus, someone stopped to talk to him about something. He maintained a very serious demeanor; I could never quite know what he was thinking. He was excited to participate in the study because he thought these stories needed to be told. His colleague who referred him noted how George was a strong advocate for anyone in the community, but he is no good to anyone when he is hungry. 


\section{Medgar}

Medgar has been in higher education for over 25 years. He is a husband and father of two daughters. He resembles the actor, Will Smith. Medgar is methodical and pragmatic. He seemed to experience the world in patterns or by a rhythm based on his thoroughly articulated perspectives throughout the day. Though he works at an HWI campus, all his student workers and staff in the office are Black. All the posters in the office suite featured predominantly Black students. His office resembled a library with a plethora of books and awards throughout it. He conducted most of his meetings in the suite conference room; rarely did people meet in his office. He has a strong affinity for his hometown as sports memorabilia was strategically located. Medgar spoke with keen precision that made every word sound like poetry. In meetings, Medgar was solution-focused and kept every meeting flowing on time. He tried telling jokes every now and then, but they did not land well. Everyone still laughed; however, not at him but with him because of his reactions to his jokes--priceless! His colleague who referred him discussed how calm under pressure he was and how he never let conflict get in the way of progress.

\section{Malik}

Malik has been in higher education for more than 15 years. He is a husband and father of three daughters. He resembles the actor Blair Underwood. Malik is the kind of person you know is in the room before he announces himself. When he arrived at meetings, the noise in the room silenced immediately. He did not do a lot of the talking; he simply observed. In observing him, I could tell he was taking notes in his head. He allowed others to discuss various topics until it was time for him to solidify the final decisions. He did not bother to take lunch or have anything to drink the entire day. 
His office desk was filled with folders and papers. It appeared disorganized, but he clearly had everything in place such that only he understood. When he spoke, his voice carried. Even when he was talking low, I was sure other people could hear us. Everything he said sounded like he was about to sell you something. In between meetings, I observed him responding to emails and phone calls. His day had a distinct rhythm that never stopped flowing. His colleague who referred him shared that Malik is often labeled as unapproachable and it was speculated that the cause was related to his identity as a Black man.

\section{Michael}

Michael has been in higher education for over 20 years. He is divorced with two sons and two daughters. He resembles the singer Smokey Robinson. Michael was cool. Everything sounded chill. He did not seem to sweat the small stuff. Everything that was presented to him as a problem was immediately identified with multiple solutions. His office was decorated with awards, degrees, and pictures of mountains. He shared that he enjoyed traveling to various places around the world to hike mountains. Pictures of his children were displayed in various places around the office. He kept a jar of candy on his desk for guest, but he could never resist getting chocolate for himself as he offered to others.

Michael was very approachable and relatable. He had a way of making one feel like you have known him for lifetime. In between meetings, he wanted to talk about any and everything. He responded to emails as he needed. A student showed up without an appointment and he had his secretary rearrange his entire schedule to meet with them. He talked a lot about the Black colleagues in his life who are like family to him. Michael definitely had a strong presence and he purposely used it to get things done that he viewed as game changers for his campus. The colleague who referred him talked about how much Michael inspired everyone to be true to 
themselves while accomplishing the work. 


\section{Ahmaud}

Ahmaud has been in higher education for over 15 years. He is married with one daughter. He resembles the former basketball player Michael Jordan. Ahmaud was casket sharp — his style of dress was impressive. He projected strong nonverbal affirmations in meetings. It was important to him that the people in the room knew he was listening. Every word was carefully articulated, particularly when his response was not going to be what the other people wanted to hear. In between meetings, silence filled the room except for the sound of his typing as he responded back to emails. The office had on display his degrees and one piece of art that his wife made for him. It was meticulous.

I observed Ahmaud in a meeting where he was level-headed, decisive, and collaborative. He challenged people to consider best practices for recommendations and the feasibility of implementing something based on this campus culture. The colleague who referred him described never seeing him lose his cool and viewed him as being consistent. Ahmaud was celebrated by his colleague for writing some of the most diplomatic emails. This colleague also acknowledged that Ahmaud has to fight the stigma of being seen as an angry Black man, but he does it well through his values and professionalism.

\section{Martin}

Martin has been in higher education for over 20 years. He is not married with two daughters. He resembles the actor and comedian, Mike Epps. Martin is a full character. All of his facial expressions are animated. He cannot hide what he is thinking or feeling because his facial expressions give it away. He is a straight shooter, but I wondered if it was by choice or because his face kept no secrets. Walking around campus with him was like being with a celebrity. Faculty, staff, and students crowded around him and he loved it. At the same time, Martin was 
about his business when it came time to conduct business. His office was filled with university specific memorabilia. No degrees were on the wall; however, awards and certificates received from that institution were displayed.

Martin cared deeply about students and cited the inspiration for him pursuing higher education administration was racial discrimination. In graduate school, he was falsely accused of committing a university violation. It almost costs him his education. He felt unheard and disenfranchised by the process, so he decided to do something about it. He was victorious in his case, but the negative feelings continue to linger. Martin is the kind of person that can tell the unpleasant truth to someone with the biggest smile on his face. He leads with his heart and it is felt immediately. The colleague who referred him discussed how Martin's work ethic and positive energy served as an inspiration for others.

\section{Theme 1: Anti-blackness}

Anti-blackness was one of the overarching themes that emerged from the data. None of the participants referenced the term anti-blackness in relation to their lived experiences, which was expected given the ubiquity of the concept. The sub-themes developed from the data were sundown institutions, personal sacrifices, and work twice as hard. Every participant described anti-blackness in their experiences without using the specific language, which was anticipated prior to initiating this study. The intentional uses of marginality and mattering created a framework to solicit language that reflected their lived experiences. As a critical ethnographer, the strength of this study lies within the unearthing and exposure of this phenomenon known as anti-blackness to develop new strategies to support Black administrators.

\section{Sundown Institutions}

A-N-N-A. A town geographically located in southern Illinois, 20 miles away from 
Southern Illinois University Carbondale. This town represents thousands of small communities in the 21 st century that remain populated with all whites. Historically, A-N-N-A was known to mean "Ain't No Niggers Allowed" and it represented one of the many small town American cities known as sundown towns (Jaffe, 2019). The term sundown town signifies places that barred Black people from town after dark by way of policy, violence, or both; the marker for these towns was a highway sign that stated 'Nigger, don't let the sun go down on you' (Loewen, 2018). Although Anna, IL, and many sundown towns like it no longer have physical signs posted on the highway, there is still a chilling perception among Black people to avoid places like this one after dark. In fact, today, Anna's population is $96 \%$ white residents (Jaffe, 2019). Sundown towns epitomize the spirit of the intentional use of HWI for this study. What the participants of this study revealed was the existence of what I would like to characterize as sundown institutions.

Dr. Jamie R. Riley was appointed as the Associate Vice President and Dean of Students at the University of Alabama in February 2019. He was noted as the first Black person to serve in this role in the institution's entire history. The University of Alabama was founded in 1820 and serves as the flagship institution in the state of Alabama. On September 5, 2019, an article was published announcing his abrupt resignation from the position after only 7 months (Bolling, Brewer, \& Griesbach, 2019). According to the article, past tweets were uncovered where Dr. Riley expressed his views about the impact of systemic racism in America. In one of his tweets, he referenced the American flag and policing being symbols of this racism (Bolling et al., 2019). The timing of Dr. Riley's departure from the University of Alabama came as I was finalizing my interview questions for this study. I decided to include the article announcing his resignation for participants of this study to read, and I developed a series of questions for them to answer during 
the in-depth interview (See Appendix E).

After reading the article, all the participants stated they were not surprised about Dr. Riley's departure from the University, and $89 \%$ (8 of 9) of the participants spoke to the unsettling reality that HWIs are still not safe environments for Black administrators. Even though the institutions may not be located in sundown towns, these sundown institutions projected the same atmosphere. Fred very candidly exclaimed the following:

It's a shame because what it says to me is that this is not a safe environment--this environment meaning higher education--for black men specifically in this case to speak about what they believe and their lived experiences in this country. That's difficult for me. There are a lot of places that might be interesting to work at as an institution, but because of their geography and their history, I think what happened with Jamie is going to be a statement to many of us that says stay where you feel like you belong, if you're going to be political about race issues, at least. I believe in this current climate those places, there are more of those places than we probably previously believed, or that many people previously believed. So, yeah, I think it'll limit us. I think it'll limit people moving around. I think it'll limit people's ability to rise up, those brothers that are coming up the ranks. The flip side is that it also might make people shut up and be afraid to speak up for fear of not being able to advance your career and your family's needs.

Dr. Riley's resignation announcement appeared to send a series of messages to Black administrators. His highly public resignation, which none of the participants were surprised by, played into a symbolic lynching trope (Ore, 2019) that has been historically designed to keep Black people in their place. Fred expounded by saying, 
I also think it's a statement. The way that he was released so quickly is a statement. In this country, you should not . . . especially from the Black community, it is forbidden to critique the oppressor. Right? To critique the oppressor is anti-patriotic. I can't imagine living in Tuscaloosa, Alabama, even in 2019 and being faced with that.

To understand the haunting effects of the format of a lynching, Litwack (2004) considered the following description:

This one became a public spectacle. As in most lynchings, the guilt of the victim had not been proven in a court of law. As in most lynchings, no member of the crowd wore a mask, nor did anyone attempt to conceal the names of the perpetuators; indeed, newspaper reporters noted the active participation of some of the region's most prominent citizens. And as in most lynchings, the white press and public expressed its solidarity in the name of white supremacy and ignored any information that contradicted the people's verdict. (p. 124)

The symbolic lynchings of Black administrators are headline news within publications where readers of the higher education community are invited to witness these removals of Black administrators.

In June 2019, Dr. Jack Thomas, a Black administrator, resigned from Western Illinois University in Macomb, Illinois, after months of pressure from upset faculty and community members (Rhodes, 2019). For 2 years, this president had to face the arduous task of operating without a state budget allocation. President Thomas had to make extremely tough decisions to survive. Under Thomas' tenure, student enrollment declined, three rounds of layoffs resulted in 100 people losing their jobs, residence halls were demolished, and academic majors were shut 
down (Stripling, 2019). Despite the significant impact the state budget had on the institution, people blamed Thomas for all of it.

Being a public figure, especially during times of financial challenges, creates a fishbowl effect or close scrutiny and Black administrators are not immune (Thomas, 2015). Proceeding the announcement of Dr. Thomas' departure, yard signs and marquee signs publicly displayed the statement "Fire Jack" (Stripling, 2019). The campaign to remove Dr. Jack Thomas worked. These signs projected an age-old, anti-black message--Jack, do not let the sun go down on you.

Trayvon shared how he believed these public accounts of the shortcomings of Black administrators are part of what makes working at HWIs difficult. Trayvon indicated, I think people use them as a forum to say, 'Look, they're not as great as we think they are or special.' I think it almost serves as like a dog whistle. I think it serves to kind of ... maybe check you before you get to that level, to know that moving in that direction can cost you your job. And I think that you have to begin to ask yourself, what's worth it?

George was visibly upset when discussing Dr. Riley's resignation. He sat, leaned back, in his office chair and he continuously rocked in his seat. George conveyed the following:

The history of Black men in this country, those that dare to challenge the system, those that dare to speak against the system, those that dare just speak truth to power--they are made examples of and usually it's a negative outcome with individuals in some capacity or other.

In my interview with Eric, not only was he not surprised but seeing what happened to Dr. Riley forced him to re-evaluate his own social media accounts. Eric said,

It made me really question, 'Am I safe?' I was like, 'Oh, shit. We [Eric \& his 
wife] better start cleaning up our social media right away.' I literally went back and looked at some of my old things .... It just resonated well with me in that it made me feel not as safe as I thought I was in higher education.

During my time with Medgar, he spent the most time of the participants breaking down what Dr. Riley's departure meant for Black administrators. He wanted to be very clear that he believed the only two classes of people on campus that truly had freedom of speech without consequence were faculty and students. It was in this moment that Medgar introduced the concept of Black administrators being renters within the confines of HWIs. Medgar stated the following: You're a renter. As a renter, you have certain rights and privileges, but you don't have the same ones as the people who own it, and you've got to figure out a way to leverage your rights and privileges in the context of renting to optimize what you can do for you, your family, and your community. I hear people say they love this university, or they love that college, and I can understand that. I think that's really positive. But what I always tell people is they [the university or college] can't love you back, and you know, once you understand that, the whole renterowner dynamic comes into play.

What Medgar is speaking to is this invisible contract that states that the policies, practices, and rules as written only apply to white people and cannot be utilized by non-white people (Mills, 1997; Serwer, 2020). Furthermore, seemingly unwritten rules exist for Black administrators at HWIs (Hester, 2020). Although Medgar acknowledged that his renter analogy might not have been the best way to characterize his experiences, it sets a significant framework that Black administrators are still "symbolically" not allowed after dark within many HWIs. Trayvon contributed to this notion of the renter analogy when he asserted the following: 
I don't think it's a hospitable environment. I think you are already being brought to a table that not only was not designed for you, but more importantly was designed against you on purpose. Your being there is an oxymoron. People spend most of their time trying to figure out how did you get here? What school did you graduate from? So, I just don't think it's hospitable.

Martin affirmed this statement in his own expression of the following:

That whites are the gatekeepers in so many ways to opportunity, it's never been a kind country for black people.

In March 2020, Dr. Riley broke his silence and published an article that declared Student Affairs was not safe for Black people (Riley, 2020). Dr. Riley avowed that he was walking away from the profession because he mistakenly believed he was truly safe as a Black man in higher education. He declared that he wanted to go to a professional space where he could be free to speak candidly about his lived experiences. There are consequences for Black people who speak out against anti-blackness. In the 10 years Malik has worked at his current institution, he has been reported through the grievance department over 100 times. Though every decision had been rendered in his favor, Malik offered the following insight with respect with Dr. Riley's resignation:

His interpretation of what he was doing is what it is; but given where you work, I think he was on a short leash anyway, given where he was working, not knowing anything about the institution. A lot of white folks, when they get in trouble like that, they might get like laterally moved somewhere else, and they land on their feet. But I think for most people of color in white institutions, they push the eject button; you don't have like a parachute and a place to land. So, my initial reaction 
was, and this may sound cruel given the context of Alabama ... anybody that goes there ought to know better! That goes back to what I was telling you about things to expect from the institution; if you expect too much from them, then you can harm yourself because folks will let you down.

Black men live in a perpetual state of conscious and unconscious fear of being killed or dehumanized at any moment (Curry, 2017). Previous research spoke to the deeply engrained fears of Black men in our society (Curry, 2017; Glaude, 2016; Kendi, 2016); however, this research failed to reflect on the ways this fear has become internalized among Black men. Michael provided this perspective to consider:

Another thing too, people don't realize this, and I've shared this, but I can't get any of my white colleagues to understand this. Every time I see a Black man get shot on TV, even though I don't know him, I feel like he a relative. It affects me, like there's a lot of stress and mental health issues with Black men when we see certain images on TV. It hurts us.

Fred shared a powerful insight into the depth of the fears of Black men that exist in this country. Silence filled the room during the interview in the moments he proceeded to share this story. It was difficult for him to express, but he needed to verbally express it. Fred disclosed the following:

I can say that when my wife was pregnant the second time around, I had already had a little girl who was almost four, and everyone who asked me, it was like, 'Don't you hope for a little boy?' I told them every day, I was like, 'I pray I don't have a little boy.' I was like, 'I have no desire to have the fear of raising a young Black boy in this environment. He becomes a target, right?' I got to deal with the 
issues of raising young, Black women who is probably the most ill-treated group of people in this country, but at least they're not a threat to the police, per se. I had to balance the privilege that I recognize that I bring to the table, having been highly educated.

I had to base my hopes about the gender of my second child on the fact that I believe that my young girls will be able to overcome the oppression that Black women deal with faster than a young Black boy can overcome the oppressive state of being a target ... because those targets don't care about socioeconomic status. Right? They put one on your back regardless. Right? They will put a gun in your face regardless of how much money your parents make, how much education they have, or what schools you went to. They don't care. So, I figured I can mitigate the oppressive ways of the world for my little girls. It's harder to do so with a little boy. Right? That's a major impact for me. My youngest daughter's almost three, and that's the first time I told that story without crying. It's not that I'm not happy I have a little girl. I love my baby. Right? I am happy to have them, but to pray to not have a little boy, if that's not an impact that this country and the racism that lives in it has on a person, I don't know what else could've caused that besides that racism. Yeah, it impacts me on a daily basis.

The role of a senior-level administrator comes with its challenges, but those challenges are magnified once the element of anti-blackness is incorporated. The effects of the fears that fuel sundown institutions have real consequences for the Black administrations who must persist through them on an everyday basis. Sundown towns are still active, but they do not post signs 
anymore. Based on the participants' experiences, there are sundown institutions and they are not safe places for Black administrators. There are some institutions that allow more flexibility for Black administrators to exist. Part of what the participants relayed for aspiring Black administrators to consider is to do the necessary due diligence to determine if an opportunity is mutually beneficial for all parties. Black administrators should beware of sundown institutions in higher education.

\section{Personal Sacrifices}

One of the hardest moments during the participant interviews was when we began discussing the personal sacrifices of Black administrators. Approximately $78 \%$ ( 7 of 9) of the participants spoke candidly about this matter and it required vulnerability. Without being warned in advance, some of the participants had already given this topic prior consideration while others wrestled with the possibilities during the interviews. What they described are things they have lost or exchanged on their paths to senior-level administration at HWIs; and more importantly, the ways they were picked to pieces. Picked to pieces (Hoff, 2020) characterizes a gradual change in one's holistic self, being, or uniqueness. These reflections offered a valuable insight of the personal sacrifices required to be Black administrators, which had not been represented in previous research. Medgar shared the following:

I watched many of my colleagues really sacrifice their families to ascend, and I will tell you that, in fact, my person who hired me here was the leader of this organization. I asked him this very question about how he got to this role and what did he sacrifice. He told me it was his family, and the time with them, and the like. 
From the time I was an assistant professor, when they first started implementing family leave policies, I was the first person in my institution, in my department, who was a male to take the leave. Heretofore, it had always been women taking leaves: largely just because physiologically they had to, but when they opened it up more broadly, I took it. Then, I had a senior colleague tell me that I would never have a good career, and that I would never be a national figure in our field because I wasn't willing to sacrifice this time. I told him, I was like, 'If you want to put your kids on the altar, that's on you, but I'm a renter, dude. This is my family.' You know, that's why that philosophy has always worked for me, because I took the time when my son was born, and I enjoyed the time with him. I did the same thing when my daughter was born. I'm just like, 'Peace be unto you for this semester.' And you know, when I was a chair of the department, I mean, sure, I was at all of the [work] events, but I didn't miss any of their [my children's] events either.

For Medgar, the sacrifice of family was not an option mainly because of his understanding of his role as a renter within the HWIs that employed him. This critical awareness gave him a lens to evaluate his steps. Unfortunately, many of the other participants in this study disclosed their greatest sacrifice was their family. Trayvon stated the following:

There are definitely sacrifices. I think they've looked differently. I think in the very beginning of my career I sacrificed my marriage and my health. I was burning the candle at both ends, and I wouldn't stop to take breaks the way I should. And when you burn the candle at both ends to focus on your career, it leaves very little room to focus on your marriage. So, I stopped that. I didn't quite 
know how to fix that. I tried to slow down and my marriage kind of improved. So, that has been a sacrifice to love and lose those relationships at different points--be able to get it back, then lose it again. And now I got it. And now at this stage, I will never let it go regardless of what. But sometimes that comes with just being older. You really know what you're fighting and playing for. Now that I know and because of that shift, I've tried to make sure that my daughters and my wife know individually and collectively that they are my priority.

Trayvon was honest in his reflections about almost losing his family to his career. As time progressed, he decided that he had to shift his priorities to keep his family intact. Ahmaud shared the delicate balance between time and relationships in this statement:

I think certainly I've sacrificed some relationships at various points in my career in pursuit of advancement. There are many relationships that I neglected or entirely let go of. And it wasn't always ... it was rarely an intentional process. I just tell myself I don't have time to hang out with this person or to catch up with that person. The further you ascend, the further removed you become from your origins. Right?

I would say another real price that I think I paid or sacrificed is when it comes to family time. This role, this position is all encompassing. It is not nine to five. I don't have the luxury of just saying, 'Okay, it's five o'clock, I'm leaving the office now.' I often take this work home with me. The demands of the job often require me to forgo other activities: costing time with my family--activities with my kids. So, I think that's another price that one pays to pursue academic leadership. And again, no one ever tells you that you are expected to do X, Y, and 
Z; but, there's simply not enough time in the day at work to get things done or get the things that are expected of you done.

The reality of the taxation on Black administrators stretches into the scarcity of time, as Ahmaud clearly articulated. Martin expounded on this concept when he discussed managing relationships:

Health, sanity, personal relationships. Not that I've done anything wrong to anybody, but personal relationships take work. They take time and you show me where you put your time, I show you where you value certain things, and so there are relationships that I value to the hill that I chose to put time in. I mean, I used to be a kind of person that was ... and I had hundreds of people that I was speaking to like, over the course of a month, whether it be social media or phone or email and those kinds of things like that. I'm down to probably about 10 to 13 people that I speak to regularly.

In my interview with Eric, he acknowledged that he had only begun to experience personal sacrifices in relation to family. He comes from a close-knit family and extended family who celebrate every precious moment together. Moving around for career advancement opportunities has caused him to miss everything from his grandfather's 77 th birthday celebration to his niece's first words. He was visibly shaken and holding back tears as he talked about it. What was striking came in the following statement as Eric continued to process his emotions on this subject:

What I'm seeing ... what may happen when I do have a family of my own is, I'll have to sacrifice being present for many of the areas of their life. Going back to my mentors, a common theme that I've seen with them with families is, 'Wow, you're here at a late-night program?' 'Yeah, my son has a soccer game,' or, 'He's 
playing basketball. Can't be there. I got to do this tonight.' I want to be a good father to my [future] son because I didn't have a good father in my life. So, I often worry if my career will take precedence.

Eric was already wrestling with the realization that what he observed among his mentors about their approach to family may one day become his reality. Based on the reflections of many of the participants in this study, it could very well become his future lived experience. Michael experienced what it meant to choose his family over his profession; however, even this choice came with an immediate cost. Michael shared his experience:

Yeah so, a lot of the sacrifices I've made have been around my family. And what I mean by that is, I could have moved up like that. I could be a president right now. But because I prioritized my kids and because I didn't want to move them every two years, there you go. Those are the sacrifices that I've made. As far as professionally, I haven't made any sacrifices professionally. They've all been personal sacrifices that have affected me professionally.

While Michael expressed no regrets about his decisions because he still made it to senior-level administration, it is an important lesson for many aspiring Black administrators. The higher one climbs, the potential for personal sacrifices are real.

Malik offered a perspective on what it meant to remain true to himself even at the expense of career advancement. Malik asserted the following:

I think vertical opportunities, when you speak truth to power, make people uncomfortable. You come across as not being a team player, and so a promotion comes hard, because you don't sustain, or you don't represent the hedge of money that existed before you got here. That's the one thing I can think of. Other things 
in terms of my identity and who I am, I think they're very much intact. But just vertical opportunities, that's the one thing I would say.

As the interviewed with Malik progressed, he offered the following insight that illustrated the reality of his ambitions relative to prospects of future personal sacrifices:

My authenticity doesn't compel me to sacrifice who I am ... but I'm consciously aware that if I want to go vertical, I'm going to have to do that [make some personal sacrifices] at some point. But I'm not there yet.

Malik acknowledged that he understood that personal sacrifices were inevitable, which presented one of the toughest components of the Black administrator's lived experience. Personal sacrifices are not an option; however, every Black administrator had to determine what he looked like for each of them. Trayvon went even deeper to describe this notion of muting his colors.

Anytime that I'm adding additional filters just lets me know that I am probably moving further away from me being my authentic self. And it's exhausting. I call it muting my colors. And so, for a little bit at this place, I had to mute my colors. I couldn't really show them how smart I was or what I felt initially. And I think the con of that is because sometimes I'm hiding--I forget myself.

Trayvon revealed the complexity of being a Black administrator in an anti-black environment-the risk of losing oneself while navigating between two worlds (DuBois, 1897; Pinderhughes, 1989). Anti-blackness constructed these environments to suppress and eliminate Blackness. Oftentimes, the expression "play the game" has been utilized as an analogy to describe this notion of muting colors; however, what often does not get discussed are the costs associated with playing the game, the game actually being played, and the things one is not willing to lose throughout the course of the game. 
These reflections on the impact of personal sacrifices were powerful and illustrated the other side of the lived experiences for Black administrators that is often not discussed. Based on the realization of these personal sacrifices, it became even more significant to understand the driving force that leads to these realities. That driving force is the mantra--we have to work twice as hard to be half as good.

\section{Work Twice as Hard}

Approximately $89 \%$ or 8 of 9 of the participants referenced the importance of working twice as hard as Black administrators in HWIs. It was the most salient theme in the data coding process. There were no direct questions in the interview protocol related to this belief, but the theme was reflected in the majority of the interviews. Collectively, all of the participants could trace this philosophical ideology either from their early childhood memories or based on a lived or vicarious experience they encountered along the way. George simply stated, "You just have to be better. However better is defined, you just have to be it. The necessity to carry myself and comport myself in a manner that always engenders respect. But it's a lonely existence." This working twice as hard mentality is not just about being better; it actually costs--sometimes it costs more than many Black people could afford to give (Coates, 2012, 2014). Eric provided an interesting perspective on why he lives by this particular saying in the following statement:

My friend got engaged this summer in New Orleans, and we went on a slave plantation tour. It was eye-opening to us. One of the tour guides had this saying, which I've taken to use for my dissertation; We worked from can't to can't. We were like, 'What does that mean?' He talked about how slaves would work from when they couldn't see until when they couldn't see--so, from dark-to-dark. It's really inspired me to have that same work ethic because of what I feel my 
ancestors have done for me to put me in this opportunity.

What Eric's reflection illustrates is the reality of the violence forced upon the Black body during this slavery. In spirit of some of the scholars of afropessimism (Hartman, 2007; Patterson, 2018; Wilderson, 2010), this statement shows how the afterlife of slavery still haunts Black people in the context of work today. Working from dark-to-dark meant the slave had no life and had very little time for themselves outside of the confines of their free labor. What is missing from Eric's statement is the realization that Black people did not have a choice during slavery to determine their work schedule. By not being considered human, slaves were subjected to the harsh working conditions that deprived them of their freedom, family, and livelihood. Even though Eric expresses great admiration in thinking about the strength of his ancestors, this way of living has costed him. Eric goes on to reveal the following:

I think that's the Black tax in higher education that we see. Every position that a person of color is in is a dual role. Or . . . a lot of times, I'm sought after for advice--whether it's advice, finances, emotional, spiritual. It's so taxing on me. I was telling this to my wife earlier because I feel like for the first time in my life, I'm not in control, and I've reached the highest stature of my life. I feel like so much of who I am is giving back to everyone. I'm trying to be something to everybody and can't be anything for myself.

When I look at my days, the only time I have to myself is truly in the morning when I take a shower and at night when I take a shower. It's the most tranquil and peaceful space because no one can call me or ask for a request. I still take that pride to lift as you climb, but I feel like we're the only race that uses that statement, lift as you climb. If you really break it down what that means. If you 
think about climbing a 20 -foot wall and trying to carry a 100-pound piece of luggage on your back, it's strenuous and you're going to break at some point. I think I've hit that breaking point in my wall. I'm just continuing to climb, but it's getting harder and harder as I get nearer to the top of where I want to be--my dreams and aspirations to get there--because I'm picking up more and more luggage. My 100 pounds feels like it's about 500 right now.

Eric described the invisible labor clause (Melaku \& Beeman, 2020), which is the toll marginalized groups experience as a byproduct of existing in white spaces. Previous scholars have written about the pervasiveness of the taxation and racial opportunity costs among historically marginalized identities (Perry \& Pickett, 2016; Valverde, 2003; Venzant Chambers \& Huggins, 2014). This lived experience of the work twice as hard mantra resulted in a deep level of exhaustion. For many slaves, living by this standard was forced upon; for many Black people, living by this standard is a choice.

In my interview with Fred, he spoke intensely about the ways this work twice as hard persona was a part of his everyday existence. In fact, Fred referred to it as such:

I still live by the $200 \%$ rule. Still, every day I feel as though in order to be equal in the cabinet, I got to do twice as much and do twice as well and be twice as prepared. That doesn't go away just because you get to the senior position. It might even be magnified because you have reached the senior position, because it's not that you got there because you deserve it. Now you have to show that you still deserve it, because I recognize that if I don't succeed, that means the person coming behind me can't look like me. Right? Because we can open doors, but we could also close them. But we are, in general, surrounded by mediocrity, and we 
have to be excellent to be equal to that. That's bullshit, but I live with it every day. What was intriguing about Fred naming this phenomenon was that I saw it play out firsthand during my campus observation with him. We were in his office preparing to head to a cabinet meeting. I was quietly observing from his office couch, directly adjacent from the desk. Fred is gathered several large binders. As we headed out of the office for the meeting, I offered to assist him in carrying the documents. Fred declined the offer because he already had a bag near the door big enough to store them. Upon arriving at the meeting, Fred introduced me to eight white administrators, five white men and four white women, as his mentee who was shadowing him to learn more about senior-level administration. Everyone greeted me and the meeting commenced shortly thereafter. Fred stacked all of the binders he brought on the desk. I noticed that everyone else in the conference room brought their laptops except for one of the administrators who had nothing on his desk. Everyone's attention went to the PowerPoint on the screen. As they navigated through the material, every time there was a question about something Fred not only answered but physically pulled out the appropriate binder and passed it around the room. We returned the office later in the afternoon and I shared my observation with Fred. I wanted to know why he chose to bring all of those binders instead of bringing his laptop to the meeting earlier. Interestingly enough, Fred laughed and shared these sentiments:

Yeah, and part of that's intentionally a habit because I don't like to print stuff. Right? But if I show up with my laptop, the assumption is I'm not paying attention. The assumption is I'm checking emails. Right? The assumption is not that I've pulled up the materials on my laptop, which actually would be my preference. I don't want to carry this tree around. Right? That's oxygen. That's oxygen I'm taking from the world. Right? I care about the environment, but I also 
know that I walk into that high-level meeting where there are seven vice presidents, including myself, a couple associate vice presidents, that I better be prepared. Not only do I need to be prepared, I need to look prepared. Right? That's exactly what that is. That's every day of my life. I can't half-step--none of that. I can't half-step. So, yeah, you saw it firsthand this morning. I don't even really think about that.

Fred admitted that showing up in this way is not even something he thinks about anymore. It happens just as natural as the air he breathes.

Black administrators have to work twice as hard to get half of the credit and accolades of their white counterparts. Medgar shared the following to support that statement:

They're not going to pick you as an African American to be dean if they think you're going to be average, so you've got to be the star, and is it fair? No. The reality is there are many average deans who are not Black.

This statement made by Medgar was a belief shared by three other participants of this study. In my interview with Malik, he conveyed, "In any space, you ought to know better that your record is going to be under scrutiny more than someone else. And that comes with the territory when you step into these white spaces."

I made the statement earlier that living by this mantra was a choice for many Black people. The term "choice" was appropriate in terms of the ability to choose freely to make a decision; however, it was not exactly accurate. Anti-blackness necessitates that Black people are always in the afterlife of slavery. Under this guise, how can embodying this way of life truly be a choice if it is embedded in one's mind as early as childhood? Entrenched with this discussion, Malik went all in to share this reflection: 
But being Black, coming into these white spaces really employs you to reach beyond your community and what you already know, so inherently, what my mother told me when I was very, very young was this age old attitude; if you're Black, you have to be twice as good: to be as good is absolutely true. Because if you go to matriculate at these white spaces, not only do you have to sort of be familiar with your own domain and your identity, but you have to know others as well ... I've got to get the job, I've got to do my job, and then make others comfortable with me having the job. It's never in the job description, but it's inherently in my mind what I have to do if I'm going to be effective in this space because of the population that I'm dealing with.

Michael offered a very similar perspective during my interview with him. As he was sharing advice for aspiring Black administrators, Michael stated the following:

The other bit of advice that I will tell you is this--it's the advice that your parents gave you and mine gave me throughout my life and it has still been the truth-you've got to work twice as hard to be considered half as good.

Ahmaud contributed to this conversation in his articulation of what working twice as hard meant in his life as a Black administrator. Ahmaud said, "I think it was yet another reminder that academic leaders of color, I think, are held to a higher standard than their white counterparts, and it's something that we have to be ever mindful of." During my interview with Ahmaud, he acknowledged the origins of his understanding of this reality came after watching the white officers of the Los Angeles Police Department who beat up Rodney King in 1991 get acquitted for their crime. The intersection of this historic event and the racial tension that followed was the catalyst for his parents to have an important conversation. Ahmaud emphasized his thoughts: 
I'm blessed to live in a household where I had two parents, two very strong parents who poured into me. And they always impressed upon me that you're going to have to work twice as hard. I remember always hearing that saying growing up. They didn't always explain it, in fact, they rarely explained it, probably not until I got to high school. And that's where being introduced to this notion of differential life outcomes based solely on race basically.

This work twice as hard indeed had a cost and its implications linger with Black administrators in their everyday experiences. Martin offered this testimonial that captured the essence of this sub-theme:

I always felt like I had to prove myself. But I made a choice long ago based on the way I was raised, that you're going to have to be twice as good, twice as quick. If you want to get somewhere, you're going to have to be twice as outgoing, twice as friendly. All of those things. And so, rightfully or wrongfully, I adopted that to a certain point over the years. Right? But I also saw how that impacted me in other ways, how that impacted me in stress, how that impacted me in anxiety, how that impacted me on weight gain, how it impacted me while developing a fake it till you make it portion. Technically, when I look back, I didn't have to fake anything. because I was always who I was, but I felt as though I had to convince others that I had a right to be in the space even though I already had a right to be in the space .... I've always been the kind of person that says 'sign me up for the madness' because I don't know where my next opportunity is going to come from because I'm probably guaranteed to have fewer opportunities because I'm black. 


\section{Theme 2: Blackness}

Blackness resonated as the second overarching theme from the data. Dei (2018, p. 129) posited that "Blackness symbolizes how the Black Body is read, resisted, affirmed, and contested in multiples spaces" throughout the course of shared histories. The essence of Blackness is the thing anti-blackness seeks to destroy. It would make sense that a natural mechanism for disrupting anti-blackness would be through the manifestations of the Black identity. Though previous research about Black administrators focused on tokenism (Brooks \& Arnold, 2013; Comer, 1978; Davis, 1994; Durgans, 2002; Harvey, 1999; Jones, 2001; Valverde, 2003; M. C. Woodard \& Harris, 1978), the existing literature failed to capture what it truly means to not be a token just because one is perceived as a token. Collectively, all of the participants expressed their untethering connection with their Blackness and the ways their identities have shaped their sense of purpose and community. The sub-themes that emerged from the data were Black and proud, Wakanda, and hiding in plain sight.

\section{Black and Proud}

Dei (2017) expressed loving Blackness as a significant form of resistance because it challenges the anti-black thought, which stamps Blackness as something incapable of being loved. Approximately $67 \%$ or 6 of 9 of the participants proudly shared the reverence that radiates from their Black identities in relation to being in white spaces. Fred stated, "I'm Black before I'm anything. I'm a Black father. I'm a Black husband. I'm a Black administrator. I'm a Black son. I've always been aware of my blackness, as far back as I can remember." What Fred described is the representativeness of Blackness as a construct defined by one's intersecting identities (Wright, 2015). Michael expressed a similar perspective in stating the following:

My thoughts, feelings and actions ... there's not one second of a day that goes by 
that I don't realize or remember or appreciate that I'm Black. I'll say that again. Not one second of the day goes by unless I'm sleeping that I don't realize, remember, or live my life influenced by that. Even if I think about my leadership and who I am, it's because of my experiences so I can't even separate the two. So, when I'm making decisions at the workplace, I'm working them as a Black man. When I'm making business decisions, I'm making them as a Black man. When I talk to people, I realize I'm talking to them as a Black man.

Michael accredited the ways his Black identity informed his personal and professional modes of being. This trend continued to be conveyed by the participants as Martin expressed the following:

I believe my blackness is the one that is seen before I can even have an impact on the space. I never sacrifice or lose my blackness because I understand that I'm just like another Black person, who just happened to have some opportunities that have been afforded to me that maybe not everybody has had an opportunity to have afforded to them.

Ahmaud not only acknowledged his Black identity as a critical lens for how he sees the world but recognized its impact on his reason for being a Black administrator. Ahmaud expressed the following:

Well, it is among the primary lens through which I view the world, right? My Black identity is a very salient aspect of my identity. It shaped much of my experience from childhood to present day, and so I celebrate it. I celebrated it ... it is part and parcel of what inspired me to do this work. For me that's not negotiable. Like, I'm hard pressed to imagine a scenario in which I would need to, 
or I would compromise my black identity to be able to do this job. If it ever comes to that, I'm better off just giving up my seat.

The presence of Blackness was a part of their everyday work experience because it is deeply woven into the fabric of who they are as people who identify as Black. In fact, this awareness of their Blackness has often been the barometer used to determine how they are treated in comparison to others. George offered this insight:

How my identity is shaped by my blackness, for me, it's always been a sense of pride. I've never felt less than anyone else because of my Black skin. Now I may have felt like I didn't have the same access to resources that other folks had as a consequence of my environment or mostly my family environment, but that did not deter my thirst for knowledge in education.

Blackness is a central component to how these Black administrators experience the world. Previously, the literature focused heavily on the concept of tokenism; whereas, this study offered a counternarrative for Black administrators steeped in their identities. Medgar simply stated, "You might not identify as Black, but the world identifies you that way."

\section{Wakanda}

The expression "it takes a village" is a critical ingredient to the success of Black administrators. It is important to build and sustain a community to push, challenge, and inspire given the complexity of their work as Black administrators. Previous research highlights the importance of mentoring (Guillory, 2001; Jackson \& Flowers, 2003; Jones, 2001; Lewis, 2007); however, this study sheds light on the importance of building a tribe of supporters known as Wakanda. The concept of Wakanda derived from the movie Black Panther (Coogler, 2018) which featured an all-Black environment where excellence was the standard. It must be noted 
that Wakanda is a relatively new concept, but Black people have been creating sanctuary spaces for resistance and support in white spaces since the Underground Railroad during slavery (WattsJones, 2002). Six of the nine (66.7\%) participants spoke to the significance of having a council of Black colleagues in their Wakanda. Trayvon expressed the following sentiment to justify the need for this space:

I think that I have really been lonely in the space. I think you have to have somebody who could guide you through the advanced levels of whiteness that happen at predominantly white institutions at the high level because what you train for might not be exactly what's going to get you ready for what you're looking at.

Black administrators require an outlet to not only navigate through but process their experiences with others. Often, this council serves as a sounding board to ensure that all are not falling into the traps of the system. Ahmaud asserted his thoughts:

I was blessed by the opportunity to develop some profound mentoring relationships that helped me stay on that path and continue to advance professionally. They are people that I can call on with confidence to talk and that I know will give me sage advice; they won't sugar coat anything. If I'm wrong, they'll tell me I'm wrong and so, I can trust that they will give me advice, and they won't just tell me what they think I want to hear. Right? They truly have my best interest at heart. So, there's that network of professional mentors and I check in with them regularly. In fact, a group of us meet on a monthly basis Via Zoom just to support one another. What are you dealing with on your campus? Because often, what I have found in this role especially, being a Chief Student Affairs 
Officer is very isolating. There are a few people that you can talk to candidly about the challenges you're experiencing in your role.

The spirit of this Wakanda for Black administrators is rooted in love. Michael thought it was important to convey, "We all have our crew and we tell each other that we love each other all the time, because there is just no way that we could do without it; you know what I mean?" Fred simply stated, "I have colleagues around the country that I call on." During my interview with Michael he said,

I also have a set of people who are outside the institution who have served in leadership capacities across the country who I bounce things off of. Or, if things don't seem quite right, I make a call to them or we get together at various meetings, and you know, I'll just have my plate [list] ready to chat with. But you don't really want to wait that long with some things, so you just get on the phone and call. I have some colleagues who are retired now who love to chitchat about how they might've handled something, or to just listen because many times you're not asking for advice, you're just saying, you know, 'Man, I just want to be heard right now.'

In my conversation with George, he discussed the importance of seeking Black allies, faculty, and administrators on campus. That's really important. Even if the connection was limited to a brief, 5-minute conversation or connecting for lunch, he noted them as a reaffirmation of all of them being in the work together while trying to navigate the space as best as possible. George elaborated by saying the following:

I call it my funky monkey moment. I get to one of those moments and I try to ... there's a certain individual on campus who I will talk to; well, actually about two 
or three, and I say, 'Hey, I just need to let you ...' and they're all Black men. I say, 'I just need to let y'all know this is happening right now and this is how I'm feeling right now. So, I need you all to walk me off the ledge.' Or to walk me back from the ledge, rather, because it's a little ... right now I'm feeling a little crazy about some of this madness.

Given that all the participants of this study expressed that HWIs are not safe places, the formation of a Wakanda is a liberatory act of resistance that fulfills the need for support (Hooks, 1990; Watts-Jones, 2002). Wakanda is so important, both in theory and practice, and needs to be a critical source of support and mattering for Black administrators.

\section{Hiding in Plain Sight}

All of the participants conveyed that despite the challenges that come with their roles as Black administrators, they could not imagine themselves doing anything else as a professional calling. Seven of the nine (77.8\%) participants acknowledged that it was their meaningful exposure and impact from a Black administrator that inspired them to become one. Although anti-blackness represents an omnipresent condition of the Black administrator's lived experiences, it does not represent the totality of their lived experiences (M. J. Dumas, 2018). The answer cannot be to abandon these roles because Black students are attending these HWIs and looking for Black administrators to transform their lives. Black administrators influence policies, practices, and procedures that directly impact the quality of the higher education experience. The participants of this study spoke to the power of how they resist and disrupt their anti-black lived experiences by hiding in plain sight. Seven of the participants spoke directly to how this concept played out in their roles as Black administrators. 
In the movie, the Matrix (Wachowski \& Wachowski, 1999) Neo, the main character, is offered two pills: one red and one blue. The red pill was designed to reveal unpleasant truth, which would take one out of the Matrix. The blue pill was created to maintain ignorance and the world as one knows it would remain unchanged. As I interviewed Michael, he was passionate about discussing the necessary choices he believed Black administrators needed to decide for themselves. He acclaimed the following:

All of you are going to have to make a choice. One part of your choice is you're going to continue to be militant and fight the battle, or whatever. And others of you are going to conform and be able to work behind the scenes. And there's nothing wrong with whatever choice you make. All we ask is that you just know what's in front of you. Just so you know it's in front of you, because there's pros and cons to both ... I guess things really don't affect me or shock me the way they do others because I expect them. But what do I do? I work behind the scenes to make things equal and better without folks knowing about it.

Michael discussed how he was extremely militant earlier in his career. He pushed and fought for every cause every chance he got. He noticed that it made his work harder and he rarely got anything accomplished on behalf of the students he served. He eventually made the choice to shift his approach and he decided his Black identity was precious. Ultimately, he made the decision not to share the most deeply salient part of his identity; however, all of his decisions were strategic and rooted in his Black identity.

For Michael, he considered himself to be the house slave working directly under the master to find ways to free his people--by any means necessary. Sexton (2011) amplified Michael's words by saying, "Black life is not lived in the world that the world lives in, but it is 
lived underground, in outer space" (p. 28). Michael advocated against the notion of double consciousness or twoness (DuBois, 1897; Pinderhughes, 1989) because when one is firm in their identity, they cannot be moved even while navigating between two seemingly different worlds (Caldwell \& Stewart, 2001). The Matrix was a form of resistance against all forces that sought to restrict possibilities for creativity and liberation (Boyd, 2004). By hiding in plain sight, Black administrators have developed strategies for their survival and persistence and for future, aspiring Black administrators and the students they serve.

Trayvon used this concept as a form of resistance by concealing aspects of his personal life and accomplishments from his workspace to ensure they could not be weaponized against him by his peers. Trayvon explained his circumstances:

I was hiding in plain sight, which is what I do well. And I've learned to do that well because I have found if talking about the things that I want to do, even when I test the waters, people either will try to use that against me, or they will change that energy towards me. So, what I have found is that things go a lot better when I just don't share. I think what I'm protecting is the ability to just be me. I think the times when I've just tried to be me at work and share openly, it didn't go well. He (Trayvon) views it as not suppressing his identity but protecting it from people and spaces that mean him harm. Malik, George, and Ahmaud expressed very similar sentiments as Trayvon on this topic. Malik contributed the following thoughts:

I won't try to dispel that. I'm a leader of very few words when I'm in these larger white spaces because I think there's an expectation of you to reveal who you are, right? But I'm trying to be very strategic about what I say and when I say it, so it has more impact and more meaning. 
Malik used his words and demeanor strategically as a form of armor to protect himself. For George, he conveyed the following:

But I wear my blackness as a source of pride, and I'll be honest with you, sometimes I use it as a form of defiance. Sometimes I use it as a form of aggression--not physically or pushing it but with just being stoic and stern in my blackness--kind of like don't mess with me.

Blackness is fundamental to everything these participants do, but they have reclaimed their power in how they choose to display it. Ahmaud offered his position:

It's expected that you will acculturate to the environment that you are occupying, that you will comport yourself in a manner that doesn't cause others to feel threatened. That's necessary for you to be perceived as effective in your role. I think you have to really be intentional about having boundaries. That's kind of my language in terms of what you choose to share, when, and with whom. I wouldn't describe myself as having political ideology or beliefs that differ drastically from the individual [Dr. Riley] at the center of that situation, but I wouldn't share them.

All of these responses demonstrated the importance of having agency to define oneself for these Black administrators.

Medgar takes this concept to a deeper level as he introduces the concept of stewardship for Black administrators. Medgar highlighted stewardship in this manner:

You're a steward, and the steward is never going to be loved like a king or queen; but the steward is necessary to maintain the organization. And so, I always just remind people that someone else is going to come in and need to use this place to advance their intellectual opportunities and the opportunities they might have 
postgraduation. So, what can we do as stewards to make sure that it exists, and it exists in such a way that it is very useful, and where it's really the best it possibly can be?

Medgar proceeded to discuss how dissonance comes when Black administrators have not accepted how these systems work and proceed to frustrate themselves fighting an unwinnable war. In Medgar's elaboration, he outlined the following:

Well, number one, from a psychological point of view, I'm not in distress. So a lot of people I see walking around in distress, and generally when I see that, I realize that they have a total misconception about where they are: that they really think that they're owners, and are walking around acting as if, as an owner, they merit certain considerations--including the consideration related to just merit-based decisions. This is what drives many people insane because they're passed over for things, don't have the same opportunities, and don't understand why. They internalize the hatred that is being thrown upon them, or the low-key bias that happens, or even high-end bias. It happens against them, and I think it has a tremendous psychological effect, and drives many people to poor health and other kinds of things.

Eric acknowledged the undue stress he placed on himself, but also believed his presence as a Black administrator is disruptive to anti-blackness. He described the following: I feel like this work is my purpose in life. I think a lot of times, as a Black man, I put on this unnecessary stress, but I think it's real. I think sometimes one of my purposes is to disrupt the narrative of what people perceive Black people to be. In making the decision not to allow the job to affect his mental psyche, Fred offered the 
following outlook:

I believe that bad days are a mindset. I deal with hard issues. I'm one of the very few people at my institution ... that truly deals with life and death. Right? This weekend I dealt with a death. That's tough. I don't let it impact my psyche, as much as I can, because I have too many things to allow my job to control that. If I allow my job to control it, that's how I show up as a dad, how I show up as a husband, and that's not acceptable to me. It just isn't.

Each participant candidly expressed how he used his ability to hide in plain sight to challenge and fight against the marginalizing experiences of their life at HWIs. The critical component for this concept was their ability to assess the best strategy needed to approach the work. For Black administrators, taking a red or blue pill is not needed; the Black body deemed as non-human could never exist in the Matrix. Blackness allowed them to exist in both worlds with the ability to navigate in between at will.

\section{Summary}

In the chapter, I unmasked the anti-black lived experiences shared by the nine participants revealed through the data analysis process. A detailed description of the participants and the significance of their pseudonyms were provided. Then, I focused on the common themes and sub-themes that emerged from the data through the utilization of initial coding, In Vivo, and focused coding. The guiding research questions for this study were answered through the themes and sub-themes drawn from the in-depth participant interviews, referred colleague interviews, and the campus observations. In Chapter VI, I conclude my findings by discussing the implications and recommendations. 


\section{CHAPTER VI: DISCUSSION AND IMPLICATIONS}

"My life amounts to no more than one drop in a limitless ocean. Yet what is any ocean, but a multitude of drops? David Mitchell, Cloud Atlas (Wachowski, Wachowski, \& Tykwer, 2012)

The purpose of this study was to unmask the ways that senior-level Black administrators' process, navigate, and make meaning of their lived experiences and anti-blackness at HWIs. In this chapter, I merge the significant findings from this study with the literature pertaining to Black administrators at HWIs. Nine participants contributed to this study. The data collected materialized two themes that spoke directly to the lived experiences of Black administrators. The themes reflected the depth and complexities tethered to the Black administrator's world at HWIs narrated by the participants. I used dual guiding frameworks, BlackCrit and marginality and mattering, to navigate and analyze the data. I finalize this chapter with the limitations of the study, suggestions for future research, and the summary. This study was guided by the following research questions:

1. How do senior-level Black men who are administrators navigate anti-blackness at HWIs?

2. In an HWI context, what extent does anti-blackness affect Black men's ability to lead?

3. In what ways do Black men administrators use their Blackness to navigate HWIs?

4. How do Black men make sense of their administrative role and responsibilities in an HWI?

5. How do Black men administrators prepare for the opportunities and challenges of being a senior-level administrator at an HWI?

\section{Interpretation of Findings}

This study was designed to uncover the ways Black administrators navigated antiblackness in their lived experiences at HWIs. The totality of the data collected in this study 
expanded my perspectives on the complexities of being Black while leading in white spaces. The participants weaponized their Black identities to persist, resist, and disrupt anti-blackness at HWIs. Their presence in these spaces created a form of resistance within itself. Collectively, their experiences and perspectives generated two themes for this study.

\section{Themes}

Two common themes, anti-blackness and Blackness, were illuminated as Black administrators at HWIs processed, navigated, and made meaning of their lived experiences. The common themes and sub-themes for each are described in detail in the following sections:

\section{Anti-blackness}

All the participants experienced anti-blackness at HWIs; however, as predicted, they did not have the language to draw the parallel between those experiences and anti-blackness. Sundown institutions, personal sacrifices, and work twice as hard emerged as the manifestations of anti-blackness at HWIs.

Sundown institutions. All the participants articulated that higher education is not safe for Black administrators. I argued, based on the experiences shared from the participants, that institutions of higher education disguised as safe spaces exist and are considered sundown institutions. Derived from the concept of sundown towns, sundown institutions have also underhandedly used violence and intimidation to reject Black people from white spaces (Loewen, 2018). Clearly, no visible signs denied Blacks access within HWIs; however, daily rebuffs occurred to convey the restrictions--no Blacks allowed--to the participants of this study (Hartman, 2017). This study deliberately used the language of HWI instead of PWI because "the term PWI eradicates the historical dehumanization of enslaved peoples as property, who built and maintained the upkeep of these 'prestigious' and predominantly white institutions and 
universities" (Johnson, 2019, p. 1). Black administrators continue to build and maintain these institutions by way of their leadership in spite of the harsh reality that, at any moment, they could be symbolically lynched as Dr. Jack Thomas (Stripling, 2019) and Dr. Jamie Riley (Bolling et al., 2019). Contrary to what previous literature portrayed through the concept of tokenism, this study revealed the participants are not delusional or ignorant to the fact that HWIs are not designed for them. All of the participants stated they were not surprised after reading about Dr. Riley's resignation. To better understand how deeply engrained anti-black messages are embedded in our society, Fred shared a personal fear he had at the thought of having a son when his wife was pregnant. This fear was rooted in continuously experiencing Black bodies being violated, executed, and extinguished just for being Black (Curry, 2017). This fear fuels the antiblackness that permeates in all spaces, but particularly within HWIs. This is how anti-blackness is demonstrated within sundown institutions.

Personal sacrifices. The majority ( 7 of 9) of the participants spoke directly to the personal sacrifices they made on their ascent to senior-level administration leadership. The greatest sacrifice noted was family and personal relationships. The scarcity of time caused many of the participants to prioritize work over other aspects of their lives. Medgar and Malik were intentional about not compromising themselves or family for work; however, Malik recognized that the day might when compromise must happen to achieve upward mobility. The participants showed that there was a cost associated with leadership as Black men. These personal sacrifices moved the participants into isolation where the work became the center of their existence. Neglecting their families and personal relationships nearly deprived them of the most important driving force in their worlds--their critical support spaces. This study uncovered this phenomenon to serve as a cautionary guide for aspiring Black administrators to be hyperaware of 
the kinds of sacrifices being made and the impacts of those decisions.

Working twice as hard. Granted, the concept of working twice as hard contributed to the work ethic that helped the participants attain their senior-level administration positions, but it also created a reality where these participants are possessed by the ghost of the plantation. Eric highlighted how slaves, under the chattel system that rendered the Black body as property and worked from dark-to-dark (sunup to sundown). This work style was forced upon slaves; whereas, many Black administrators today embody this mentality even though it has associated costs. At the crux of this expression was a deeply rooted belief that working twice as hard, or just being better, as George phrased, would shield these Black administrators from the public, symbolic lynching they witnessed of other Black administrators. They recognized it could be any of them suffering the same fate. The participants of this study acknowledged that working twice as hard was essential, but they also recognized the implications of trying to prove one's self-worth in a society that renders them as property.

\section{Blackness}

Black and proud. The cure of anti-blackness is Blackness. Blackness is expansive; it is nothing and everything at the same time (Wright, 2015). It has and will continue to transform as Blackness cannot be quarantined or destroyed. Blackness is a spirit and an energy; constantly flowing and evolving. The participants of this study celebrated and rejoiced in their Black identities. Despite the anti-black experiences they had to navigate for being Black, all of them cited it as a grounding source of pride and a non-negotiable sacrifice. All the participants boldly declared the HWIs had an impact on their personal lives and career paths. However, Martin expressed that sacrificing or losing his Black identity was not an option. 
Wakanda. Black administrators need to support each other as they navigate antiblackness at HWIs and Wakanda is source of safety and healing that supports that notion (WattsJones, 2002). Every Black administrator needs their own Wakanda--a community of people to love, uplift, challenge, and to be authentic among. With Wakanda serving as a homeplace (Hooks, 1990), Black administrators have the opportunity to heal some of the wounds caused by the daily inhalation of anti-blackness at HWIs. Connecting with Black professionals who serve as thought partners, wise council, or someone to whom one can vent is one of the benefits of Wakanda. The participants of this study expressed how they used their Wakanda as a form of resistance. Ahmaud attested to hosting monthly Zoom calls with other Black administrators for guidance and support. Michael testified to the importance of showing and expressing love to the Black administrators in Wakanda because it would be impossible to succeed without them.

The system of anti-blackness created an aura that reinvigorated the notion that Blackness remains property to be owned for commodification of whiteness. Pushing back (Ore, 2016) requires the Black lived experience to be reframed. We revolt because it is impossible to breathe submerged in the pollution of anti-blackness (Fanon \& Philcox, 2008). The afterlife of slavery, referenced by Sharpe (2016) as wake work, means bringing to consciousness all that Blackness entails in the 21 st century. In other words, how different would our experiences look if we accepted anti-blackness as our foundation for walking, standing, and speaking. This is what was meant by racial realism (Bell, 1992b); by accepting that Black people will never be human in this society, an opportunity to imagine what could exist outside of the realm of humanity has been created.

Hiding in plain sight. In the context of Black men in higher education, the system will continue to engage in necropolitics (Mbembe \& Corcoran, 2019) as it was designed to do; 
however, Blackness must continue to deliver reimagined manifestations through resistance and Black life making (Dei, 2017; Mustaffa, 2017; Sharpe, 2016). The participants of this study showed what this manifestation could look like when hiding in plain sight. By hiding in plain sight, the participants of this study developed strategies for survival and persistence in these white spaces. In this study, I argued that Black administrators did not require any pills (blue or red) to leave the matrix; however, when defined by Ross (2019), the Black body was deemed as property and stripped of its humanity, therefore, eliminating them from ever being a part of the matrix (Ziyad \& DuWhite, 2019). Black administrators are free to travel between two worlds when it is acknowledged and accepted that Blackness renders an opportunity to reside in both worlds.

Institutions of higher education are sites of suffering (M. J. Dumas \& Ross, 2016) for Black administrators; however, the participants conveyed that the solution was not necessarily to abandon these spaces. "Black people are fugitives, not because we have escaped enslavement but because we have escaped the escape. We do not have to run anymore" (A. Woodson, 2019, p. 19). The participants' presence in these leadership roles at HWIs was within itself a form of resistance. Viola Davis said, "My entire life has been a protest" (Saraiya, 2020). The participants in this study dedicated their lives and careers to portraying the nobility of the Black man; thereby, resisting against the anti-black racism in the existence of their lived experiences.

\section{Implications for Theory and Practice}

Chapter III included detailed information on the two guiding frameworks used for this research study: BlackCrit and theory of marginality and mattering. These essential frameworks were complimentary; together, they helped to highlight vividly the lived experiences of the Black administrators at HWIs within this study. 


\section{BlackCrit}

BlackCrit centered the entire study on Blackness; thereby, uplifting the depth and scope of the participants lived experiences as Black administrators at HWIs. It was important to examine these experiences from a Black perspective to unmask anti-blackness. This was achieved by revealing the origins and modality of anti-blackness, as outlined in Chapter II. This study provided a foundational description of anti-blackness to situate its existence within the context of Black administrators at HWIs.

This study presented a new path rooted and managed in Blackness. In the words of Moore and Wagstaff (1974), this study was,

Discriminatory, biased, and prescriptive. It is discriminatory because it focuses primarily on Black educators [as administrators]. It is biased because it reports and discusses only the perceptions of Black faculty members and administrators in predominantly white colleges and universities. It is prescriptive, we hope, because it provides information and techniques that may be used by the academic [and higher education] community in attempting to relate to its newest members, Black educators. (p. ix)

By using BlackCrit as one of my guiding lenses, I was not researching whether anti-blackness against Black administrators at HWIs existed, but rather how Black administrators thrived despite its existence. All the participants were unapologetically Black and very proud. They thrived by using Blackness as a form of resistance to the anti-blackness experienced at HWIs. Furthermore, "Black identity is affirmed both as a racial consciousness and political awareness of what it means to be Black in a White-dominated society and the resistances that are required for Black survival" (Dei, 2017, p. 67). The participants of this study demonstrated their 
embodiment of their Black identities that called them to serve as leaders and compelled them to use their positionality to transform the lived experiences for Black students, faculty, and administrators at HWIs.

\section{Theory of Marginality and Mattering}

Because of the ubiquity of anti-blackness, the participants of this study were unable to recognize and verbalize their experiences using the language of anti-blackness. This nonreaction was anticipated by me prior to the study being conducted, and this framework was selected to fill the gap. Marginality and mattering were concepts that the participants were familiar with and could articulate their experiences through these lenses. Together they provided familiar language to explain the breadth of their experiences. The two common themes that emerged from the data reflected this prototype: anti-blackness (marginality) and Blackness (mattering). Analyzing the data yielded sub-themes that aligned with the two common themes. The results of this study revealed that both anti-blackness (marginality) and Blackness (mattering) experiences existed at the same time considering the perspective of Black administrators at HWIs. Furthermore, this study pioneered the utilization of the theory of marginality and mattering for study participants not identified as college students. This study opened the door for future studies to consider applying this framework in examining other non-students in higher education environments.

\section{Limitations}

As I reflect on the entire research experience, I am extremely proud of the knowledge created, the results rendered, and the overall experience. A qualitative research approach was the most fitting selection for this study because it allowed the personal accounts of the participants' lived experiences to be captured in their own voices through the interview process. As true for any research study, it must be acknowledged that there were limitations to this study. Limitations 
identified for this study were the complexity in scheduling campus visits and the participants' openness to being vulnerable.

Using field observations was a vital component to the study and helped to preserve the integrity of the data collected; however, the coordination of the campus visits was difficult. A new academic year had begun, and the participants were extremely busy. Conducting the interviews by video conferencing was not an option because it would have compromised the design of the study. As mentioned in Chapter IV, there were two other prospective participants who were not able to commit to every aspect of this study so they could not move forward as participants for this study. All the participants for this study were accommodating, and together we were successful; however, managing nine campus visits, conducting participant interviews, and interviewing the referred colleague with discretion did present some undue stress on me.

In addition, the participants of this study shared invaluable knowledge about their lived experiences at HWIs. Maintaining confidentiality and avoiding compromising situations posed challenges for the participants—-because for some, hesitation was an initial response during discussions. There was a level of trust and vulnerability required to unearth some of these experiences. Given that all the participants deemed the higher education environment as not a safe space for Black administrators, they shared their experiences to the best of their ability. However, it is probable that they held back in some of their responses. Confidentiality of the participants' identities was upheld to the highest standards possible in the study, the limitations of trust and vulnerability must be admitted.

\section{Implications for Future Research}

This study provided insight into the strategies Black administrators used to process, navigate, and make meaning of their anti-black lived experiences at HWIs. I hope that future 
studies will use a qualitative research approach to dive deeper into the experiences of Black administrators at HWIs. This study contributes to the existing literature on Black administrators, and I believe future studies must increase to generate even more literature on this topic. This study by itself is a drop of water; a drop of water by itself does not leave a mark on the landscape, but the consistent movement of a tide over time creates iconic valleys, shorelines, and can move mountains. This study joins the collection of the previous studies to continue that movement (Hammonds, 2012; Hester, 2020; Johnson, 2019; Kirkwood, 2018; Lewis, 2007; Pickron, 1991; Rollins, 2017; Scott, 2016; Seawood, 2005; Stokes, 2011; Thompson, 2016; Wolfe, 2010). My recommendations for future research are as follows:

- Conduct research to understand how Black administrators at HWIs define and identify anti-blackness within the context of their roles. This study unmasked the anti-blackness within the experiences described by the participants, but there needs to be a study dedicated to how Black administrators understand anti-blackness.

- Conduct research to explore how Black administrators practice self-care and holistic wellness at HWIs.

- Conduct research that focuses on the intersecting identities of Black men and how those identities impact their anti-black lived experiences.

- Conduct research that examines how masculinity as a social construct influences the perception of Black administrators at HWIs.

- Conduct research that compares the anti-black lived experiences of Black administrators at HWIs and Black administrators at HBCUs.

- Conduct research on anti-black institutional hiring policies as a barrier to increasing the number of Black administrators in higher education. 
- Conduct research to determine how the engagement between Black men who are midlevel administrators and Black men who are senior-level administrators contribute to their decision to pursue vertical leadership.

\section{Recommendations for Practice}

Based on the totality of the data collected from the participants of this study, important recommendations emerged for future practice for future practice that benefit both the HWIs and the aspiring Black administrators.

\section{Institutional Recommendations}

Given that a central component of this study was about HWIs, the following recommendations are offered to radically shift institutional cultures of HWIs to invest more in increasing and retaining Black administrators working in these spaces.

- For HWI administrators and governing bodies to focus solely on strategies to learn about being anti-racist is not enough (Kendi, 2019). An investment in learning about and acknowledging the pervasiveness of anti-blackness is necessary. Until HWIs and its bodies come to terms with their anti-black histories and practices, they will continue to be sundown institutions masquerading as safe spaces.

- Institution administrators need to develop mechanisms for Black administrators to establish meaningful connections with other Black administrators. Programs of this nature could create collaborative support circles comprised of Black faculty and administrators within the institution.

- Institution administrators need to reassess the hiring practices for Black administrators and utilize cluster hiring for Black administrators to increase the number of Black administrators at these respective institutions. It is not enough to speak about increasing 
diversity on public websites and brochures. Dedicated resources are needed to achieve access and retention for Black administrators.

- Institution administrators need use double-loop learning strategies to examine and critique their anti-black policies and practices. Williams (2013) defined double-loop learning as "entities (individuals, groups, or organizations) question[ing] the values, assumptions, and policies that have produced an unsatisfactory or incomplete outcome" (p. 212). In this form of learning, HWIs employees and officers are forced to be more reflective by moving from how to why. It is not about only asking the question; it is equally important to apply the reflections gathered to create innovative changes.

\section{Recommendations for Black Administrators}

The following are recommendations for Black administrators to navigate and disrupt antiblackness at HWIs:

- Call it what it is--anti-blackness. This pandemic gets its power from its invisibility. When you see or feel it, say it. This deadly ideology must be unveiled so that it can vanquished.

- Be Real Black for Me (M. J. Dumas \& Ross, 2016). There is strength in your Blackness. Even though there are many messages that seek to convince you the opposite, just be you. If you must wear a mask (e.g., code switching), never forget your real face. Celebrate and take pride in your Black identity.

- Take care of yourself while you are taking care of others. Do not set yourself on fire just to keep others warm. Develop, utilize, and sustain strategies for your physical, mental, spiritual, and emotional well-being.

- Build your Wakanda! Nurture mutually beneficial connections that can serve as your sources of strength, thought partnership, healing, and accountability. Seek community 
from elders and peers alike. Mentorship is only one form of support. Invest in your crew. Call to your ancestors and embrace their guidance as you navigate these anti-black spaces.

- A dedicated conference or retreat focused on unmasking anti-blackness at HWIs and sharing strategies to resist and reimagine these experiences.

- Life in its longest moment is still just a breath away from death. Be present. Celebrate your wins.

- Refuse, resist, and reimagine (Ross, 2019).

\section{Extracted Recommendations from Participants}

In this research study, each participant was asked during the in-depth interview to offer insights or perspectives they believed aspiring Black administers needed to consider. Their responses are as follows:

Trayvon. The only thing I can think of is this; I would probably say you just have to be resilient and persistent. I say resilient and persistent because you have to know what you are fighting for and you got to be grounded and clear in why you want to do this. We create a counternarrative when using the power given to influence change in a positive way.

Fred. Integrity, it always goes back to it. We've seen people fall because of failed integrity, their integrity failed them, or they failed their integrity. Integrity will never fail anyone, but you can fail it. Honesty, accountability, the desire to help people grow, the lack of desire to be in the limelight ... that doesn't mean you can't shine. It just means you don't need to shine. Only credit I can take for some people's work is assigning them something, hiring that person, pushing them, but the work is theirs and so the credit is theirs. Right? I figured if I hire my people, I train my people, I promote my people, I assign them stuff, then I will shine just fine. I 
shine much brighter when the people around me shine and when I rejoice their successes. Shining can be a drug to people. You have to know when it becomes your time to be the light source rather than the receiver of light.

The only other thing I think I would add is use the old heads. They want you to. Don't let the information die with us, not that I'm trying to die anytime soon, but proverbially and literally, I guess. Right? Yeah. I feel as though I'm in a relay race, and I'm getting the baton, but eventually I got to pass it. Yeah, I would love to pass it to a young Black man. But don't be afraid to use us. That's why we're here. We are on the shoulders of giants. Some are foolish enough to also view us as giants. If that's how we'll be viewed, then I damn well better lend my shoulders. I don't have a choice. It's a calling. It's a responsibility, so I offer my shoulders, whether I believe I'm worthy or not.

Eric. I think cultural dexterity is huge: the ability to adapt and to learn how to walk into rooms and understand the climate. I always say when I enter a room, I have to decide whether I'm strong or passionate because sometimes, as a Black man, if I decide to be both, I'll be deemed as walking in the room aggressively. There are certain ideas that I may be strong about, but I can't show that I'm passionate about it because that aggression could turn off my white colleagues. There's that code switching. There's that adaptability. I'll know how to come in and bait them in and not put all my cards on the table. I think an attribute I have to learn is to start celebrating where I'm at currently and living in the moment, because mentally, it's just adding a burden that is unnecessary.

George. I would say be patient. Get your terminal degree. You just need a degree with a letter D in it. But also, never stop being a student of the field. Know your craft. You have to always present yourself and be confident about your abilities. You always have to be willing to 
learn, but you also have to recognize what you do not know and accept that: and not let it rest but learn what you don't know. And I'm not saying you have to be an expert in everything, but you have to be at least mentally conversant in some of things that are going on in higher education.

Medgar. The academy is the original country club, and it's also a medieval environment. So, you have to figure out the various roles of the people in the country club or this medieval environment, and what role do you think you can play in that context. It's very understated and very few people tell you directly what they're doing. Everything's subtext and subtle. If you're not good at environmental scans, looking at relationships, looking at physical plant, and ascertaining what's happening around you, this will be a miserable life for you. You're going to fail. There's no fix. There's no leadership program that's going to help you. I have always said that. I mean, I don't minimize leadership preparation; I think there are technocratic things that you can learn in a leadership program. Are you actually able to be self-reflective? Can you put a mirror up and see who you are? Can you see your weaknesses? The higher you go up in administration, the brighter your weaknesses become.

Malik. Self-awareness, organizational awareness, deference to others, knowing the ethos of the institution, the do's and don'ts, the informal, formal curriculum, and the politics of the institution (i.e., knowing when to network and who to network with)--those are the things that I think are really, really, really important if you want to ascend to vertical opportunities in an organization.

Michael. You better know what you truly want when you come to that path. Student affairs in higher education is no different than what you're going to see out there. So, don't think you're going to come in here and have a true safe space--that's a damn lie! There is no safe space in higher education. In some cases, it's worse. Because at least out there, when the cop spits in 
my face, I know where he is coming from. But these people are going to kiss you and stab you in the back.

The other thing I will tell you and this is not even advice, this is facts. It's not ever going to be fair. It is never going to be fair. That's why I tell people I play the game because people who truly sell out, they think that it's going to be fair for them. Idiots. They don't know. They don't know the evils. My faith is very important to me. And I know I've touched on it a couple of times but find your faith in whatever that is. And it doesn't have to be religious faith, but it can be spiritual faith. Don't let your life be about just a job. Don't do that.

Ahmaud. Perseverance, humility, hard work, and work ethic--I think one has to be selfaware. You really need to understand what your strengths are and what your limitations are and not be afraid of your limitations. You have to be relational, recognize the power of relationships, and you have to be able to connect with people. That's incredibly important. I think you got to have some thick skin, and you certainly have to understand how and when to pick and choose your battles. You can't fight every battle. Every battle is not worth fighting; otherwise, you run yourself into the ground. You've got to be able to understand and devise a system that helps you identify, which of those battles are truly worth fighting. You must have a sense of humor.

We have to support one another. I think it's unfortunate that sometimes, still, despite how few of us there are, there's still this perception sometimes of competition. There's not enough of us to be able to afford to be sabotaging one another or not supporting one another. So, we've got to learn to support one another and view our successes as collectives. I'm a firm believer that we share our successes and our failures.

Martin. You're already enough regardless of what it is that you have on the inside. You just have to find ways to manifest it. Know how to have a thick skin with a soft heart, and also, 
know how to just display yourself as human in the midst of those who may discount your humanity. You have to get away from allowing anybody else's attitude to determine the altitude at which we fly. And if you feel as though you're in a dead end space or whatever you're doing, which I do not, maybe it's time to concentrate on how to own said spaces or create said spaces rather than trying to fit into spaces that have been defined for who we are.

\section{Conclusion}

The purpose of this study was to unmask the anti-black lived experiences of nine Black administrators at HWIs. This qualitative study used critical ethnography to conduct in-depth interviews and field observations. As the researcher who aspires to be a Black senior-level administrator, this study gave me the agency and wisdom needed to navigate HWIs. I am humbled and reaffirmed in knowing it is possible to be unapologetically Black while successfully leading in higher education. Through the shared experiences narrated by the participants, an insightful understanding of the complexities of Black men in HWIs was created.

This study contributes to the existing literature regarding Black administrators. The two themes, anti-blackness and Blackness, that emerged from this study provided a blueprint for aspiring Black administrators. Sundown institutions, personal sacrifice, and work twice as hard were the sub-themes derived from anti-blackness; Black and proud, Wakanda, and hiding in plain sight were the sub-themes derived from Blackness. The themes and sub-themes epitomized the ways Black administrators processed, navigated, and made meaning of their lived experiences. I hope this study becomes a source of strength, liberation, and healing for Black men in higher education. This study was unapologetically rooted in Blackness and the results proved Blackness is the cure for anti-blackness. By using the strategies unmasked in this study, Black administrators at HWIs are uniquely positioned to be Black while leading and disrupting 
the pervasiveness of anti-black lived experiences. 


\section{REFERENCES}

Abdul-Jabbar, K. (2020, May 30). Don't understand the protests? What you're seeing is people pushed to the edge. Los Angeles Times. Retrieved from https://www.latimes.com /opinion/story/2020-05-30/don't-understand-the-protests-what-youre-seeing-is-peoplepushed-to-the-edge

Allen, E., Jr. (1997). On the reading of riddles: Rethinking DuBoisian double consciousness. In L. R. Gordon (Ed.), Existence in black: An anthology of black existential philosophy (pp. 49-68). New York, NY: Routledge.

American Association of University Professors. (1915). Appendix I: 1915 Declaration of principles on academic freedom and academic freedom. https://www.aaup.org/NR /rdonlyres/A6520A9D-0A9A-47B3-B550-C006B5B224E7/0/1915Declaration.pdf.

Anderson, C. (1997). Dirty little secrets about black history: Its heroes \& other troublemakers. Bethesda, MD: PowerNomics Corporation of America.

Anderson, G. L. (1989). Critical ethnography in education: Origins, current status, and new directions. Review of Educational Research, 59(3), 249-270.

Anderson, T. (1988). Black encounter of racism and elitism in white academe: A critique of the system. Journal of Black Studies, 18(3), 259-272.

Angle, P. M., Lincoln, A., \& Douglas, S. A. (1958). Created equal: The complete LincolnDouglas debates of 1858. Chicago, IL: University of Chicago Press.

Baldwin, J. (1993). The fire next time. New York, NY: Vintage International.

Banks, J. A. (1998). The lives and values of researchers: Implications for educating citizens in a multicultural society. Educational Researcher, 27(7), 4-17. 
Bell, D. (1992a). Faces at the bottom of the well: The permanence of racism. New York, NY: Basic Books.

Bell, D. (1992b). Racial realism. Connecticut Law Review, 24(2), 363-379.

Bichsel, J., \& McChesney, J. (2017, March). Pay and representation of racial/ethnic minorities in higher education administrative positions: The century so far. Research report. CUPAHR. Retrieved from https://www.cupahr.org/surveys/briefs.aspx

Bloomberg, L. D., \& Volpe, M. (2019). Completing your qualitative dissertation: A road map from beginning to end (4th ed.). Los Angeles, CA: SAGE.

Bolling, J. R., Brewer, K., \& Griesbach, R. (2019, September). Dean of students resigns after pictures of past tweets. The Crimson White. Retrieved from https://cw.ua.edu/54140/topstories/breaking-dean-of-students-allegedly-resigns-after-pictures-of-past-tweets-surface/

Bolman, L. G., \& Deal, T. E. (2017). Reframing organizations: Artistry, choice and leadership (6th ed.). Hoboken, NJ: Jossey-Bass.

Bor, J., Venkataramani, A., Williams, D., \& Tsai, A. (2018). Police killings and their spillover effects on the mental health of black americans: A population-based, quasi-experimental study. The Lancet, 392(10144), 302-310.

Boyd, M. J. (2004). The African American presence and the resolution of race in the matrix trilogy. Black Renaissance/Renaissance Noire, 5, 129+. Retrieved from https://link.gale.com/apps/doc/A123366228/LitRC?u=chic_rbw\&sid=LitRC\&xid=a1c47 $8 \mathrm{~b} 3$

Brooks, J. S., \& Arnold, N. W. (2013). Confronting racism in higher education: Problems and possibilities for fighting ignorance, bigotry and isolation. Charlotte, NC: Information Age. 
Brown v. Board of Education, 347 U.S. 483 (1954)

Browne, S. (2015). Dark matters: On the surveillance of blackness. Durham, NC: Duke University Press.

Caldwell, L. D., \& Stewart, J. B. (2001). Rethinking W.E.B. DuBois' double consciousness. In L. Jones (Ed.), Retaining African Americans in higher education: Challenging paradigms for retaining students, faculty, and administrators (1st ed., pp. 225-234). Sterling, VA: Stylus.

Carnevale, A. P., \& Strohl, J. (2013). Separate \& unequal: How higher education reinforces the intergenerational reproduction of White racial privilege. Retrieved from https://vtechworks.lib.vt.edu/bitstream/handle/10919/83041/SeparateandUnequal.pdf?seq uence $=1 \&$ is Allowed $=\mathrm{y}$

Carter, S. (2017). Kill Jay Z . On 4:44 [Album]. New York, NY: Roc Nation.

Coates, T. (2012). Fear of a black president. The Atlantic. Retrieved from https://www.theatlantic.com/magazine/archive/2012/09/fear-of-a-blackpresident/309064/

Coates, T. (2014). Kim Novak's bid to be twice as good. The Atlantic. Retrieved from https://www.theatlantic.com/entertainment/archive/2014/03/kim-novaks-bid-to-be-twiceas-good/284194/

Comer, J. P. (1978). The black public school administrator: Understanding and reducing administrative stress. In S. L. Woodard (Ed.), Reducing stress on black administrators (1st ed., pp. 1-11). New York, NY: Vantage Press.

Curry, T. J. (2017). The man-not: Race, class, genre, and the dilemmas of black manhood. Philadelphia, PA: Temple University Press. 
Dancy, T. E., II, Edwards, K. T., \& Earl Davis, J. (2018). Historically white universities and plantation politics: Anti-blackness and higher education in the black lives matter era. Urban Education, 53(2), 176-195.

Davis, J. D. (1994). Coloring the halls of ivy: Leadership \& diversity in the academy. Bolton, MA: Anker.

Dei, G. J. S. (2017). Reframing blackness and black solidarities through anti-colonial and decolonial prisms. Cham: Springer International.

Dei, G. J. S. (2018). Black like me: Reframing blackness for decolonial politics. Journal of the American Educational Studies Association, 54(2), 117-142.

Delgado, R., \& Stefancic, J. (2017). Critical race theory: An introduction (3rd ed.). New York, NY: New York University Press.

DuBois, W. E. B. (1897). Striving for the negro people. Atlantic Monthly, 80, 194-198.

DuBois, W. E. B. (1906). Conference for the study of the Negro Problems Atlanta. The health and physique of the Negro American: Report of a social study made under the direction of Atlanta University, together with the proceedings of the eleventh Conference for the Study of the Negro Problems, held at Atlanta University. Atlanta, GA: Atlanta University Press.

Dugas, S. N. (2002). Chronology of an African American administrator: The high level mammy. In M. Taylor-Archer \& S. Smith (Eds.), Our stories: The experiences of black professionals on predominantly white campuses (pp. 79-90). Cincinnati, OH: John D. O'Bryant Think Tank.

Dumas, M. (2014). Losing an arm: Schooling as a site of black suffering. Race, Ethnicity, and Education, 17(1), 1-29. 
Dumas, M. J. (2016). Against the dark: Anti-blackness in education policy and discourse. Theory Into Practice, 55(1), 11-19.

Dumas, M. J. (2018). Beginning and ending with black suffering: A meditation on and against racial justice in education. In E. Tuck \& K. W. Yang (Eds.), Towards what justice? Describing diverse dreams of justice in education (pp. 29-45). New York, NY: Routledge.

Dumas, M. J., \& Nelson, J. D. (2016). (Re)Imagining black boyhood: Toward a critical framework for educational research. Harvard Educational Review, 86(1), 27-47.

Dumas, M. J., \& Ross, K. M. (2016). Be real black for me: Imagining BlackCrit in education. Urban Education, 51(4), 415-442.

Durgans, K. B. (2002). Evolution of a college administrator or maintaining one's cultural integrity while working on a predominantly white campus. In M. Taylor-Archer \& S. Smith (Eds.), Our stories: The experiences of black professionals on predominantly white campuses (pp. 31-45). Cincinnati, OH: John D. O'Bryant Think Tank.

Fanon, F., \& Philcox, R. (2008). Black skin, white masks. New York, NY: Grove Press.

Feagin, J. R. (2001). Racist America: Roots, current realities, and future reparations. The AAG Review of Books, 3(1), 14-15. htpps://doi.org/10.1080/2325548X.2015.985530

Feige, K. (Producer), \& Coogler, R. (Director). (2018). Black Panther [Motion picture]. United States. Marvel Studios.

Glaude, E. S. (2016). Democracy in black: How race still enslaves the American soul. New York, NY: Crown.

Glesne, C. (2011). Becoming qualitative researchers: An introduction (4th ed.). Boston, MA: Pearson. 
Goff, P. A., Jackson, M. C., Di Leone, B. A. L., Culotta, C. M., \& DiTomasso, N. A. (2014). The essence of innocence: Consequences of dehumanizing black children. Journal of Personality and Social Psychology, 106(4), 526-545.

Gordon, L. R. (1997). Existence in black: An anthology of black existential philosophy. New York, NY: Routledge.

Grant, C. A., Woodson, A., \& Dumas, M. (2019). The future is black: Afropessimism, fugitivity, and radical hope in education. New York, NY: Routledge.

Griswold v. Connecticut, 381 U.S. 479, (1965)

Guillory, R. M. (2001). Strategies for overcoming the barriers of being an African American administrator on a predominantly white university campus. In L. Jones (Ed.), Retaining African Americans in higher education: Challenging paradigms for retaining students, faculty, and administrators (1st ed., pp. 111-124). Sterling, VA: Stylus.

Hale, F. W., Jr. (1975). A sprinkle of pepper: The state of black influence in white colleges and universities. Journal of Non-White Concerns in Personnel and Guidance, 3(2), 45-52.

Hammonds, M. D. (2012). Onward and upward: Characteristics of African American senior student affairs officers. Theses and Dissertations Retrieved from https://scholarworks .uark.edu/etd/478

Hart, W. D. (2018). Constellations: Capitalism, anti-blackness, afro-pessimism, and black optimism. American Journal of Theology \& Philosophy, 39(1), 5-33.

Hartman, S. V. (1997). Scenes of subjection: Terror, slavery, and self-making in nineteenthcentury America. New York, NY: Oxford University Press.

Hartman, S. V. (2007). Lose your mother: A journey along the Atlantic slave route. New York, NY: Farrar, Straus, and Giroux. 
Hartman, S. V. (2017, July 28). The terrible beauty of the slum. Brick, 99. Retrieved from https://brickmag.com/the-terrible-beauty-of-the-slum/

Harvey, W. B. (1999). Grass roots and glass ceilings: African American administrators in predominantly white colleges and universities. Albany, NY: State University of New York Press.

Henderson, G. (2010). Race and the university: A memoir. Norman, OK: University of Oklahoma Press.

Hester, J. (2020). The battlefield of the academy: The resilience and resistance of black women faculty. (Unpublished doctoral dissertation). Illinois State University, Normal, IL.

Hicks, T., \& Watson, L. (2018). Black administrators in higher education: Autoethnographic explorations and personal narratives. Lanham, MD: Rowman \& Littlefield.

Hill, G., Arndt, S.,Wachowski, L., Tykwer, T., \& Wachowski, L. (Producers) \& Wachowski, L., Tykwer, T., \& Wachowski, L. (Directors). (2012). Cloud Atlas [Motion picture]. United States: Warner Bros.

Hoff, P. T. (2020). Picked to pieces: The cost of opportunity. In Y. F. Neimann, G. G. Y. Muhs, \& C. G. Gonzalez (Eds.), Presumed incompetent II: Race, class, power, and resistance of women in academia (pp. 39-48). Boulder, CO: Utah State University Press.

Hooks, B. (1990). Yearning: Race, gender, and cultural politics. Boston, MA: South End Press. Hoskins, R. L. (1978). Black administrators in higher education: Conditions and perceptions. New York, NY: Praeger.

Hunter, D. (2016). I flunked Sambo University. Lexington, KY: Author. 
Jackson, J. F. L. (2001). A new test for diversity: Retaining African American administrators at predominantly white institutions. In L. Jones (Ed.), Retaining African Americans in higher education: Challenging paradigms for retaining students, faculty, and administrators (1st ed., pp. 93-110). Sterling, VA: Stylus.

Jackson, J. F. L., \& Flowers, L. A. (2003). Retaining African American student affairs administrators: Voices from the field. College Student Affairs Journal, 22(2), 125-136.

Jaffe, L. (2019). The legend of A-N-N-A: Revisiting an American town where black people weren't welcome after dark. ProPublica Illinois. Retrieved from https://features .propublica.org/illinois-sundown-towns/legend-of-anna/

Johnson, S. (2019). Curriculum of the mind: A Blackcrit, narrative inquiry, hip hop album on anti-blackness and freedom for black-male collegians at historically white institutions. (Unpublished doctoral dissertation). University of Oklahoma, Norman, OK.

Jones, L. (2001). Retaining African Americans in higher education: Challenging paradigms for retaining students, faculty, and administrators (1st ed.). Sterling, VA: Stylus.

Jones, L. (2018, September 24). USC race center issues report card on black student equity. Diverse: Issues in higher education. Retrieved from https://diverseeducation.com /article/127419

Judson, H. (1999). A meaningful contribution. In W. B. Harvey (Ed.), Grass roots and glass ceilings: African American administrators in predominantly white colleges and universities (pp. 83-111). Albany, NY: State University of New York Press.

Lee, H., \& Hicken, M. T. (2016). Death by a thousand cuts: The health implications of black respectability politics. Souls, 18(2-4), 421-445. doi:10.1080/10999949.2016.1230828 
Lee, S., \& Worth, M. (Producers), \& Lee, S. (Director). (1992). Malcolm X [Motion picture]. United States: Warner Bros. \& Largo International.

Lewis, G. L. (2007, Spring). African-American male senior administrators in predominantly white institutions: A study on resilience. (Doctoral dissertation). Retrieved from https://digitalcommons.georgiasouthern.edu/etd/204

Litwack, L. (2004). From hellbounds. In N. Scheper-Hughes \& P. I. Bourgois (Eds.), Violence in war and peace (pp. 123-128). Malden, MA: Blackwell.

Loewen, J. W. (2018). Sundown towns: A hidden dimension of American racism. New York, NY: The New Press.

Kahn, K. B., \& McMahon, J. M. (2015). Shooting deaths of unarmed racial minorities: Understanding the role of racial stereotypes on decisions to shoot. Translational Issues in Psychological Science, 1(4), 310-320. doi:10.1037/tps0000047

Kendi, I. X. (2016). Stamped from the beginning: The definitive history of racist ideas in America. New York, NY: Nation Books.

Kendi, I. X. (2019). How to be an antiracist. New York, NY: One World.

King, T. L. (2016). The labor of (re)reading plantation landscapes fungible(ly). Antipode, 48(4), 1022-1039. doi:10.1111/anti.12227

Kirkwood, A. M. (2018). Maintaining one's consciousness: An exploratory study of upper-level black community college administrators as racially conscious leaders. (Doctoral dissertation). Retrieved from ProQuest Dissertations and Theses database. (UMI No. 10843405)

Madison, D. S. (2020). Critical ethnography: Method, ethics, and performance (3rd ed.). Los Angeles, CA: SAGE. 
Mbembe, A., \& Corcoran, S. (2019). Necropolitics. Durham, NC: Duke University Press.

Melaku, T. M., \& Beeman, A. (2020). Academia isn't a safe haven for conversations about race and racism. Harvard Business Review. Retrieved from https://hbr.org/2020/06/academiaisnt-a-safe-haven-for-conversations-about-race-and-racism

Mendoza, M. (2004, November 9). Father Healy's imprint: Past, present and future. The Hoya Newsletter Georgetown University. Retrieved from https://thehoya.com/father-healysimprint-past-present-and-future/

Mills, C. W. (1997). The racial contract. Ithaca, NY: Cornell University Press.

Mitchell, P. A. (2017). African American males in higher education leadership: Challenges and opportunities. New York, NY: Peter Lang.

Moore, W., \& Wagstaff, L. H. (1974). Black educators in white colleges. San Francisco, CA: Jossey-Bass.

MSNBC (Producer). (2020, May 2). Coronavirus outcomes worse for people of color as states reopen [Television series episode]. AM Joy. Retrieved from https://www.msnbc.com/amjoy/watch/coronavirus-outcomes-worse-for-people-of-color-as-states-reopen82945093590

Muhammad, K. G. (2019). The condemnation of blackness: Race, crime, and the making of modern urban america. Cambridge, MA: Harvard University Press.

Mustaffa, J. B. (2017). Mapping violence, naming life: A history of anti-back oppression in the higher education system. International Journal of Qualitative Studies in Education, 30(8), 711-727. 
Nelms, C. (1999). From cotton picker to university CEO. In W. B. Harvey (Ed.), Grass roots and glass ceilings: African American administrators in predominantly white colleges and universities (pp. 39-56). Albany, NY: State University of New York Press.

Newton, J. (2017). Anti-black racism, resistance, and the health and well-being of black bodies in public education. In J. Newton \& A. Soltani (Eds.), New framings on anti-racism and resistance: Resistance and the new futurity. Rotterdam, Netherlands: Sense. https://doi.org/10.1007/978-94-6351-131-5_4

Oliver, B., \& Davis, J. D. (1994). Things they don't teach you about being a dean. In J. D. Davis (Ed.), Coloring the halls of ivy: Leadership \& diversity in the academy (pp. 59-70). Bolton, MA: Anker.

O'Toole, J. M. (2002). Passing for white: Race, religion, and the Healy family, 1820-1920. Amherst, MA: University of Massachusetts Press.

Ore, E. J. (2016). Pushback: A pedagogy of care. Pedagogy, 17(1), 9-33.

Ore, E. J. (2019). Lynching: Violence, rhetoric, and american identity. Jackson, MS: University of Mississippi Press.

Parker, L. (2019). Who let the dogs in? Anti-blackness, social exclusion, and the question of who is human. Journal of Black Studies, 50(4), 367-387.

Patterson, O. (2018). Slavery and social death: A comparative study. Cambridge, MA: Harvard University Press.

Peiterse, A., \& Powell, S. (2016). A theoretical overview of the impact of racism on people of color. In A. N. Alvarez, C. T. H. Liang, \& H. A. Neville (Eds.), The cost of racism for people of color: Contextualizing experiences of discrimination (1st ed., pp. 11-30). Washington, DC: American Psychological Association. 
Perry, J. C., \& Pickett, L. L. (2016). The costs of racism on workforce entry and workplace adjustment. In A. N. Alvarez, C. T. H. Liang, \& H. A. Neville (Eds.), The cost of racism for people of color: Contextualizing experiences of discrimination (1st ed., pp. 203-227). Washington, DC: American Psychological Association.

Pickron, C. (1991). The experience of black male administrators at predominantly white fouryear institutions of higher education. (Doctoral dissertation). Retrieved from ProQuest Dissertations and Theses database. (UMI No. 9132895)

Pinderhughes, E. (1989). Understanding race, ethnicity, and power: The key to efficacy in clinical practice. New York, NY: Free Press.

Rhodes, D. (2019). Western Illinois University president steps down. Chicago Tribune. Retrieved from https://www.chicagotribune.com/news/breaking/ct-met-western-illinoisuniversity-president-resigns-20190614-story.html

Riley, J. (2020). Student affairs is not safe for Black/African American people. [An open letter to student affairs]. Medium. Retrieved from https://medium.com/@jrriley03_68478/anopen-letter-to-student-affa9irs-student-affairs-is-not-safe-for-black-african-americanpeople-4421e5b40bdf

Robertson, H., \& Travaglia, J. (2020). The necropolitics of COVID-19: Will the COVID-19 pandemic reshape national healthcare systems? Retrieved from https://blogs.1se.ac.uk/ impactofsocialsciences/2020/05/18/the-necroplitics-of-covid-19-will-the-covid-19pandemic-reshape-national-healthcare-systems/

Rollins, D. (2017). Navigating racism in higher education: A grounded theory study of black male administrators. (Doctoral dissertation). ProQuest Dissertations and Theses database. (UMI No. 10270066) 
Ross, K. M. (2019). On black education: Anti-blackness, refusal, and resistance. In C. A. Grant, A. Woodson, \& M. Dumas (Eds.), The future is black: Afropessimism, fugitivity, and radical hope in education. New York, NY: Routledge.

Ross, K. M. (2020). Call it what it is: Anti-blackness. The New York Times. Retrieved from https://nyti.ms/3eJ60ry

Saldaña, J. (2016). The coding manual for qualitative researchers (3rd ed.). Los Angeles, CA: SAGE.

Saraiya, S. (2020, July/August). Viola Davis: My entire life has been a protest. Vanity Fair. Retrieved from https:/www.vanityfair.com/hollywood/2020/07/cover-story-viola-davis

Schlossberg, N. K. (1989, Winter). Marginality and mattering: Key issues in building community. New Directions for Student Services, 48, 5-15.

Scott, D. (2016). The career trajectory of black male presidents at predominantly white institutions. (Doctoral dissertation). Retrieved from ProQuest Dissertations and Theses database. (UMI No. 10133660)

Seawood, L. (2005). A study of perceptions about racism and influential effects on satisfaction and the retention of African American student affairs administrators in traditionally white institutions of higher education. (Doctoral dissertation). Retrieved from ProQuest Dissertations and Theses database. (UMI No. 3233921)

Seltzer, R. (2017). Failing to keep up. Inside Higher Education. Retrieved from https://www.insidehighered.com/news/2017/03/02/racial-gap-among-senioradministrators-widens 
Serwer, A. (2020). The coronavirus was an emergency until Trump found out who was dying. The Atlantic. Retrieved from https://www.theatlanticom/ideas/archive/2020/05/americasracial-contract-showing/611389/

Sexton, J. (2011, Fall/Winter). The social life of social death: On Afro-pessimism and black optimism. InTensions, 5(1).

Sexton, J. (2017). Black masculinity and the cinema of policing. New York, NY: Macmillian.

Sharpe, C. E. (2016). In the wake: On blackness and being. Durham, NC: Duke University Press.

Silver, J. (Producer), \& Wachowski, L., \& Wachowski, L. (Directors). (1999). The Matrix [Motion picture]. United States: Warner Bros., Village Roadshow, Silver Pictures. Simmons, S. (2017). One man's journey. In P. A. Mitchell (Ed.), African American males in higher education leadership: Challenges and opportunities (pp. 117-142). New York, NY: Peter Lang.

Smiley, C., \& Fakunle, D. (2016). From brute to thug: The demonization and criminalization of unarmed black male victims in America. Journal of Human Behavior in the Social Environment, 26(3-4), 350-366. doi:10.1080/10911359.2015.1129256

Smith, C. H. (1980). The peculiar status of black-educational administrators: The university setting. Journal of Black Studies, 10(3), 323-334.

Smith, W. A., Hung, M., \& Franklin, J. D. (2011). Racial battle fatigue and the miseducation of black men: Racial microaggressions, societal problems, and environmental stress. Journal of Negro Education, 80(1), 63-82. 
Smith, W. A., Mustaffa, J. B., Jones, C. M., Curry, T. J., \& Allen, W. R. (2016). You make me wanna holler and throw up both my hands: Campus culture, black misandric microaggressions, and racial battle fatigue. International Journal of Qualitative Studies in Education, 29(9), 1189-1209.

Snowden, F. M. (1991). Before color prejudice: The ancient view of blacks. Cambridge, MA: Harvard University Press.

Stokes, M. (2011). The career paths of African American male senior administrators in student affairs at predominantly white institutions: Formal and informal leadership experiences (Doctoral dissertation). Retrieved from https://opensiuc.lib.siu.edu/dissertations/326/

Strayhorn, T. L. (2012). College students' sense of belonging: A key to educational success for all students. New York, NY: Routledge.

Stripling, J. (2019, Nov. 8). Fear of a black campus: How an ugly campaign to force out an African American president exposed racial fault lines in a mostly white town. Chronicle of Higher Education, 66(10), A12. Retrieved from https://proxy.uchicago.edu/login? url=http://search.ebscohost.com/ login. aspx direct $=$ true $\& d b=$ edsbro $\& A N=$ edsbro.A609856829\&site $=$ eds-live $\&$ scope $=$ site Sweezy v. New Hampshire, 354 U.S. 234 (1957)

Taylor, K.-Y. (2016). From \#BlackLivesMatter to black liberation. Chicago, IL: Haymarket Books.

The Chronicle of Higher Education. (2018a). Characteristics of recipients of research doctorates, FY 2016. The Almanac of Higher Education. Retreived from https://store.chronicle.com/products/the-almanac-of-higher-education-2018 
The Chronicle of Higher Education. (2018b). Managers in higher education, by gender, race, and ethnicity, Fall 2013 and Fall 2016. The Almanac of Higher Education. Retreived from https://store.chronicle.com/products/the-almanac-of-higher-education-2018

The National Museum of African American History and Culture. (2019). Popular and pervasive stereotypes of African Americans. Retrieved from https://nmaahc.si.edu/blogpost/popular-and-pervasive-stereotypes-african-americans

Thelin, J. R. (2011). A history of american higher education (2nd ed.). Baltimore, MD: John Hopkins University Press.

Thelin, J. R. (2014). Essential documents in the history of american higher education. Baltimore, MD: John Hopkins University Press.

Thomas, J. (2015). Within these gates: Academic work, academic leadership, university life, and the Presidency. Lanham, MD: University Press of America

Thompson, R. (2016). Examining perceptions of black administrators in higher education regarding administrative leadership opportunities. UNF Graduate Theses and Dissertations. 713. Retrieved from https://digitalcommons.unf.edu/etd/713

United States. (1944). Servicemen's readjustment act of 1944. Public law 346, chapter 268, S. 1767. Washington, DC: Government Printing Office.

Valverde, L. A. (2003). Leaders of color in higher education: Unrecognized triumphs in harsh institutions. Walnut Creek, CA: AltaMira Press.

Vargas, J. H. C. (2018). The denial of anti-blackness: Multiracial redemption and black suffering. Minneapolis, MN: University of Minnesota Press. 
Venzant Chambers, T. T., \& Huggins, K. S. (2014). The influence of school factors on racial opportunity cost for high-achieving students of color. Journal of School Leadership, 24(1), 189-225.

Washington, H. A. (2006). Medical apartheid: The dark history of medical experimentation on Black Americans from colonial times to the present. New York, NY: Anchor Books.

Watts-Jones, D. (202). Healing internalized racism: The role of within-group sanctuary among people of African descent. Family Process, 41(4), 591-601.

Welsing, F. C. (1991). The isis papers: The keys to the colors. Washington, DC: C. W. Publishing.

White House Historical Association. (n.d.). Slavery and the white house. Retrieved from https://www.whitehousehistory.org/press-room/press-fact-sheets/slavery-and-the-whitehouse

White, J. (1970, September). Toward a black psychology: White theories ignore ghetto life styles. Ebony Magazine, 25(11), 45-52.

Wilder, C. S. (2013). Ebony \& ivy: Race, slavery, and the troubled history of america's universities. New York, NY: Bloomsbury Press.

Wilderson, F. B. (2010). Red, white \& black: Cinema and the structure of U.S. antagonisms. Durham, NC: Duke University Press.

Wilderson, F. B. (2020). Afropessimism. New York, NY: Liveright.

Wiley, J. W. (2001). Retaining African American administrators: A subconscious deluge of neglect or a conscious subterfuge to reject? In L. Jones (Ed.), Retaining African Americans in higher education: Challenging paradigms for retaining students, faculty, and administrators (1st ed., pp. 125-146). Sterling, VA: Stylus. 
Williams, D. A. (2013). Strategic diversity leadership. Sterling, VA: Stylus.

Winkle-Wagner, R., Lee-Johnson, J., \& Gaskew, A. (2019). Critical theory and qualitative data analysis in education. New York, NY: Routledge.

Wolfe, B. L. (2010). When being black isn't enough: Experiences and persistence strategies of six African American administrators at a PWI. (Unpublished doctoral dissertation). Auburn University, Auburn, Alabama.

Wolfe, B. L. (2013). Persistence is chess, not checkers: A counterstory on the lives and strategies of six African American administrators at one predominantly white institution. In J. S. Brooks \& N. W. Arnold (Eds.), Confronting racism in higher education: Problems and possibilities for fighting ignorance, bigotry and isolation (pp. 21-41). Charlotte, NC: Information Age.

Wolfe, B. L., \& Dilworth, P. P. (2015). Transitioning normalcy: Organizational culture, African American administrators, and diversity leadership in higher education. Review of Educational Research, 85(4), 667-697.

Woodard, M. C., \& Harris, C. W. (1978). Administrative stress: Viewed from the perspective of the black administrator. In S. L. Woodard (Ed.), Reducing stress on black administrators (1st ed., pp. 13-35). New York, NY: Vantage Press.

Woodard, S. L. (1978). Reducing stress on black administrators (1st ed.). New York, NY: Vantage Press.

Woods, T. P. (2019). Blackhood against the police power: Punishment and disavowal in the post-racial era. East Lansing, MI: Michigan State University Press. 
Woodson, A. (2019). Afropessimism for us in education. In C. A. Grant, A. Woodson, \& M. Dumas (Eds.), The future is black: Afropessimism, fugitivity, and radical hope in education (pp. 16-21). New York, NY: Routledge.

Woodson, C. G. (2011). The mis-education of the negro. New York, NY: Tribeca Books.

Wright, D., Taylor, J. D., Burrell, C., \& Stewart, G. (2006). African American administrators and staff. Metropolitan Universities, 17(2), 58-68.

Wright, M. M. (2015). Physics of blackness: Beyond the middle passage epistemology. Minneapolis, MN: University of Minnesota Press.

Ziyad, H., \& DuWhite, T. (2019). Anti-blackness is equilibrium: How disparity logics pathologize black male bodies and render other black bodies invisible. In C. A. Grant, A. Woodson, \& M. Dumas (Eds.), The future is black: Afropessimism, fugitivity, and radical hope in education. New York, NY: Routledge. 


\section{APPENDIX A: EMAIL LETTER FOR PARTICIPANT NOMINATION}

Dear

My name is DuJuan Smith and I am a doctoral candidate under the direction of Dr. Pamela Twyman Hoff in the Department of Educational Administration and Foundations (EAF) at Illinois State University (ISU). I am conducting a research study to explore the lived experiences of senior-level Black male Administrators at Historically White Institutions (HWIs). I am conducting this study to finish my educational requirements for my terminal degree in Higher Education Administration. Participation will involve a 60-90 minute interview, which will be audio recorded, and a one-day campus observation.

Prospective research participants must meet the entire list of the following criterion:

1. Must identify as a Black or of African descent;

2. Must identify as a man;

3. Must currently work at a four-year HWI in a senior-level position such as President/Chancellor, Vice President, Associate/Assistant Vice President, Provost, Dean, \& Department Chair. These administrative leaders are in academic affairs and/or student affairs; and

4. Must have seven years of progressive experience in higher education.

This study uses the snowballing sampling technique; I am requesting your assistance in identifying prospective participants for this groundbreaking study. Based on the criterion outlined above, if you know a senior-level Black male administrator at a HWI, please forward me their name, email address, and phone number. 
Participation in this study is voluntary and participates have the right to withdraw at any time. This study will not include any identifiable information of participants. All participants will be asked to create a pseudonym that they will be referred to as for the entire study. The campus site will be protected and referred to by pseudonym.

I value your time and considerations and eagerly await your nominations for prospective participants. I am requesting your nomination, sent directly to desmit2@ilstu.edu, by [DATE]. If you have any questions concerning the research study, please contact me at 773-XXX-XXXX. You may also contact my Dissertation Chair, Dr. Pamela Twyman Hoff at 3XX-XXX-XXXX or via email at phoff@ilstu.edu.

Sincerely,

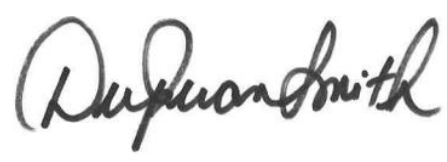

Doctoral Student

Illinois State University 


\section{APPENDIX B: EMAIL LETTER TO PROSPECTIVE PARTICIPANT}

Dear

My name is DuJuan Smith and I am a doctoral candidate under the direction of Dr. Pamela Twyman Hoff in the Department of Educational Administration and Foundations (EAF) at Illinois State University (ISU). You are receiving this correspondence because you were nominated by [NOMINATOR'S NAME]. I am conducting a research study to explore the lived experiences of senior-level Black male Administrators at Historically White Institutions (HWIs). I am conducting this study to finish my educational requirements for my terminal degree in Higher Education Administration. Your participation will involve a 60-90 minute interview, which will be audio recorded, and a one-day campus observation.

Prospective participants must meet the entire list of the following criterion:

1. Must identify as a Black or of African descent;

2. Must identify as a man;

3. Must currently work at a four-year HWI in a senior-level position such as President/Chancellor, Vice President, Associate/Assistant Vice President, Provost, Dean, \& Department Chair. These administrative leaders are in academic affairs and/or student affairs; and

4. Must have seven years of progressive experience in higher education.

Based on the criterion outlined above, you have been identified by [NOMINATOR'S NAME] as an ideal candidate; therefore, I would like to invite you to be a participant in my study.

Participation in this study is voluntary and you have the right to withdraw at any time. This study will not include any of your identifiable information. You will be asked to create a pseudonym 
that they will be referred to as for the entire study. Your campus site will be protected and referred to by pseudonym.

I value your time and considerations and eagerly await your decision to participate in this study. I am requesting your decision, sent directly to desmit2@ilstu.edu, by [DATE]. If you have any questions concerning the research study, please contact me at 773-XXX-XXXX. You may also contact my Dissertation Chair, Dr. Pamela Twyman Hoff at XX9-XXX-XXXX or via email at phoff@ilstu.edu.

Sincerely,

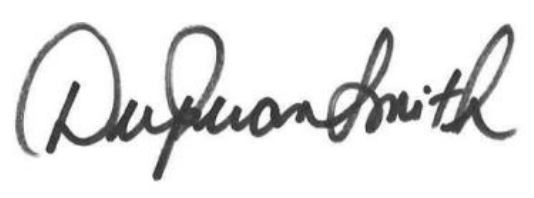

DuJuan Smith

Doctoral Student

Illinois State University 


\section{APPENDIX C: PARTICIPANT CONSENT FORM}

\section{BLACK WHILE LEADING: UNMASKING THE ANTI-BLACK LIVED EXPERIENCES OF SENIOR-LEVEL BLACK MEN ADMINISTRATORS AT HISTORICALLY WHITE INSTITUTIONS}

You are being asked to participate in a research study conducted by DuJuan Smith, a doctoral student, under the direction of Dr. Pamela Twyman Hoff, the Principal Investigator, in the Department of Educational Administration and Foundations (EAF) at Illinois State University. The purpose of this study is to gain a deeper understanding of how senior-level Black men administrators' process, navigate, and make meaning of their lived experiences at Historically White Institutions (HWIs).

\section{WHY ARE YOU BEING ASKED?}

You have been asked to participate because you were nominated by a fellow professional colleague as a potentially ideal candidate for this study. You currently serve in a senior-level leadership position as a Black man administrator at a HWI with seven or more years of progressive experience in higher education. Your participation in this study is voluntary. You will not be penalized if you choose to skip parts of the study, not participate, or withdraw from the study at any time.

\section{WHAT WOULD YOU DO?}

If you choose to participate in this study, you will participate in a 60-90 minute interview on your respective campus. Your interview will be audio-recorded. You also will allow me to shadow you for about $4-6$ hours during the remainder of your workday. Furthermore, you will refer me to a colleague on your campus who can speak to observing you in action within the confines of your role as a senior-level Black administrator at a HWI.

You will be asked to provide a pseudonym for you and your respective campus. If I am unsure whether information you provide is appropriate for my official field notes, I will ask your permission. This information will be used throughout the interview and final write up to protect your identity. In total, your involvement in this study will last approximately eight hours (one full workday).

\section{ARE ANY RISKS EXPECTED?}

The risks associated with this research are no greater than those encountered in their lives every day. You may be asked to recall memories that may be painful or difficult to express. To reduce these risks, we will remind you of your right to stop participation in the research at any time or at any point in the process without any repercussions. There is also a risk of employability and reputation in the event of a confidentiality breach; however, all data collected will use pseudonyms and no identifiable information will be recorded or captured to mitigate the risk. You will be reminded of how we will mitigate any risk of confidentiality. To mitigate the risk of a confidentiality breach, only the Principal Investigators will have password-protected access to the data. All audio recordings, transcribed interviews, and notes will be stored on 
password- protected computer. In the final write-up of the study direct quotes will be used, however, all identifying information will be stripped from the responses and pseudonyms will be used.

\section{WILL YOUR INFORMATION BE PROTECTED?}

We will use all reasonable efforts to keep any provided personal information confidential. No personal identifiable information or location markers will be used in this study. All data will be kept on a university issued password-protected laptop that only the Principal Investigator and I will be able to access. Furthermore, your consent form will be kept in a locked file cabinet in the Principal Investigator's office. Information that may identify you or potentially lead to reidentification will not be released to individuals that are not on the research team. The final write-up will have direct quotes given by the participants. Pseudonyms will be used to protect the participants' identities, and identity markers will be stripped. The results of this research may be presented at public symposiums or conferences, published in journals, and used to develop training materials for professional higher education institutions for professionals.

However, when required by law or university policy, identifying information (including your signed consent form) may be seen or copied by authorized individuals.

\section{COULD YOUR RESPONSES BE USED FOR OTHER RESEARCH?}

We will not use any identifiable information from you in future research, but your deidentified information could be used for future research without additional consent from you.

\section{WHO WILL BENEFIT FROM THIS STUDY?}

Though there are no direct benefits to you for your participation in this study, your participation will make a significant contribution to the limited existing literature on Black administrators in higher education. This study is providing you with a unique opportunity to reflect on your lived experiences in higher education in a meaningful way. In addition, you will be given a platform to share your lessons learned in order to help create change for how senior-level Black men administrators are viewed and treated. Furthermore, your participation in the groundbreaking research will help inform future presentations, higher education leadership pipeline programs, and policy development for institutions recruiting Black administrators.

\section{WHOM DO YOU CONTACT IF YOU HAVE ANY OUESTIONS?}

If you have any questions about the research or wish to withdraw from the study, contact me at 773-XXX-XXXX or desmit2@ilstu.edu. You may also contact the Principal Investigator, Dr. Pamela Twyman Hoff, at 3XX-XXX-XXXX or via email at phoff@ilstu.edu.

If you have any questions about your rights as a participant, or if you feel you have been placed at risk, contact the Illinois State University Research Ethics \& Compliance Office at (309) 
XXX-XXXX or IRB@ilstu.edu.

DOCUMENTATION OF CONSENT

Sign below if you are 18 or older and willing to participate in this study.

Signature

Date

You will be given a copy of this form for your records. 


\section{APPENDIX D: REFERRED COLLEAGUE PARTICIPANT CONSENT}

\section{BLACK WHILE LEADING: UNMASKING THE ANTI-BLACK LIVED EXPERIENCES OF SENIOR-LEVEL BLACK MEN ADMINISTRATORS AT HISTORICALLY WHITE INSTITUTIONS}

You are being asked to participate in a research study conducted by DuJuan Smith, a doctoral student, under the direction of Dr. Pamela Twyman Hoff, the Principal Investigator, in the Department of Educational Administration and Foundations (EAF) at Illinois State University. The purpose of this study is to gain a deeper understanding of how senior-level Black men administrators' process, navigate, and make meaning of their lived experiences at Historically White Institutions (HWIs).

\section{WHY ARE YOU BEING ASKED?}

You have been asked to participate through a referral from a participant in this study. You were identified because the participant believes you would be the best professional colleague to speak to your experience and observation of the participant in action in his role as a seniorlevel Black man administrator at a HWI. Your participation in this study is voluntary. You will not be penalized if you choose to skip parts of the study, not participate, or withdraw from the study at any time.

\section{WHAT WOULD YOU DO?}

If you choose to participate in this study, you will participate in a 30 minute interview on your respective campus. Your interview will be audio-recorded. You will be asked to provide a pseudonym to protect your identity. In addition, your campus and the participant will also have pseudonyms, which will be shared with you prior to the start of the interview. All of the pseudonyms provided will be used in the final write up to protect everyone's respective identities. In total, your involvement in this study will last approximately 30 minutes.

\section{ARE ANY RISKS EXPECTED?}

The risks associated with this research are no greater than those encountered in their lives every day. You may be asked to recall memories that may be painful or difficult to express. To reduce these risks, we will remind you of your right to stop participation in the research at any time or at any point in the process without any repercussions. There is also a risk of employability and reputation in the event of a confidentiality breach; however, all data collected will use pseudonyms and no identifiable information will be recorded or captured to mitigate the risk.

You will be reminded of how we will mitigate any risk of confidentiality. To mitigate the risk of a confidentiality breach, only the Principal Investigator and I will have password-protected access to the data. All audio recordings, transcribed interviews, and notes will be stored on password-protected computer. In the final write-up of the study direct quotes will be used, however, all identifying information will be stripped from the responses and pseudonyms will be used. 


\section{WILL YOUR INFORMATION BE PROTECTED?}

We will use all reasonable efforts to keep any provided personal information confidential. No personal identifiable information or location markers will be used in this study. All data will be kept on a university issued password-protected laptop that only the Principal Investigator and I will be able to access. Furthermore, your consent form will be kept in a locked file cabinet in the Principal Investigator's office. Information that may identify you or potentially lead to reidentification will not be released to individuals that are not on the research team. The final write-up will have direct quotes given by the participants. Pseudonyms will be used to protect the participants' identities, and identity markers will be stripped. The results of this research may be presented at public symposiums or conferences, published in journals, and used to develop training materials for professional higher education institutions for professionals.

However, when required by law or university policy, identifying information (including your signed consent form) may be seen or copied by authorized individuals.

\section{COULD YOUR RESPONSES BE USED FOR OTHER RESEARCH?}

We will not use any identifiable information from you in future research, but your deidentified information could be used for future research without additional consent from you.

\section{WHO WILL BENEFIT FROM THIS STUDY?}

Though there are no direct benefits to you for your participation in this study, your participation will make a significant contribution to the limited existing literature on Black administrators in higher education. This study is providing you with a unique opportunity to reflect on the lived experiences of your colleague, the participant, in higher education in a meaningful way. In addition, you are supporting the participant in using this platform to share his lessons learned in order to help create change for how senior-level Black men administrators are viewed and treated. Furthermore, your participation in this groundbreaking research will help inform future presentations, higher education leadership pipeline programs, and policy development for institutions recruiting Black administrators.

\section{WHOM DO YOU CONTACT IF YOU HAVE ANY QUESTIONS?}

If you have any questions about the research or wish to withdraw from the study, contact me at 773-XXX-XXXX or desmit2@ilstu.edu. You may also contact the Principal Investigator, Dr. Pamela Twyman Hoff, at 3XX-XXX-XXXX or via email at phoff@ilstu.edu.

If you have any questions about your rights as a participant, or if you feel you have been placed at risk, contact the Illinois State University Research Ethics \& Compliance Office at (309) XXX-XXXX or IRB@ilstu.edu. 
DOCUMENTATION OF CONSENT

Sign below if you are 18 or older and willing to participate in this study.

Signature

Date

You will be given a copy of this form for your records 


\section{APPENDIX E: INTERVIEW QUESTIONS}

Article Reflection

1. What reactions do you have? What resonated the most with you about this article?

2. Did any aspect of this article surprise you?

3. How do you think the impacts of racial discrimination are affecting Black folks in administration at HWIs?

4. As a Black senior-level administrator at an HWI, what are your takeaways from the situation described in the article?

\section{Blackness}

1. How has your Black identity (or Blackness) impacted your life? If you are struggling to answer the question, why?

2. Tell me about any early/first memories you have of learning positive things about Blackness and Black people (from family, media, friends, teachers, etc.)

3. What about any early/first memories you have of learning negatives things about Blackness and Black people (from family, media, friends, teachers, etc.)

4. How do those early messages still inform your thoughts, feelings, or actions today?

5. What led you to pursue leadership in higher education?

6. What personal values or beliefs guide how you show up as a leader in this position?

7. Can you tell me about any experiences you have had where your position expectations were in direct conflict with your espoused values or beliefs?

8. Describe for me how you believe others may perceive you as a Black leader in this position at this HWI? Please elaborate.

9. In what ways, if any, does your Black identity inform how you see and navigate the dynamics of your role? How about senior administration leadership? If so, how so? 
10. What barriers do you think contribute to the racial inequalities in senior-level administration leadership at HWIs?

Affirmations (A) \& Marginalization (M)

1. What does a typical day look and feel like in your role? What about your tough or bad days?

2. Who or what serves as your source(s) of personal support and/or professional counsel? (A)

3. In what ways are you affirmed and/or celebrated for the work that you do in this position? (A)

4. Tell me about the challenges, if any, that you have faced as a Black senior-level administrator. (M)

5. There is an expression that goes, "you think you know but you have no idea." What is something that you believe people would be surprised to know about the lived experience of your role. (M)

6. What sacrifices, if any, have you made in order to be at this point in your career? In other words, what have you had to lose to gain your current positionality? (M)

7. How do you decompress from and cope with the stress of your work? (A)

8. Have you ever considered leaving higher education because of any of the challenges you have faced? If so, what factors led to your decision to stay in the field? (M)

9. What factors do you feel have had the greatest impact on your longevity and advancement in higher education? (A) 
10. What attributes, learned or innate, do you think are important for aspiring Black men administrators to possess if they want to become senior-level administrators in higher education? (A)

11. What do you want your legacy to be? (A)

12. Understanding the purpose of this study, is there anything you would like to add? 


\title{
APPENDIX F: PREINTERVIEW ARTICLE
}

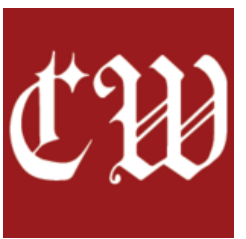

\section{BREAKING: Dean of students resigns after pictures of past tweets surface}

\author{
Photo courtesy of UA News
}

\section{Jessa Reid Bolling | @jr_bolling, Keely Brewer | @keelykbrewer, and Rebecca Griesbach | @rebach97}

Jamie R. Riley, the University of Alabama's assistant vice president and dean of students, resigned from his position on Thursday after less than seven months on the job, UA officials confirmed.

His resignation comes a day after Breitbart News published an article detailing images of past tweets from Riley, in which he criticized the American flag and made a connection between police and racism.

Jackson Fuentes, press secretary for the UA Student Government Association, confirmed at 4:15 p.m. that Riley is no longer working at the University.

"For us right now, basically all I can tell you is that the University and Dr. Riley have mutually agreed to part ways," Fuentes said. "So yeah, that's true, and we do wish him the best."

In an email at 5:03 p.m., assistant director of the Division of Strategic Communications Chris Bryant released an official statement on behalf of the University confirming Riley's resignation.

"Dr. Jamie Riley has resigned his position at The University of Alabama by mutual agreement," Bryant said in the email. "Neither party will have any further comments."

Breitbart News has a reputation for being an ultra-conservative news, opinion and commentary website. The article reads that the author reached out to the University last week to receive a comment on Riley's past tweets but that a statement was not given. The article also says Riley's Twitter account appeared as private on Friday morning so only his followers could view his account. 


\section{Jamie R. Riley, PhD}

@jrriley03

\section{The flag represents a systemic} history of racism for my people. Police are a part of that system. Is it that hard to see the correlation?

\section{6:25 AM · 9/26/17 - Twitter for iPhone}

"The [American flag emoji] flag represents a systemic history of racism for my people," Riley wrote in the tweet. "Police are a part of that system. Is it that hard to see the correlation?"

In a separate image of a tweet in October 2017, Riley said white people have "0 opinion" on racism because white people cannot experience racism.

'I'm baffled about how the first thing white people say is, 'That's not racist!' when they can't even experience racism," Riley wrote in the tweet. "You have 0 opinion!" 


\section{Jamie R. Riley, PhD}

@jrriley03

\section{I'm baffled about how the 1st thing}

white people say is ,"That's not racist!"

when they can't even experience

racism? You have 0 opinion!

11:24 PM - 10/11/17 - Twitter for iPhone

4 Likes
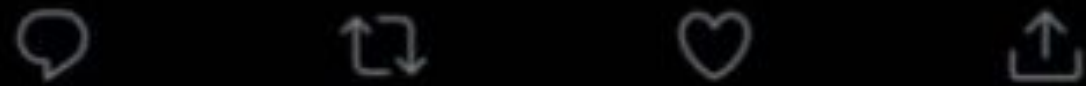

Jamie R. Riley, PhD @jrrile... ·10/11/17 \#missmewithyourprivilege
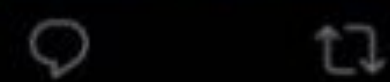

$\mathrm{O}_{3}$

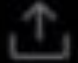

Under the previous tweet, Riley sent a hashtag that read “\#missmewithyourprivilege.” Later, an image of a 2016 tweet from Riley shows him questioning the motive of making movies about slavery. 


\section{Jamie R. Riley, PhD}

@jrriley03

\section{Are movies about slavery truly about}

\section{educating the unaware, or to remind}

\section{Black people of our place in society?}

\section{2:29 AM $\cdot 10 / 8 / 16 \cdot$ Twitter for iPhone}

"Are movies about slavery truly about educating the unaware, or to remind Black people of our place in society," Riley wrote.

Riley was named to the position on Dec. 13, 2018 after a national search and he began serving on Feb. 25, 2019. Before gaining the position at the University of Alabama, Riley served as the executive director and chief operating officer of Alpha Phi Alpha Fraternity, Inc. He also served in student affairs and diversity and inclusion roles at institutions including Johns Hopkins University, The University of California-Berkeley and Morehouse College.

As of Thursday, Riley's Twitter account appears to have been deleted, thus The Crimson White was unable to confirm if the tweets were from his account.

Fox News host Laura Ingraham tweeted the story this morning, gaining 252 replies, 253 retweets and over 430 likes as of Thursday evening. 


\section{Laura Ingraham 0 @ingrahamAngle·9h}

Torments from the Twitter Attic: University of Alabama Dean Claimed American Flag, Police are Racist

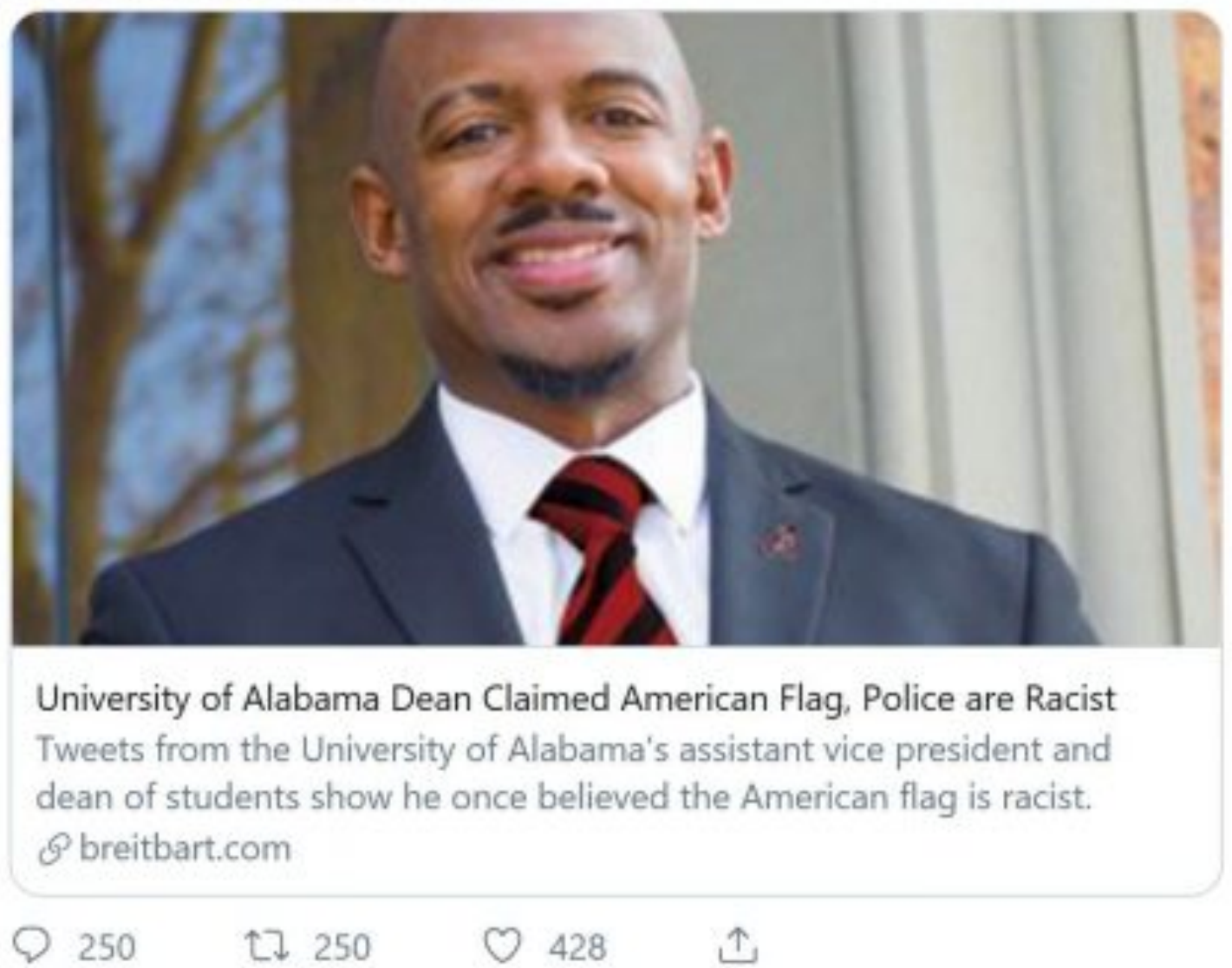

As of Thursday evening, Riley's UA contact information was removed from the UA dean of students webpage and his LinkedIn account was deactivated.

Steven Hood, associate vice president of student life, stated in an email at 5:59 p.m. that "Dr. Jamie Riley has resigned his position at The University of Alabama by mutual agreement. Neither the university or Dr. Riley will have any further comments."

The Crimson White submitted a Freedom of Information Act (FOIA) request to officials in the division of strategic communications on Thursday at 6:47 p.m. regarding any recent contracts or emails detailing Riley's resignation. This story will be updated as it develops.

UPDATE Thursday, Sept. 5 at 9:15 p.m. Tweets from Riley's deleted Twitter account have been recovered, confirming that he did send the tweets mentioned in the Breitbart article.

This story was updated on Sept. 6 at 2 p.m. 
UPDATE Friday, Sept. 6 at 5:04 p.m. Unite for Reproductive \& Gender Equity (URGE) UA, a sexual and reproductive justice advocacy student organization at the University of Alabama, released a statement at 12:45 p.m. on Friday regarding the recent resignation of former assistant vice president and dean of students, Jamie R. Riley.

“As URGE UA is affiliated with the University of Alabama, we would like to make a statement on a recent occurrence at the University.

This Thursday, Sept. 5, Dr. Jamie R. Riley, the University of Alabama's Assistant Vice President and Dean of Students for the past six months, resigned from his position. This decision is said to have been "mutually agreed" upon by both Dr. Riley and the University. Dr. Riley's resignation follows the surface of past Tweets concerning systematic racism in America.

URGE UA is deeply saddened to see Dr. Riley leave the University, as he was always extremely supportive of our mission every time he interacted with our organization. His views and experience as a black man working at a predominantly white institution were incredibly valuable to the University of Alabama; we are extremely disappointed that the University led him to feel that resigning was the best decision.

The University of Alabama has shown various times that it encourages its students and faculty to exercise their freedom of speech; however, this situation seems to be a contradiction to those occurrences.

URGE UA encourages students to speak out on their opinions and not back down in the face of opposition; we do not stand for injustice, and we will not be silent about any sort of wrongdoing at UA.

URGE UA wishes Dr. Riley the best in all his future endeavors and encourages him to not stop speaking out on his beliefs."

Note. From "Dean of students allegedly resigns after pictures of past tweets surface," by J. R. Bolling, K. Brewer, \& R. Griesbach, (2019, September), The Crimson White Retrieved from https://cw.ua.edu/54140/top-stories/breaking-dean-of-students-allegedly-resigns-after-picturesof-past-tweets-surface/ 